\author{
UNIVERSIDADE DE SÃO PAULO \\ ESCOLA DE COMUNICAÇÕES E ARTES \\ PROGRAMA DE PÓS-GRADUAÇÃo EM CIÊNCIA DA IINFORMAÇÃo
}

Sônia Barreto de Novaes Paschoal

\title{
MEDIAÇÃO CULTURAL DIALÓGICA COM CRIANÇAS E ADOLESCENTES: \\ oficinas de leitura e singularização
}

São Paulo

2009 


\section{SÔNIA BARRETO DE NOVAES PASCHOAL}

\section{MEDIAÇÃO CULTURAL DIALÓGICA COM CRIANÇAS E ADOLESCENTES: \\ oficinas de leitura e singularização}

Dissertação apresentada à Escola de Comunicações e Artes, da Universidade de São Paulo, para a obtenção do título de Mestre em Ciência da Informação.

Área de Concentração: Cultura e Informação Linha de Pesquisa: Mediação e Ação Cultural.

Orientador: Prof. Dr. Edmir Perrotti

SÃO PAULO

2009 
Catalogação na Publicação

P285 PASCHOAL, Sônia Barreto de Novaes

Mediação cultural dialógica com crianças e adolescentes: oficinas de leitura e singularização. / Sônia Barreto de Novaes Paschoal; orientação Prof. Dr. Edmir Perrotti. São Paulo: ECA/USP, 2009.

103 f.; il.

Dissertação (Mestrado - Programa de Pós-Graduação em Ciência da Informação. Área de concentração: Informação e Cultura). - Escola de Comunicações e Artes da Universidade de São Paulo.

1. Ciência da Informação 2. Infoeducação 3. Mediação Cultural Dialógica 4. Crianças e Adolescentes 5. Abrigo 6. Oficinas de Leitura 7. Singularização 8. Metodologia Colaborativa I. Título II. Perrotti, Edmir, orient. 
PASCHOAL, Sonia Barreto de Novaes

Mediação cultural dialógica com crianças e adolescentes: oficinas de leitura e singularização

Dissertação apresentada ao Curso de Pós-Graduação, em Ciência da Informação, da Escola de Comunicações e Artes, da Universidade de São Paulo, como exigência parcial para a obtenção do título de Mestre em Ciência da Informação, sob a orientação do Prof. Dr. Edmir Perrotti.

Aprovado em:

\section{Banca}

Prof. Dr. Edmir Perrotti (Orientador) 
Primeiramente o conhecimento: é na contemplação de um face-a-face, que o ser se revela a quem o quer conhecer. Martin Buber

When I came home I expected a surprise And there was no surprise for me, so, of course, I was surprised. Ludwig Wittgenstein 
Ao Ian,

presente inesperado, surpreendência singular em minha vida.

Ao Nathan, presente esperado, surpreendência singular em minha vida. 


\section{AGRADECIMENTOS}

Ao Mauro e à Dinalva, meus pais, por me ensinarem a verdadeira graça do e pelo mundo.

Ao Rubens, por me ver em tempos e espaços próprios e por apoiar todas as minhas decisões.

Aos meus filhos, pela espera e questionamento:

- Mãe, quando isso vai acabar?

Ao meu querido mestre professor Edmir Perrotti, por orientar de maneira singular esses meus vôos, ora altos, ora rasos.

Ao professor Gilson Schwartz, pela não-finalizabilidade ao nortear caminhos e trilhas do conhecimento e do saber.

Aos amigos do ColaborI, pela presentidade em todos os momentos de enfrentamentos com as teorias e compartilhamento de práticas.

À Lucimara, pela colaboração e apontamentos sobre o que é e como poderia ser o Abrigo.

À Samara, amiga que me surpreende com seu protagonismo.

À CAPES, pela bolsa de pesquisa. 


\section{RESUMO}

Esta dissertação é um estudo exploratório sobre o conceito de mediação cultural dialógica realizado a partir de oficinas de leitura comprometidas com o protagonismo cultural de crianças e adolescentes (00 a 18 anos) em situação de abrigo numa cidade do interior paulista a cerca de 80 kilômetros da capital. A metodologia utilizada foi a da pesquisa colaborativa e os dados foram analisados por meio das seguintes categorias: ambientes, ações, tempos, protagonistas e polifonia. Os resultados indicam que as mediações culturais realizadas no abrigo, centradas na singularização de crianças e jovens, foram capazes de romper com a impessoalidade, a frieza e a monotonia que marcam diversos aspectos da vida nos abrigos. Resistentes no início, à medida que as oficinas de leitura se desenvolviam e ganhavam corpo na dialogia todos os protagonistas (crianças, adolescentes, monitores e o próprio pesquisador) se reconheciam como parte destas ações, apropriando-se delas segundo suas expectativas e interesses específicos, criando vínculos com o mediador e com os livros, relacionando as leituras com outras atividades e práticas culturais, mostrando-se aptos a ressignificar $\mathrm{o}$ ato de ler. A mediação cultural dialógica, ao propiciar a singularização dessas crianças e jovens, permitiu a emergência de valores e significados para textos e contextos, para leitores e mediadores que se apresentaram como protagonistas culturais, categoria centrada no encontro e na vinculação com o outro.

Palavras-chave: infoeducação; mediação cultural dialógica; oficinas de leitura; protagonismo cultural; singularização; abrigo; crianças e adolescentes; metodologia colaborativa. 


\begin{abstract}
This dissertation is an exploratory study of the concept of dialogical cultural mediation focused on reading skills workshops for the cultural protagonism of children and teenagers ( 0 to 18$)$ at a shelter (in a city 80 kilometers from São Paulo). A collaborative research methodology was used so that data could be analyzed framed by the following categories: environments, actions, time, actors and polyphony. Results indicate that cultural mediations rooted in the singularization of children and teenagers empower them to break away from impersonal, cold and monotonous disciplinary practices. Resistant at first, all actors then engaged and enthused as the workshops were developed and reading became part of a dialogue among children, teenagers, instructors and the researcher herself. Actions could then be adapted to their expectations and specific interests, creating links with the mediator so as to connect elements in the books and readings with other cultural practices and activities. The act of reading was infused with new meanings as dialogical cultural mediation facilitated the singularization of children and teenagers. Readers and mediators became cultural protagonists - a category founded on the encounter with the other.
\end{abstract}

Keywords: infoeducation; dialogical cultural mediation; reading workshops; cultural protagonism; singularization; shelter; children and teenagers; collaborative methodology. 


\section{Sumário}

Introdução

Apresentação 1

Objeto e Objetivos 2

a) Objetivos gerais $\quad 2$

b) Objetivos específicos 3

Histórico: o percurso e a interrogação 4

Justificativa: Por que Mediação Cultural Dialógica 12

$\begin{array}{ll}\text { Organização do trabalho } & 15\end{array}$

\section{Parte A: Conceitos}

1. $\mathrm{O}$ conceito de mediação cultural dialógica 17

$\begin{array}{lll}1.1 & \text { Aspectos da mediação } & 20\end{array}$

1.2 Mediação e dispositivos $\quad 22$

$\begin{array}{lll}\text { 1.2.1 O mediador } & 23\end{array}$

$\begin{array}{lll}\text { 1.2.2 } & \text { Mediação e Midiatização } & 24\end{array}$

1.3 Mediação e vinculação 26

2. O conceito de cultura 30

$2.1 \quad$ A leitura 33

2.2 Leitura e dispositivos: a oficina de leitura 36

3. $\mathbf{O}$ conceito de dialogia 37

$\begin{array}{lll}3.1 & \text { Protagonismo cultural } & 40\end{array}$

4. $\mathrm{O}$ conceito de abrigo 41 


\section{Parte B: Metodologia}

1. A metodologia colaborativa 48

2. Abrigo "Lar provisório" 5

\section{PARTE C: A Pesquisa}

1. A mala pronta para viagens a bordo da leitura 56

2. Os ambientes 62

2.1 O Abrigo 63

$\begin{array}{lll}2.2 & \text { A Biblioteca } & 67\end{array}$

2.3 O Carro $\quad 69$

$\begin{array}{lll}2.4 & \text { Outros ambientes } & 71\end{array}$

3. As Práticas Culturais: as oficinas de leitura 74

4. O tempo 82

$4.1 \quad$ Tempo Institucional $\quad 83$

$\begin{array}{lll}4.2 & \text { Tempo Pessoal } & 84\end{array}$

5. Os protagonistas $\quad 85$

5.1 As crianças e os adolescentes $\quad 85$

$\begin{array}{lll}5.2 & \text { Os mediadores } & 87\end{array}$

$\begin{array}{lll}\text { 5.2.1 A Assistente Social, as psicólogas e as monitoras do Abrigo } & 87\end{array}$

5.1.2 Os Mediadores de leitura da Biblioteca Pública 89

$\begin{array}{lll}\text { 5.1.3 O mediador/pesquisador } & 91\end{array}$

$\begin{array}{ll}\text { 6. A polifonia } & 92\end{array}$ 
Considerações finais:

Dialogia e a singularização

Referências

Anexos 


\section{Introdução}

\section{Apresentação}

A realização de oficinas de leitura com crianças e adolescentes em situação de abrigo $^{1}$, ao longo de três anos, em duas cidades do interior paulista, revelou um universo até então desconhecido por mim. A complexidade da situação levou-me a inquietações tanto de ordem profissional como pessoal: de um lado, colocavam-se as múltiplas ausências que marcam a vida de crianças e adolescentes em situação de abrigo; de outro, a beleza permanente de uma infância querendo dar e receber afetos e que, independentemente das circunstâncias a que estão sujeitas, atuam e sabem inventar seus brinquedos, expressam e comunicam vontades, sonhos e desejos, às vezes de formas dificilmente compreensíveis, outras, espontâneas e simples, como é comum entre as crianças de qualquer tempo e lugar.

Como profissional da área da informação e da cultura, meu contato ocorreu em trabalho motivado por questões implicadas nas mediações entre os repertórios culturais de diferentes públicos. Tais questionamentos me acompanham desde a graduação. Aquelas oficinas tinham em vista, portanto, a compreensão e a atuação profissional, comprometida com a participação afirmativa do público nos processos simbólicos. A infância e a juventude eram, pois, um recorte especial de uma questão teórica e metodológica que vinha me acompanhando e que então se voltava, para um público com o qual sempre tive afinidades especiais.

Este trabalho apresenta um estudo exploratório sobre as relações entre o conceito de mediação cultural dialógica e as situações concretas vividas em abrigos no interior de São Paulo, a partir da realização de oficinas de leitura com crianças e jovens. Conceitos-chave como mediação, cultura e dialogia, articulados entre si, resultam numa formulação dotada de sentido próprio e que nos serviu de referência. Esperamos que, num movimento dialógico, nossos resultados possam também alimentar os próprios conceitos, descortinando novos panoramas até então pouco explorados. Nesse sentido, o abrigo é um campo privilegiado de análise para pensar questões que envolvem não

\footnotetext{
${ }^{1} \mathrm{Na}$ área social e jurídica a expressão criança e adolescente em situação de abrigo refere-se àqueles que estão em caráter provisório e excepcional em abrigos, esse considerados pelo ECA como "[...] forma de transição para a colocação em família substituta, não implicando privação de liberdade.” (BRASIL, 1998)
} 
apenas as crianças e jovens que lá se encontram, mas também amplos quadros sociais contemporâneos, marcados por exclusões de todos os tipos, decorrentes de lógicas sociais pautadas pela massificação e indiferenciação.

O trabalho insere-se no quadro de pesquisas do ColaborI - Colaboratório de Infoeducação $^{2}$, voltado a estudos que delimitam um novo objeto de estudo, a Infoeducação, envolvendo os processos contemporâneos de apropriação social da informação, em suas relações dinâmicas e inextricáveis com as questões educacionais e culturais. Utiliza-se de metodologia colaborativa como forma de construção de conhecimentos, nos termos definidos por Perrotti (2007).

O caminho da colaboratividade impôs-se, também, como necessidade do próprio objeto, pois interagir, escutar suas vozes, compartilhar e trocar significados com os múltiplos sujeitos em situações concretas e reais era condição fundamental aos objetivos deste estudo, fundamentado no conceito de dialogia, categoria distintiva, capaz de conferir qualidades criativas aos atos de mediação cultural.

\section{Objeto e Objetivos}

Este trabalho tem por objeto teórico o estudo do conceito de mediação cultural dialógica, a partir da realização de oficinas de leituras com crianças e adolescentes em situação de abrigo, com os seguintes objetivos:

\section{A) Objetivo Geral}

Contribuir para a compreensão e o avanço do conceito de mediação cultural dialógica, categoria teórica e metodológica necessária ao desenvolvimento e à consolidação da Infoeducação enquanto abordagem das relações entre Informação e Educação, compatível com princípios de protagonização cultural.

\section{B) Objetivos Específicos}

\footnotetext{
${ }^{2}$ A Infoeducação é uma "[...] área de estudo, situada nos desvãos das Ciências da Informação e da Educação, voltada à compreensão das conexões existentes entre apropriação simbólica e dispositivos culturais, como condição à sistematização de referências teóricas e metodológicas necessárias ao desenvolvimento dinâmico e articulado de aprendizagens e de dispositivos informacionais [...]" (PERROTTI, 2007, p. 92).
} 
a) Sistematizar referências metodológicas necessárias ao desenvolvimento de Oficinas de leitura pautadas por princípios dialógicos;

b) Contribuir para o desenvolvimento de práticas de leitura em abrigos e possibilitar experiências culturais significativas às crianças e aos jovens em situação de abrigo, permitindo-lhes apropriar-se de saberes informacionais fundamentais à construção de conhecimentos e à articipação afirmativa na cultura. 


\title{
Histórico: um percurso à interrogação
}

\author{
Para que cada ser cresça e produza, é preciso o tempo certo, \\ um prazo concreto, seu prazo individual. \\ Gaston Bachelard
}

Desde os seis anos de idade, moro em Atibaia, a $65 \mathrm{~km}$ da cidade de São Paulo. Quando estudante de Biblioteconomia, as minhas viagens diárias Atibaia-USP-Atibaia apresentavam-se como momentos propícios a reflexões de toda ordem. Uma delas era recorrente. Mesmo querendo livrar-me de, sua onipresença desafiadora, envolvendo o ato de conhecer, não conseguia: "O que faz com que tantas pessoas, inclusive eu, saíam de seus mundos para conhecer outros? A necessidade? A curiosidade? O conhecimento em si pode mudar alguma coisa nos cotidianos das pessoas ou nas próprias pessoas? $\mathrm{O}$ que leva uma pessoa a buscar informações, em geral, ou então, uma determinada informação? O que faz com que pessoas, independentemente da sua idade, se apeguem ou desconsiderem as informações que receberam?"

O que terão feito aqueles companheiros da primeira série da Isolada da Chácara Brasil $^{3}$, com as experiências e saberes que compartilhamos, com as vivências acumuladas e os castigos que tanto temíamos? Lembro que, muitas vezes, tínhamos que arrancar a folha do caderno com a lição mal feita, amassar e ficar com ela na boca, sem engolir...! Recordo também o velho castigo de ficar virado para as paredes... "Por onde andará aquele menino que não conseguia manter o papel na boca e acabava por engolir a lição? Será que a rigidez metodológica foi um caminho adequado ou estará o então menino, até hoje, com dificuldades para 'digerir' as informações?”

O ônibus fazia seu percurso alheio às minhas inquietações e eu também ia a outros caminhos que aquele ônibus não podia percorrer. Minha imaginação abria janelas que estavam além da paisagem oferecida pela rodovia Fernão Dias. Janelas plurais, janelas diversas que me levam a pensar no jogo contido na marca do sistema operacional Windows. Quereriam seus criadores colocar em comparação as janelas concretas e as virtuais? O destino das informações estaria ligado à natureza das janelas?

\footnotetext{
${ }^{3}$ Escola situada em zona rural do município de Atibaia de primeira a quarta série, hoje equivalente ao primeiro ciclo do ensino fundamental.
} 
Se o interesse pela busca de informações e conhecimento me mobilizava, levando-me a percorrer diariamente o trecho entre Atibaia e a USP, por outro lado, me inquietava, também. Sabia que algumas pessoas, ao não conseguirem realizar suas buscas de informação, abandonavam seus projetos de conhecimento, algumas inclusive evitando questões difíceis, por medo de novos fracassos. Que relações existiriam entre conhecer e agir, entre informar-se e formar-se, entre saber e interagir, acertar e errar? Simples? Complexas? De exclusão, de complementação?

Não acreditava que um conhecimento alimentasse automaticamente o desejo de novos conhecimentos, embora soubesse que uma pergunta é sempre uma janela para outra. Assim, ia divagando sobre as razões de algumas pessoas não abrirem mão do desejo de conhecer, de outras aceitarem o papel de eternos coadjuvantes e de outras ainda, ao menos aparentemente, matarem suas curiosidades e interesses aceitando o mundo pronto e dado.

A viagem diária e concreta era também a oportunidade para uma viagem de outra natureza, simbólica, situada no tempo da imaginação e da reflexão; de encontros e de conversas com outras pessoas, além de solilóquios e monólogos que me ajudavam a vencer os 85 quilômetros que separavam a minha casa da Universidade. Mal sabia que a distância abria caminhos dos quais eu sequer suspeitava.

Fui bolsista de iniciação científica do CNPq. Vinculei-me, assim, ao PROESI Programa Serviço de Informação em Educação -, coordenado pelo Prof. Dr. Edmir Perrotti. Meu intuito era compreender melhor a razão de estudar Biblioteconomia e, principalmente, aprender como se faz pesquisa científica. A pesquisa era uma forma de alimentar meu desejo de saber que necessitava ser nutrido, era passaporte que fortalecia minha identidade de viajante nas estradas do conhecimento. A iniciação científica, as aulas e as vivências na Universidade imprimiam novas marcas em mim. Mas uma insatisfação me acompanhava como estudante que não compreendia ainda as relações entre procedimentos bibliotecários que me eram ensinados e inquietações sobre o sentido das informações e dos conhecimentos. Afinal, qual era o sentido social da minha profissão e o significado existencial do bibliotecário?

O pensamento é algo realmente ambíguo: brota em incessantes e infinitos partos, isto é, provoca dor e prazer. Se conhecer é impulso vital, necessidade, energia objetivada em símbolos e signos que nos mobilizam e renovam em sentidos nunca estáticos, como compreender aqueles espaços que o curso me apresentava: bibliotecas, centros culturais, museus - se suas concepções e práticas não se articulavam e 
integravam com o desejo de conhecimento da maioria das pessoas que os frequentavam?

Com esses questionamentos, já preocupada com públicos ausentes desses espaços de cultura, escrevi o trabalho de conclusão de curso intitulado "Percepção visual $e$ cinestésica do adolescente no espaço da biblioteca pública", constatando a ausência ou a inoperância da maioria desses espaços para a juventude. A preocupação vinha da disciplina Metodologia de iniciação científica, quando realizamos uma pesquisa sobre comunicação visual no Centro Cultural São Paulo. Nessa pesquisa observamos que tal comunicação não atingia sua finalidade, principalmente com o grupo de jovens, e que o CCSP não funcionava como um centro, um local onde as pessoas realizavam diversas atividades. $\mathrm{O}$ que se observou foi pessoas freqüentando o Centro residualmente, não aproveitando nem se relacionando com sua diversidade. Quem ia à biblioteca, não ia ao cinema, ao teatro ou às exposições; quem freqüentava os shows não usava os demais recursos disponíveis.

Em outras disciplinas era claro que os museus, as bibliotecas e outros espaços consagrados à Cultura e às Artes não atingiam plenamente os públicos que almejavam. Apesar de alguns desses espaços já atentarem para questões educativas (museus que adotavam programas sistemáticos de arte-educação), transparecia uma visão míope da arte e da cultura bastando-se por si mesmas, sem que a completude das obras se realizasse no olhar dos seus espectadores, ainda que não imediatamente.

O fato é que, ao término da faculdade, me vi desafiada pelas minhas viagens reais e imaginárias. Trazia comigo um projeto realizado para a disciplina "Planejamento Bibliotecário I e II" e o apresentei à Prefeitura do Município de Piracaia, que na época não o acolheu. Um ano se passou, outro prefeito foi eleito e resolvi reapresentar o projeto. Um dia depois da posse da nova Administração, fui chamada para o quadro de comissionados da Secretaria de Cultura, como responsável pela Divisão de Bibliotecas.

Quantas bibliotecas havia nesse município? Concretamente, naquele momento, nenhuma. Devido à interdição do prédio, todo acervo e mobiliário da biblioteca foram para o Departamento de Obras da Prefeitura. Não era Biblioteca, sob nenhum pretexto.

Mas o chão de Piracaia é mesmo de pedra, como diz seu brasão ${ }^{4}$ - a duras penas, a Biblioteca foi aparecendo. Comecei pela triagem do acervo, onde me deparei com raridades e com um acervo voltado para as artes. Da triagem, alguns livros foram

\footnotetext{
${ }^{4}$ No brasão de Piracaia: "Minhas pedras são predestinadas."
} 
vendidos e muitos outros descartados ${ }^{5}$, o que levou um vereador a me chamar de louca: “Onde já se viu? Vá lá Prefeito, a sua bibliotecária ficou louca! Imagina jogar livros fora quando tantas pessoas precisam!" Enfim, enquanto a Biblioteca passava por uma metamorfose, conseguimos trazer duas exposições itinerantes para a cidade, por meio do "Sistema de Bibliotecas do Estado de São Paulo". Uma delas, "A História da Ópera", causou impactos na cidade, contra e a favor. Alguns professores locais diziam: "Você tem que fazer o que interessa para o público. Como assim ópera? E lá eles querem ópera? Eles querem lambada!" Eu respondia: "Eu não vou oferecer às pessoas só o que elas já têm! É preciso abrir caminhos para novas possibilidades. Nesse caso, utilizando as ferramentas que o Estado e o Municipio disponibilizam."

A necessidade de encontrar parceiros para essa empreitada dinamizou um processo que envolveu vários setores, não só da Prefeitura como da sociedade como um todo. Daí, já ia percebendo o quanto são necessários os elos, as afinidades, os apoios. Das muitas conjeturas que foram surgindo, umas iam se confirmando e outras não. Assumi então a Divisão de Cultura, oportunidade para ampliar os trabalhos. Fizemos algumas exposições, as "Rodas de Histórias Ecológicas" continuavam no Parque Ecológico. Alguns amigos iam se fazendo e outros se perdendo, por conta da política a que o jogo cultural obriga. Naquele ano, a Administração Municipal foi homenageada com o primeiro Prêmio Laura Russo, oferecido pelo Conselho Regional de Biblioteconomia aos prefeitos que mais fizeram pelas suas bibliotecas públicas.

Apesar das mobilizações e dos avanços, por razões particulares, entreguei meu cargo e decidi que eu seria apenas mãe e dona de casa. Decisão que não durou muito. Fui chamada para trabalhar numa faculdade particular de Atibaia. Não era minha opção, tinha um preconceito em relação a certas instituições particulares de ensino superior. Levei um currículo incompleto, na tentativa de não ser aceita e disse que só poderia trabalhar ali por 20 horas semanais (meio período). O Diretor não teve dúvidas, me contratou nas condições que eu havia estabelecido, pois estava interessado em minha formação na USP - uma grife que agregava valor à Instituição que dirigia.

Ressurgiu então a questão do ambiente da biblioteca, que havia acabado de ser reformada. Sua porta de entrada era próxima à da cantina. Os alunos chegavam com seus lanches, falando sem distinguir os ambientes. Fui obrigada a trabalhar no sentido de formar e orientar atitudes nesse ambiente. Outra questão era a necessidade do

\footnotetext{
${ }^{5}$ Esses livros não apresentavam a menor condição de uso, muitos estavam mofados, rasgados, faltando páginas, etc.
} 
usuário saber se relacionar com o espaço e acessar as informações que lhe convinham. Eu pensava que a biblioteca deveria oferecer mais. Então, a partir de algumas reuniões com a diretoria, com professores e alguns alunos, foi estabelecida uma agenda cultural. Foram realizadas oficinas literárias (leituras, filmes, palestras e idas a teatros em São Paulo), a Semana da Consciência Negra, entre outros programas. Toda agenda cultural era pensada de forma orgânica, complexa, não pontual ou fragmentada.

Além das Faculdades, a Instituição era mantenedora do Colégio FAAT-Jr (ensino fundamental e médio) para o qual eu fiz Rodas de histórias por algum tempo com as crianças da primeira à quarta série. Por falta de apoio do colégio, as Rodas deixaram de acontecer, ficando a certeza da importância das articulações dos processos culturais em redes, tema que abordarei adiante.

Com a volta ao trabalho, retomo as inquietações anteriores - "O que leva aqueles alunos à Biblioteca?” “O que a Biblioteca levava, na prática, a eles?” Não me sentia em condições de responder. Todavia, percebia que não era necessariamente o conhecer de cada um que mediava as buscas, mas uma necessidade centrada nas solicitações dos professores, um dever institucional de conhecer. Novas dúvidas se colocaram. "Haveria pontes entre o dever de conhecer, imposto aos alunos, e o desejo de conhecer? A curiosidade se manteria viva a despeito das metodologias de formação universitárias utilizadas, centradas na transmissão e na vontade quase exclusiva do professor?" Comecei a pensar numa pós-graduação, pois essas inquietações cresciam e pediam para ser respondidas.

Voltei à Universidade como ouvinte na disciplina: Formação de público para ação cultural. Naquele momento as idéias ainda estavam cruas; eu pensava em algo como: alfabetização cultural. Por outro lado, a instituição onde trabalhava criou um departamento de eventos culturais, separado da biblioteca. $\mathrm{O}$ trabalho que vinha tendo um encaminhamento orgânico e sistemático passou a ser fragmentado e eventual. $\mathrm{O}$ Diretor me chamou e pediu que conversasse com a diretora de um abrigo para menores onde havia um pequeno acervo. A diretora gostaria que eu desse "uma olhada".

Como acontece muitas vezes com acervos a serem "olhados", encontrei muita riqueza e muito material a ser descartado. Todavia, ao olhar através da janela da sala onde se encontrava o acervo, meninos brincando de bola ali fora me chamaram a atenção: "Quem são eles? Como vivem aqui? O que fazem? Que informações receberiam? Como elas lhes chegavam? Seriam eles castigados quando fizessem uma 
lição mal feita? Para que esse acervo tão distante deles? Por que duas portas a serem destrancadas para chegar até ele, se o acervo é deles!? Então, por que está trancado?"

Surgiu o desejo de fazer um projeto com aquelas crianças. Organizar os livros não bastava. "Quem eram aqueles meninos? O que esperavam daquilo? O que eu posso oferecer?" Retomei minhas anotações de PROESI. Escrevi um projeto preliminar de oficinas de papel, tentativas de roda de história, tentativas de oficinas de percepção e outras tentativas. Digo tentativas, porque essas ações nesses ambientes e com esse público são complexas desde a concepção até a implementação. Fatores de natureza variada e, frequentemente, conflitos se colocam em cena nos momentos das oficinas e minha visão se limitava às cenas sem entender seus porquês.

Em 2005, o CRB - Conselho Regional de Biblioteconomia - $8^{\mathrm{a}}$ Região abria inscrições para o $5^{\circ}$ prêmio Laura Russo essas eram feitas por meio do portal do Viva Leitura $^{6}$. O projeto tinha que estar vinculado a alguma instituição. Então o submeti à direção da FAAT. Com a aprovação do projeto - Abrace uma biblioteca e incentive programas de leitura - encaminhei-o ao concurso e ele recebeu o segundo lugar. Foi interessante observar toda a propaganda feita pela Instituição. De certa forma, me sentia envergonhada, porque tudo estava no início e ninguém sabia onde tudo isso ia dar. Foi quando a ONG "Consciência Solidária" se aproximou do projeto, com o intuito de auxiliar com recursos materiais, sendo que os adolescentes que participavam desta ONG contribuiriam com o seu tempo. A princípio tudo ótimo, uma apresentação de música brasileira garantiu uma boa arrecadação de livros e, melhor, na sua maioria infantil e juvenil.

Começamos a capacitação, primeiramente para alunos do curso de Letras e Pedagogia, como voluntários. No entanto suas horas no projeto contariam como atividades complementares para o curso. Esses alunos deveriam passar tais conhecimentos aos adolescentes e estes aos jovens do Abrigo. Logo na primeira passagem, a ação se mostrou ineficiente, uma vez que o grupo de adolescentes da ONG não poderia trabalhar mais que seis horas por semana, enquanto só de capacitação eram quatro horas por semana. A fórmula mostrou-se inviável. A capacitação era em Serviço de Informação e Programas de Leitura, com momentos de prática, quando nos reuníamos no Abrigo Nosso Lar, para desenvolver algumas atividades junto às crianças.

\footnotetext{
${ }^{6}<$ http://www.vivaleitura.com.br/calendarioxyz.asp $>$
} 
Nesse período estava matriculada na disciplina Biblioteca, Recepção, Aprendizagem, como aluna especial. O trabalho com as crianças me motivava e desafiava, levando-me à busca de compreensão de minha prática profissional. A disciplina mostrava a Leitura em seu sentido restrito, tratando-a como uma relação silenciosa do leitor com o texto escrito. A Leitura só ocorreria quando ocorresse transformação em quem leu. A leitura naquela disciplina aparecia, portanto, estritamente ligada ao texto escrito, a alfabetização estritamente ligada ao alfabeto, sendo redundante e impróprio, por exemplo, dizer alfabeto visual. Assim, me despedi da idéia de pesquisar sobre alfabetização cultural.

Participando do lançamento do PNLL (Programa Nacional de Livro e Leitura), ouvi da Profa. Dra. Ana Maria Marques Cintra uma frase que me marcou profundamente e remeteu novamente à idéia de abordar a criança a partir de sua personalidade e não como uma massa: "a Leitura tem que passar pela epiderme". Aquilo ressoou em meus ouvidos como um sino, uma poesia, confirmando intuições.

Entre curso de capacitação, mudança da Instituição para um local maior (ao lado do Abrigo Nosso Lar) e recepção a nada menos que sete comissões do MEC para avaliações dos cursos na Faculdade transcorreu um ano e a execução do projeto foi interrompida. Os alunos, agora capacitados, tinham outras prioridades e não precisavam mais das horas complementares e, há muito, a relação com a ONG ficara esquecida ao sabor do "primeiro isso para depois aquilo". Fui chamada, então, pela diretoria do abrigo que queria saber se "eu iria realmente fazer alguma coisa ou se eu só estava querendo enfeitar meu currículo".

Naquela mesma semana, um dos diretores da Faculdade dizia para eu começar a cuidar dos meus interesses: pensar numa pós e no meu trabalho no Abrigo. Colhi essa sugestão literalmente. Haveria um seminário de bibliotecas universitárias (SNBU), enviei um artigo que foi aprovado. Pensando no sentido da leitura e nos modos como sua mediação pode ser determinante e fundamental para crianças e adolescentes em situação de risco, fiz minha inscrição para a pós-graduação na ECA e na PUC. E, naquele semestre, enquanto me preparava para as provas, dediquei-me ao Abrigo. Apresentaram-se novos voluntários, éramos um grupo de nove e o tempo dizia que tanto a capacitação como as praticas deveriam acontecer concomitantemente.

Naquele semestre o projeto no Abrigo foi realizado de forma metódica, articulada, por meio de concepções e de práticas. Uma vez por mês assistíamos a filmes sempre enfocando o lado fantástico e imaginário dos contos, das rodas de história, numa 
tentativa de resgatar narrativas, suas possibilidades e reinvenções, como por exemplo, Chapeuzinho vermelho / Chapeuzinho Amarelo/ Os três Porquinhos/ A Verdadeira História dos Três Porquinhos... Como resultado, observou-se um maior interesse das crianças pelo espaço da biblioteca. Ainda que distantes, alguns queriam ajudar na organização. Criamos na internet o grupo Trilhas e Leituras, para facilitar a troca de informações sobre as atividades. Desse grupo surgiu o blog homônimo, com a finalidade de ter crianças do Abrigo como moderadoras, o que se apresentou inviável, tanto por questões técnicas (indisponibilidade de equipamentos), como administrativas (rejeição dessa necessidade pelos gestores).

Estes fatores, assim como minha mudança para uma cidade vizinha, levaram-me a decidir por um outro abrigo, um local onde pudesse contar com um apoio maior dos gestores e pudesse tanto alimentar as suas idéias como as minhas próprias, em benefício da melhoria do atendimento às crianças e jovens.

Nesse momento ingressei na pós-graduação com o objetivo de entender como se dava a apropriação das informações pelas crianças e pelos adolescentes nestas situações de risco e abrigados. Mais: qual o papel do mediador cultural nessa situação? Outras questões foram também se definindo no percurso: o vínculo entre os mediadores e as crianças e jovens, entre os parceiros de leitura, deve ou não ser estabelecido? Que vínculo é esse? Em que medida?

No meu entender, foram várias as questões que me trouxeram à pós e conduziram a este trabalho. Todas vão desembocar na mediação cultural como categoria articuladora que, transformada em objeto de pesquisa, constitui um território, um porto onde minhas inquietações vindas de longe e alimentadas pelas viagens objetivas e simbólicas finalmente se ancoravam.

É a partir desse ponto de ancoragem, dessa terceira margem entre o texto e o leitor que o olhar se estende para os oceanos sígnicos, a fim de com eles dialogar e abrir espaços para novas navegações. As inquietações são tantas, mas precisam confluir para um ponto capaz de articular a profusão de idéias, conceitos e práticas, um objeto com estatuto epistemológico definido. Esse é o lugar do conceito de mediação cultural dialógica como objeto teórico desta pesquisa e, ao mesmo tempo, na minha vivência em projetos de protagonismo cultural, conceito e ações que podem ser perseguidos pelos mediadores em suas práticas em favor do conhecimento, da cultura e das viagens reais, imaginárias e simbólicas a que toda leitura criativa possibilita e convida. 


\section{Justificativa: Por que Mediação Cultural Dialógica}

$\mathrm{O}$ "Plano nacional de promoção e defesa do direito da criança e adolescente à convivência familiar e comunitária" " salienta que proporcionar aos seres que estão crescendo os pontos referenciais, os elos de identidade e as bases para a atribuição de significados às informações, deve ser objetivo não só da escola, mas de todos responsáveis pelo universo educacional, cultural e científico. Segundo tal documento:

Os espaços públicos freqüentados por crianças e adolescentes e as instâncias de formulação de políticas públicas constituem importantes instrumentos para os exercícios dos direitos de cidadania, sob a perspectiva tanto de incentivar a criatividade no campo das ciências, das artes e dos esportes, quanto na formação de lideranças infantojuvenis. (BRASIL, 2006, p. 71).

Dentre os muitos fatores que possibilitam a formação de crianças e jovens, enquanto cidadãos, está o direito de acesso à cultura e às suas diversas manifestações. Conforme se observa no ECA - Estatuto da Criança e do Adolescente ${ }^{8}$ :

Art. 54 É dever do Estado assegurar à criança e ao adolescente:

$\mathrm{V}$ - acesso aos níveis mais elevados de ensino, da pesquisa e da criação artística, segundo a capacidade de cada um;

Art. 94 As entidades que desenvolvem programas de internação têm as seguintes obrigações, entre outras:

$\mathrm{XI}$ - propiciar atividades culturais, esportivas e de lazer.

Da mesma forma que do ECA, destacamos da Lei de Diretrizes e Bases da Educação Nacional (BRASIL, 1990) os seguintes artigos:

Art. 3

$\mathrm{X}$ - valorização da experiência extra-escolar;

XI - vinculação entre a educação escolar, o trabalho e as práticas sociais.

Art.12. Os estabelecimentos de ensino, respeitadas as normas comuns e as do seu sistema de ensino terão a incumbência de:

VI - articular-se com as famílias e a comunidade, criando processos de integração da sociedade com a escola;

\footnotetext{
7 BRASIL. Plano nacional de promoção, proteção e defesa do direito da criança e adolescente à convivência familiar e comunitária. Brasília: Conselho Nacional de Assistência Social, 2006.

${ }^{8}$ Disponível em: <http://www.planalto.gov.br/ccivil_03/Leis/L8069.htm>
} 
Art. 13

VI - colaborar com as atividades de articulação da escola com as famílias e a comunidade.

Art.14

II - participação das comunidades escolar e local em conselhos escolares ou equivalentes.

Em relação ao ensino fundamental, vale mencionar:

Art.32.

I - o desenvolvimento da capacidade de aprender, tendo como meios básicos o pleno domínio da leitura, da escrita e do cálculo.

Enfocando tais textos governamentais que determinam direitos a serem consolidados pelas instituições diretamente vinculadas à infância e à adolescência, mas que, por outro lado, devem ser também defendidos pela sociedade como um todo, observa-se a necessidade de criação de dispositivos educacionais e culturais que atendam tanto às questões pragmáticas, quanto às questões de ordem teórica, viabilizando e estabelecendo a argamassa da construção de conhecimentos necessários ao saber viver.

As competências e as habilidades para entender, aceitar ou não certos valores, certas manifestações ditas e proclamadas pela sociedade como culturais, por exemplo, as artes, não são inatas. Mesmo a imaginação necessita de cultivo para que floresça em toda a sua exuberância e possibilidades.

Observa-se, por meio das vivências e de textos tratando de questões referentes aos abrigos que a assistência dada a crianças e adolescentes em tais locais, no geral, dá-se por satisfeita quando consegue atender necessidades básicas (alimentação, um local pra dormir e tomar banho). Algumas vezes, encontram-se referências a quesitos envolvendo entretenimento ou pouco mais que isso. Em tais situações, estamos diante de um quadro de panis et circensis sem dúvida nenhuma necessário à vida, mas e a educação? E a cultura? Como tais processos são vivenciados nesses contextos?

A educação é condição da existência humana, uma condição determinada pelo nascimento e regada de responsabilidades que implicam decisões de amor concretizado em gestos e atos. Como nos lembra Hannah Arendt, será que:

[...] amamos as nossas crianças o bastante para não expulsá-las de nosso mundo e abandoná-las a seus próprios recursos e tampouco arrancar de suas mãos a oportunidade de empreender alguma coisa nova e imprevista para nós, preparando-as em vez disso com 
antecedência para a tarefa de renovar um mundo comum. (ARENDT, 2007, p. 247).

Se a cultura, por sua vez, em suas diferentes manifestações, sob a égide do mercado e da sociedade midiática, tende com freqüência a se esvaziar na sociedade em geral, nos abrigos apresenta condições mais precárias, transformando-se com frequência em entretenimento, muitas vezes reduzido a mero espetáculo audiovisual.

Assim, crianças e adolescentes em situação de risco vivem risco duplicado nas instituições que as acolhem enfrentando limitações de todas as ordens a suas disposições, interesses e possibilidades culturais, uma série de limitações com implicações diretas na formação de competências e atitudes nos processos de apropriação cultural. Diante disso, faz-se necessário lançar mão de ações que viabilizem tanto o acesso, quanto a apropriação de conteúdos da cultura, tendo em vista a participação afirmativa e ampla no mundo em que vivem.

Necessárias, as ações voltadas em especial para esse grande contingente de crianças que se acham, no país, em situação de abrigo precisam ainda contar com princípios que contrariem o discurso monológico que preside a maioria das intervenções voltadas para esses públicos. Crianças e adolescentes em situação de abrigo requerem, tal como todas as demais da mesma faixa etária, mediações socioculturais específicas, compatíveis com suas condições e interesses. Por outro lado, requerem também mediações diferenciadas, que levem em conta suas condições particulares, situação distinta do que pode comumente ser observado no dia-a-dia da maioria das instituições que as acolhe.

O Abrigo oferece-nos, pois, uma oportunidade ímpar para pensar, refletir e caminhar tanto em direção à dialogia cultural, quanto ao protagonismo cultural, já que suas condições concretas, observadas historicamente entre nós, são desafios tanto à objetivação de um termo como do outro, da mesma forma que um desafio aos modos como eles são considerados em contextos de outras naturezas.

Nesse sentido, é pertinente perguntar: os conceitos de dialogia e de protagonismo cultural revelam-se nos abrigos da mesma forma que em outros espaços institucionais destinados a crianças e jovens?

A resposta poderá contribuir para que novas concepções e novas práticas sejam incorporadas a esses espaços especiais de educação e de cultura. 


\section{Organização do trabalho}

O presente trabalho está organizado em três partes, além desta introdução: Parte A - apresenta o quadro referencial, tendo em vista a trama de conceitos envolvidos na mediação cultural dialógica; Parte B - discute questões metodológicas e Parte C apresenta a pesquisa e seus resultados no contexto específico do abrigo onde foi realizada, caracterizando-o, discutindo os processos de institucionalização de crianças e adolescentes e, por fim, ainda nesta parte apresentamos as considerações finais. 
Parte A

Conceitos 


\section{O conceito de mediação cultural dialógica}

Ao abordamos o conceito de mediação, buscamos autores que a compreenderam na perspectiva dialógica, colocando em correspondência os objetivos deste trabalho e seu corpo teórico e metodológico.

O termo mediação aparece definido no dicionário Aurélio do seguinte modo:

Mediação. [Do lat. mediatione] S. f. 1. Ato ou efeito de mediar. 2. Intervenção, intercessão, intermédio. [...] 3. Jur. Intervenção com que se busca produzir um acordo. 4. Jur. Processo pacífico de acerto de conflitos internacionais, no qual (ao contrário do que se dá na arbitragem) a solução é sugerida e não imposta às partes interessadas. 5. Agenciamento, corretagem. 6. Mat. Operação de somar termo a termo duas frações ordinárias. 7. Rel. Segundo a doutrina da Igreja Católica, função de Maria e dos Santos junto a Cristo e a Deus. (AURÉLIO, 1975, p. 903).

Desse modo temos, segundo tal visão do dicionário, que:

a) a mediação é uma ação presente em áreas distintas;

b) a mediação é portadora de intenções que envolvem partes;

c) a intensidade e a maneira como tal mediação acontece variam em função das partes que estão envolvidas em tal ato.

Para Williams, a palavra mediação (mediation - termo em inglês, por ele usado) "[...] tornou-se ainda mais complexa por seu uso como termo-chave em diversos sistemas do pensamento moderno. [...]" (WILLIAMS, 2007, p. 272). Procedente do latim mediare - dividir ao meio, ocupar uma posição média, agir como intermediário ${ }^{9}$, a mediação está relacionada a diversos contextos, sejam eles teóricos ou práticos. Desse modo, o termo pode ser entendido de diferentes maneiras, dependendo do contexto onde apareça.

Segundo José Ferrater Mora, os filósofos costumavam aplicar o termo mediação para referir-se ao ato de relacionar dois elementos distintos. Nessa perspectiva, “[...] a

\footnotetext{
${ }^{9}$ WIILLIAMS, Raymond. Palavras-chave: um vocabulário de cultura e sociedade. São Paulo: Boitempo, 2007. p. 273.
} 
mediação foi entendida como a atividade própria de um agente mediador que era ao mesmo tempo uma realidade “intermediária' [...].” (MORA, 1978, p. 1919, grifo meu).

Semelhante formulação encontramos no dicionário Lalande, citado por Perrotti: ali, a mediação aparece como a " [...] 'ação de servir de intermediário entre dois termos ou dois seres (considerados como dados independentemente desta ação)' [...]" e ainda, a “[...] 'mediação é a própria coisa que exerce ou que constitui uma mediação' [...]" (PERROTTI, 2008, p. 84).

O termo mediação apresenta, historicamente, um desenvolvimento que, segundo Williams apresentaria três etapas:

[...] (a) encontrar um ponto central entre dois opostos, como em muitos usos políticos; (b) descrever a interação de conceitos ou forças opostas na totalidade a que supostamente pertençam ou de fato pertencem; (c) descrever essa interação como substancial, com formas próprias, de modo que não seja um processo neutro de interação de formas separadas, mas um processo ativo no qual a forma de mediação altera as coisas mediadas, ou indica a natureza delas por sua própria natureza. (WILLIAMS, 2007, p. 274).

Certamente, a terceira etapa se aproxima mais daquilo que aqui buscamos: uma mediação que não seja compreendida como neutra, mas como processo ativo definido e relacionado com contextos, atores e processos específicos.

Nesse sentido, os contextos onde esta pesquisa se desenvolveu, o abrigo, o carro, a biblioteca, bem como seus atores, isto é, os mediadores (nesse caso também o próprio pesquisador), as crianças, os adolescentes, os monitores e outros agentes sociais constituem uma dinâmica particular dos processos de interlocução cultural, atuando, portanto, nos processos de ressignificação ali envolvidos. Daí Williams ressaltar que a compreensão atual do termo mediação não autoriza que este seja tomado como uma ação neutra ou mesmo indireta ou espúria, sentido que por vezes o termo assume em concepções filosoficamente idealistas: ${ }^{10}$

\footnotetext{
10 “[...] na tradição marxista [...] a mediação assumia, às vezes, o sentido de conexão indireta, [...] um sentido desfavorável, em contraste entre relações reais e mediadas, sendo, portanto, um dos processos essenciais não da consciência, mas da IDELOGIA. Esse uso de mediação harmonizou-se com o uso moderno de MÍDIA ou COMUNICAÇÃO DE MASSA, em que considera que certas agências sociais estão deliberadamente interpostas entre a realidade e a consciência social para impedir a compreensão da realidade. [...]" (WILLIAMS, 2007, p. 274, grifos e itálicos do autor).
} 
[...] uma atividade direta e necessária entre diferentes espécies de atividade e de consciência. Tem formas próprias, sempre específicas. [...] Todas as 'coisas', e nesse contexto notadamente as obras de arte, são mediadas por relações sociais específicas, mas não podem reduzirse a uma abstração dessas relações; a mediação é positiva e, em certo sentido, autônoma. [...] (WILLIAMS, 2007, p. 275, grifos do autor).

Positiva e, em certo sentido, autônoma, como afirma Williams, a mediação se dá em uma realidade concreta e definida, com formas próprias e específicas. Assim sendo, faz-se necessário considerar formas e especificidades que a mediação toma nos abrigos, bem como formas e especificidades que poderão apresentar, tendo em vista demandas e expectativas de crianças e adolescentes em situação de abrigo.

A mediação se faz presente nos mais diferenciados meandros da vida em comunidade, seja em sua linguagem, suas ações e concepções. Segundo Rodrigues, mediação é um processo de "[...] interlocução ou interacção entre os membros de uma comunidade, pelo qual se estabelecem, alimentam ou restabelecem laços de sociabilidade, constituindo assim o mundo da vida. A linguagem e a acção comum são os fatores privilegiados de mediação." (RODRIGUES, 2000, p. 84).

Definição semelhante apresenta Vigotski, ao afirmar que: “[...] a transmissão racional e intencional de experiência e pensamento a outros requer um sistema mediador, cujo protótipo é a fala humana, oriunda da necessidade durante o trabalho." (VIGOTSKI, 2008, p. 7) Temos assim, na linguagem, nas ações em geral e nas concepções elementos constitutivos dos processos de mediação social.

De acordo com a Enciclopédia Einaudi, o conceito de mediação implica diversos aspectos que envolvem desde o homem em estado de natureza até o ser histórico em toda sua complexidade: “[...] o homem como indivíduo só adquire um significado real após um desenvolvimento milenário de mediações e o seu pressuposto real é o de ser sempre membro de uma comunidade. [...]" (EINAUDI, 1988, p. 145, grifo do autor). Permeado pela linguagem, somos, pois, essencialmente, seres em relação, movimento a partir do qual construímos e somos construídos pelos significados e objetos históricos e culturais.

Sendo a mediação um ato de aproximação de pontos que estão distantes, ela é, então, intermediação. Como tal, não se configura em gestos mecânicos ou neutros, quando se trata de mediação cultural. Seja por meio da ação direta de um mediador, seja pela ação indireta dos objetos, das mídias, das configurações de espaços reais e 
virtuais, os processos de mediação implicam sempre discursos, isto é, significações, interpretações, codificações do mundo e dos seres que o habitam. Tais atos estão, portanto, entremeados de sentidos e de valores, não sendo, portanto, os processos de mediação simples instrumentos ou ferramentas tendo em vista a realização de uma finalidade ou um objetivo. Ou seja, o caráter diferencial da mediação aqui apresentada é que ela é constitutiva, intrínseca a todo o processo de significação, de apropriação simbólica dos conteúdos culturais. Ela é, portanto essencial e não instrumental.

Nesse sentido o conceito de mediação cultural se constitui e constitui como “[...] um conjunto de elementos de diferentes ordens (material, relacional, semiológica) que se interpõem e atuam nos processos de significação.” (PERROTTI, 2007, p. 84). Portanto, tal conceito se relaciona a outros, tais como o de dispositivo e o de protagonismo cultural, a serem adiante definidos.

Diante da variedade e da diversidade de termos e áreas que tratam do conceito de mediação, faz-se necessário ressaltar quais são os aspectos essenciais que a realização das oficinas de leitura com crianças em situação de abrigo permitiu apreender e que deverão ser incorporados por nós à sua definição.

\subsection{Aspectos da mediação}

Das definições apresentadas acima, podemos extrair alguns elementos relevantes a serem considerados como aspectos da mediação aqui requerida. Podemos entender a mediação como ação que envolve partes distintas e independentes. Desse modo, apresenta-se como terceiro termo autônomo entre partes nos processos de interlocução e/ou de interação, como algo que acontece no "entre", seja entre os membros de uma comunidade, seja entre um indivíduo e uma interface numa rede digital. Nessas interações, as partes se constituem, mas também a própria mediação é alimentada, atualizada nos e por meio dos discursos e objetos, nas e por meio das ações e concepções aí envolvidas. Nota-se que a mediação se objetiva por meio de comunicação, envolvendo linguagens que estabelecem e restabelecem laços de sociabilidade. Estar vivo é, portanto, estar mediando e sendo mediado. A mediação, portanto, é implícita à necessidade de comunicar e de se fazer conhecido, configurandose enquanto ação que envolve um conjunto de elementos orgânicos e inorgânicos. 
[...] Na concepção de Vygotsky, a relação do homem com o mundo físico e social é sempre mediada, isto é, se dá por meio do concurso de um elemento intermediário, que a torna mais complexa. Esses elementos mediadores são de naturezas distintas e referem-se ao uso de instrumentos e de signos. (MIRANDA, 2005, p. 18).

Diante do exposto, podemos afirmar que as realizações culturais - assim como nossas relações com a natureza - nos chegam sempre mediadas por uma série de elementos de diferentes espécies e, diferentemente do que colocam modelos apoiados em concepções binárias de tais relações, nossas relações com o mundo natural e cultural são de natureza ternária, implicando sempre sujeitos, mundo e dispositivos de mediação (linguagens, técnicas, processos, materiais, relações com outros sujeitos).

A mediação, nesta dimensão, é um dos elementos dos processos de produção de significados e não apenas um elo, um canal que viabilizaria tal trânsito. Enquanto tal, a mediação, seus modos concretos de efetivação produzem implicações diretas e indiretas sobre a produção, sobre a recepção e sobre si mesma. A figura abaixo ilustra essa outra forma de conceber a mediação e os processos de significação:

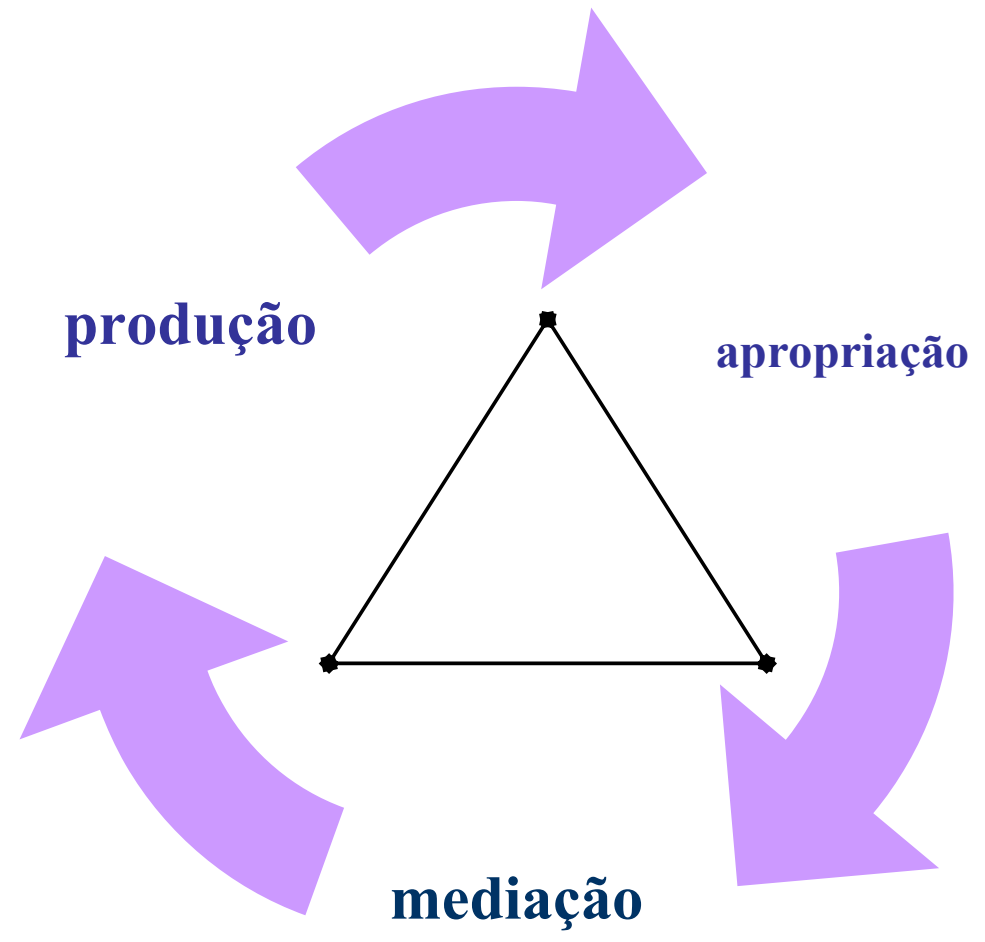


Uma das alterações mais importantes implicadas nos modelos triangulares, em relação aos modelos binários de produção da significação está na compreensão dinâmica e ativa dos elementos aí presentes, tornando-se a recepção um ato de apropriação e não simplesmente de assimilação de significados. E é, em relação a tal dimensão que o ato de mediação se define. Assim como ele próprio, nem produção, nem recepção são entendidas como categorias passivas nos processos comunicacionais e culturais.

Os atos de mediação não se dão no vazio. Implicam linguagens, objetos e sujeitos em relações dinâmicas. Constituem-se e constituem atividades discursivas. Eles dialogam, narram, negociam simbolicamente estratégias e criam performances. Eles articulam e são eles mesmos dispositivos.

\subsection{Mediação e dispositivos}

Se a mediação não acontece ao acaso ou no vazio, pressupõe sujeitos em relação com outros sujeitos, com objetos, com linguagens, com processos e suportes de diferentes naturezas, físicos, concretos, objetivos, mas também, relacionais, abstratos, subjetivos. O ato cultural de produção, circulação e apropriação das significações envolve, portanto, uma série de empreendimentos diversificados, sem os quais as significações não se processam em nenhuma das suas dimensões. $\mathrm{O}$ termo dispositivo ${ }^{11}$ nomeia esse conjunto diversificado de elementos constitutivos da cultura, essa categoria essencial dos atos culturais, seja na dimensão objetual, seja na discursiva. Os dispositivos, nesse aspecto, funcionam, mas, mais do que simplesmente isso, significam e participam dos processos de significações.

Um dispositivo é uma instância, um local social de interação e de cooperação que possui suas intenções, seu funcionamento material e simbólico, enfim, seus modos de interações próprios. A economia de um dispositivo - seus funcionamentos - determinado pelas intenções,

\footnotetext{
${ }^{11}$ Le dispositif s'entend, omme le rappelle le dictionnaire, dans une acception prioritairement technique, comme « un ensemble de pièces constituant un mécanisme, un appareil quelconque ». Puisd'englober, par extension, tout agencement d'éléments humains ou matériels, réalisé en fonction d'un but àatteindre. (LE DISPOSITIF, 2008).
} 
se apóia sobre a organização estruturada dos meios materiais, tecnológicos, simbólicos e relacionais que modelam, a partir de suas características próprias, os comportamentos e as condutas sociais (afetivas e relacionais), cognitivas dos sujeitos. (PERAYA, s.d.).

A partir de uma série de reflexões sobre o conceito de dispositivo, Pieruccini diz que dispositivo é "[...] uma instância, um local social de interação e de cooperação com suas intenções, seu funcionamento material e simbólico. [...]” (PIERUCCINI, 2004, p.33) Temos aqui um tecido de agenciamento por onde passam relações de forças. Entre funcionamento material e simbólico, há uma correlação, e, nessa cooperação, nessa interação tem-se a causa imanente ${ }^{12}$, uma causa atualizada pelo seu efeito, ou seja, o ambiente, os dispositivos, seus sujeitos sofrem alterações, variações, na medida em que vão ocorrendo as interações “[...] Por isso, nela há correlação, pressuposição recíproca entre a causa e o efeito, entre a máquina abstrata e os agenciamentos concretos (é a esses que Foucault reserva mais frequentemente o nome de dispositivos). [...]" (DELEUZE, 2006, p. 46).

Em uma biblioteca, em um museu, em uma mala de livros, em uma oficina de leitura, em um abrigo, enfim, seja em que espaço for, temos a conexão entre vários dispositivos e, cada qual, tem a sua especificidade, seu modo de estruturação do espaço e do tempo, do conjunto de relações práticas, discursivas e tecnológicas. Os dispositivos constituem, portanto uma ordem, a ordem dos dispositivos. E esta pode ser monológica ou dialógica, dependendo do modo como são agenciados e postos em funcionamento os elementos que os constituem.

Nesse sentido é que abordaremos a seguir um dos elementos fundamentais de tal ordem, tendo em vista a concepção da mediação cultural dialógica.

\subsubsection{O mediador}

Figura fundamental na relação entre produção e apropriação, o mediador desempenhara um papel não meramente técnico, mas, sobretudo participativo na construção do significado. Por meio dele o conceito de dispositivo se corporifica e

\footnotetext{
12 " [...] uma causa que se atualiza em seu efeito, que se integra em seu efeito, que se diferencia em seu efeito. Ou melhor, a causa imanente é aquela cujo efeito a atualiza, integra e diferencia. [...]" (DELEUZE, 2006, p. 46).
} 
humaniza, envolvendo gestos, voz, posturas, performances olhares, movimentos. É nesse sentido que ele também vai se construindo como sujeito afirmativo e não como mero canal veiculador de sinais que lhes são externos.

O mediador exercendo esse e outros tantos papéis caminha juntamente com as evoluções históricas do conhecimento, das produções em seus mais diferenciados suportes informacionais. Martín-Barbero, ao tratar questões culturais, comunicacionais e políticas nos contextos das classes populares traz a idéia de um mediador intelectual orgânico no sentido gramsciano ${ }^{13}$ :

Nesse momento a comunicação cultural deixa de assumir a figura do intermediário entre criadores e consumidores para assumir a tarefa do mediador que atua na abolição das barreiras e das exclusões sociais e simbólicas, no deslocamento do horizonte informativo das obras para as experiências e as práticas e na desterritorialidade das múltiplas possibilidades da produção cultural. É óbvio que a nossa proposta não é a de uma política que abandone a ação de difundir ou dar acesso às obras e, sim, a de crítica a uma política que faz da sua difusão o seu modelo e a sua forma. (MARTÍN-BARBERO, 1993, p. 34).

Podemos entender assim que a compreensão do mediador como um sujeito atuante e ativo nos processos culturais, acrescenta à dimensão da difusão e da transmissão que definiam o termo no passado, a da apropriação cultural, redefinindo-o enquanto categoria que encontra sua identidade no diálogo. Nesse sentido, o ato de mediar implica a percepção de si e da figura do outro, ou no dizer do Buber, do Tu e do Isso (BUBER, 1979).

\subsubsection{Mediação e Midiatização}

Toda a história da humanidade vem se desenvolvendo a partir de uma necessidade de comunicar, de passar e receber informações. É assim desde as pinturas rupestres até os dias atuais com a convergência de tecnologias altamente sofisticadas em suportes que acoplam em si diversas funções. A evolução das mídias, dos meios, dos suportes da informação acompanha a evolução do pensamento humano, de seus questionamentos frente às solicitações da vida, das suas descobertas, e de seus relacionamentos com o outro. Assim, o homem vai inventando, transformando e criando instrumentos que o

\footnotetext{
${ }^{13} \mathrm{O}$ intelectual orgânico se contrapõe ao tradicional, na visão de Gramsci, ou seja, aquele que contribui para mudanças na sociedade, trata-se de um construtor, aquele que não é indiferente, mas que toma partido. (WITKOSK, 2000).
} 
ligam às tarefas cotidianas, ao trabalho e também aos seus desejos. Os instrumentos, as ferramentas, os objetos ligam o homem ao mundo.

Se as mídias se desenvolvem, os processos de ação e interação com esses meios se desenvolvem também. Os meios envolvem e requerem sensibilidades, modos de ver, de perceber, aprender e de apreender. Segundo McLuhan, autor da célebre formulação o meio é a mensagem

[...] cada meio comunica seu próprio funcionamento, não como o "código" ou a "lógica" de um sistema, mas como um jogo participativo, um modo de usar inseparável de sua relação física com um usuário, cujas atitudes e crenças vêm a ser informadas e enformadas por esse mesmo meio. (VALVERDE, 2003, p. 22).

Tal colocação vai ao encontro da definição aqui apresentada de dispositivos, ou seja, estes não são meramente recursos técnicos, meio de informação, ferramentas, suportes. Ao lançar mão e agenciar os variados aspectos que os constituem, tornam-se discursos, significações e referenciais que incidem sobre as interações vivenciadas em espaços e tempos.

Os dispositivos, contudo, vão se fazendo e refazendo no tempo e no espaço, com implicações diretas nos processos de produção, circulação e recepção de informações e cultura. Segundo Pieruccini,

[...] A invenção de suportes de inscrição das representações, concedendo-lhes possibilidades de circulação para além do âmbito imediato de produtores, instituiu um novo paradigma de mediação, não mais exclusivamente natural, dependente do aparato biológico dos sujeitos. O corpo, como instrumento de transferência e recepção ganhou extensão, prolongamentos que os meios técnicos de registro propiciam. [...] (PIERUCCINI, 2004, p. 39).

Tais mudanças, por outro lado, não alteram um dado essencial, inerente aos processos de mediação cultural: a mediação depende de algum meio físico, objetual, seja o mediador, seja uma interface buscada na internet. Além disso, segundo Valverde, “[...] ela é sustentada pela percepção sensorial, mas não se reduz a ela, uma vez que opera num ambiente discursivo e segundo uma disposição (um pathos) que se traduz em determinados usos e costumes." (VALVERDE, 2003, p, 21).

Os usos e costumes da sociedade contemporânea sofrem alterações profundas no que se refere às suas formas de comunicação, portanto, de relacionamento. Daí ser 
possível falar, em nossa época, de uma nova ecologia comunicacional ${ }^{14}$,baseada em interações que fazem uso crescente das mídias tecnológicas. Segundo alguns autores, já não é apropriado falarmos apenas de mediação, pois o que temos é um processo generalizado de midiatização das sociedades ${ }^{15}$, em escala planetária. Com base em tais autores, Pieruccini afirma:

Mediação e mediatização são, portanto, conceitos distintos que, apesar de tangenciais, não podem ser confundidos ou substituídos, em razão da natureza e capacidades de intervenção que operam sobre a relação sociocultural com o conhecimento e com a memória social. (PIERUCCINI, 2004, p. 40).

Evidentemente, os termos mediação e midiatização não são excludentes e se constituem como indispensável um ao outro. Todavia, é preciso considerar que, na atualidade, as mediações culturais apresentam uma complexidade que não possuíam no passado, quando os dispositivos aí implicados não apresentavam as características que revelam na atualidade.

\subsection{Mediação e vinculação}

“[...] Mas de que serve ficar aqui a ensiná-los! Não será tão já que lhes poderão abrir os olhos, é claro, mas deixem-nos ao menos cheirar alguma coisa."

Makarenko

Ao formular sua teoria do vínculo, na psicologia social, Pichon-Rivère diz que todo vínculo será sempre de caráter social, relacionando-se com a noção de papel, de status e de comunicação. Segundo tal teoria, o homem é um ser-em-relação, ou seja, está envolvido numa estrutura dinâmica e movido por motivações em campos externo e interno a si. (PICHON-RIVÈRE, 1982, p.49). A aprendizagem se situa no jogo contínuo entre esses campos, onde o vínculo contém em si a contradição da permanência - uma identidade ou uma dinâmica própria - e, da transformação constante - por conta dos papéis que as pessoas têm em suas histórias individuais e sociais integradas em tempo e espaço.

\footnotetext{
${ }^{14}$ GOMES, Pedro Gilberto. A filosofia e a ética da comunicação no processo de midiatização da sociedade. São Leopoldo: Unisinos, 2006.

${ }^{15}$ FERREIRA, Jairo. Midiatização: dispositivos sociais e de comunicação. In: Compôs. São Leopolodo, 2007.
} 
O processo de aprendizagem deve ser compreendido como um sistema de fechamento e abertura que funciona dialeticamente. Fecha-se em um determinado momento, abrindo-se em seguida, para voltar a se fechar posteriormente. Se o pensamento ficar fechado por muito tempo em uma determinada estrutura, estereotipa-se e se torna formal. (PICHON-RIVÈRE, 1982, p.108).

No caso de crianças, não criar vínculos pode ser uma estratégia de sobrevivência, caracterizada pela despersonalização, pela “[...] tentativa da perda do ser [...], não ser ninguém para não ter compromisso no vínculo. [...]” (PICHON-RIVÈRE, 1982, p.32). Continuando sua argumentação, o autor defende que “[...] a despersonalização, quando considerada em termos de vínculo, é um recurso para o qual o eu apela para se defender, para negar a si mesmo ou ao self diante de qualquer vínculo em uma estrutura qualquer, e diante de qualquer objeto.” (PICHON-RIVÈRE, 1982, p.32).

De modo geral, o vínculo é definido como “[...] a maneira particular pela qual o indivíduo se relaciona com outro ou outros, criando uma estrutura particular a cada caso e a cada momento. [...]" (PICHON-RIVÈRE, 1982, p.24) As pessoas podem se relacionar de diversas maneiras umas com as outras e também com objetos e situações, e, mesmo com uma única pessoa, tal relacionamento acontece de diferentes modos. Portanto, não há apenas um vínculo: “[...] todas as relações com objetos e todas as relações estabelecidas com o mundo são mistas. [...]" (PICHON-RIVÈRE, 1982, p. 26).

Evidentemente, criar vínculos implica a possibilidade de tais vínculos poderem ser rompidos, ou seja, o problema do vincular está associado ao do desvincular. Tanto que, comumente, muitas pessoas preferem, para não se ferirem nem ferir ninguém, manter relacionamentos meramente funcionais, profissionais, com o outro, reservando apenas a um círculo restrito, outras dimensões que os vínculos apresentam em potencial.

Considerando, todavia, os segmentos infantis e juvenis, em geral, bem como tais segmentos em especial situação de abrigo, como, todavia, criar o gosto, estimular a curiosidade em favor do conhecimento sem aquele "movimento de emoções" proposto por Maturana ${ }^{16}$, sem a criação de vínculos?

\footnotetext{
16 “[...] Movimento de emoções: não há fenômeno social sem a presença do amor. E também não há fenômeno cognitivo sem essa emoção.” (MATURANA apud PELLANDA, 2005, p. 64).
} 
O desvincular nos abrigos, geralmente acontece de maneira abrupta, como um corte. Seguindo o raciocínio de Pichon-Rivère, talvez uma das respostas possa estar na transformação constante, enquanto crescimento emocional, psicológico e intelectual não só das crianças e adolescentes que ali ficaram, como também dos monitores. Assim como há um aquecer no processo de estabelecimento de vínculos, deverá haver também esse aquecer para a desvinculação, ou seja, as pessoas envolvidas se preparam para esse momento, como numa estação. Os que ficam dão adeus aos que partem e vice-versa...

Para Pichon-Rivère, vínculo implica sempre dependência e independência, bem como sujeitos diferenciados. Há o reconhecimento do outro, ou seja, relação dialética do indivíduo com a sociedade. O vínculo pode ser, então, relação, interlocução, diálogo contínuo, não-finalizado, que ocorre a cada instante e no qual há um "entrar vivo". Segundo Bakhtin, no

[...] diálogo, uma pessoa participa totalmente e com toda a sua vida: com olhos, lábios, mãos, alma, espírito, com todo o seu corpo e todas as suas ações. Ela investe todo o seu discurso, e esse discurso entra no tecido dialógico da vida humana, no mundo do simpósio. (MORSON, 2008, p. 78).

Obviamente o vínculo dialógico, no contexto dessa pesquisa, aporta e cria corpo nas vivências culturais e, mais propriamente, nas oficinas de leitura. Nos momentos de mediação, os vínculos são estabelecidos entre o mediador e os parceiros, sendo estes formados por crianças ou adolescentes que se identificam entre si, de alguma maneira, pelo grau de leiturização ${ }^{17}$ e, também, pelas parcerias já estabelecidas escolhidas por eles mesmos dentro do abrigo.

A variável da relação individual com a qual trabalhamos a mediação cultural dialógica tem a ver com a transposição de barreiras reais ou imaginadas. Nessa passagem, as identidades vão se confirmando ou não à medida que questões de autoridade, de regras estabelecidas e de usos dos dispositivos são vivenciadas.

Dentro do quadro colaborativo, em que se dá a presente pesquisa, a ação de cada ator e os vínculos daí resultantes são determinantes. Isso fica bem caracterizado pelas relações que as crianças estabelecem com cada pessoa, dentro e fora do abrigo, podendo ser verificada, por exemplo, na familiaridade com as pessoas que atendem na biblioteca pública.

17 Termo defendido por Foucambert em detrimento a alfabetização. A leitura é tratada como um aprendizado social, da mesma natureza que o aprendizado da comunicação oral. (FOUCAMBERT, 1994) 
Diante de rodas de histórias frustradas que participamos com crianças e adolescentes em situação de abrigo, percebemos que a ausência dos elos identitários e de exemplos eram determinantes nos rumos tomados pelas ações. Constituímos-nos como sujeitos nos relacionando, estabelecendo vínculos e desvinculando-nos e, muitas vezes, nesse processo necessitamos de figuras que nos indiquem o caminho, que disponibilizem chaves para abrir as portas, principalmente àquelas que dão acesso ao entendimento. Em Vygotsky a mediação é vista como um processo de interferência na qual a resposta do indivíduo a um estímulo é auxiliada por um elo mediador.

A mediação é uma atividade indireta, internalizada e manifesta-se através de um processo cognitivo em que o ser humano opera com signos e símbolos: signos e palavras constituem para as crianças, primeiro e acima de tudo, um meio de contato social com outras pessoas. (VYGOTSKY, 1989, p. 31).

Decorre daí a formulação do conceito de ZDP - zona de desenvolvimento proximal, isto é,

[...] a distância entre o nível de desenvolvimento real, que se costuma determinar através da solução independente de problemas, e o nível de desenvolvimento potencial, determinado através da solução de problemas sob a orientação de um adulto ou em colaboração com companheiros mais capazes [...] aquilo que é zona de desenvolvimento proximal hoje será o nível de desenvolvimento real amanhã, ou seja, aquilo que uma criança pode fazer com assistência hoje, será capaz de fazer sozinha amanhã. (VYGOTSKY, 2002, p. 112).

Essa abordagem pode ser verificada no próprio desencadear da mediação, quando em diálogos, percebemos a necessidade de instigar, de provocar curiosidades, e responder de maneira que não se encerre a questão. Trata-se, neste momento, de alimentar repertórios na tentativa de criar vínculos com as "coisas intelectuais"18 - um vínculo cultural - ao mesmo tempo em que vão se constituindo elos de diferentes naturezas entre os sujeitos sociais.

Tanto o conceito de mediação e da zona de desenvolvimento proximal de Vygotsky, como o conceito de Mestrias $^{19}$ elaborado por Foucault, corrobora com a definição de mediação cultural dialógica apresentada aqui e que implica

\footnotetext{
${ }^{18}$ MONTESQUIEU. Essai sur lê goût. Paris: Rivage Poche, 1993.

${ }^{19}$ Em "Hermenêutica do sujeito" Foucault reconhece, de acordo com os diálogos socrático-platônicos, na figura de Alcebiades, três tipos de mestria, a saber: Mestria de exemplo; Mestria de competência e Mestria do embaraço e da descoberta, sendo esta exercida necessariamente através dos diálogos. (FOUCAULT, 2006, p. 159)
} 
necessariamente a criação de vínculos como os desenvolvidos por nós nas oficinas de leitura.e que serão relatados adiante.

\section{2. $O$ conceito de cultura}

"nada é mais indeterminado que essa palavra e nada mais enganoso que sua aplicação a todas as nações e a todos os periodos."

Herder

O dicionário Aurélio define cultura como:

[...] 1. Ato, efeito ou modo de cultivar. 2. Cultivo. 3. O complexo dos padrões de comportamento, das crenças, das instituições e doutros valores espirituais e materiais transmitidos coletivamente e característicos de uma sociedade; civilização $[\ldots] \quad 4 . \quad \mathrm{O}$ desenvolvimento de um grupo social, de uma nação (...) 5. atividade e desenvolvimento intelectuais; saber [...] (AURELIO, 1975, p.409).

Tais definições remetem para diferentes sentidos do termo, oferecendo-se como um leque de possibilidades e aplicabilidades que poderão ser pertinentes a esta pesquisa. Caminhando no sentido da complexidade que as definições acima representam, Raymond Williams, ao referir-se a esse termo, chama a atenção para os seguintes aspectos da palavra: do latim colere, “[...] tinha uma gama de significados: habitar, cultivar, proteger [...]" (WILLIAMS, 2007, p. 117). Tais definições foram se desdobrando dentro de contextos históricos e, destes desdobramentos, chegou-se, por exemplo, ao termo cultus, como sinônimo de "honrar com veneração" (WIILLIAMS, 2007).

Tomada do campo semântico originariamente ligado à agricultura, ao cuidado com a terra, tal sentido é deslocado para um correlato na dimensão espiritual. Daí a “cultura animi" de Cícero ${ }^{20}$, e já nesse primeiro uso do termo a idéia do cuidado com algo, seja a terra, seja a mente. Desta última concepção, evolui-se para o conceito de civilização, de se tornar civilizado como sinônimo de cultivar a mente, produzindo um

\footnotetext{
${ }^{20}$ Autores que citam esse início do uso histórico do termo cultura relacionado a idéia do cuidado: ARENDT, Hannah; WILLIAMS, Raymond.
} 
estado superior, em contraposição à barbárie e ao bárbaro, aquele que seria desprovido de cultura.

Diante dessa complexidade, Raymond Williams aproxima os sentidos antropológico e sociológico definindo cultura como:

[...] 'modo de vida global' distinto, dentro do qual percebe-se, hoje, um 'sistema de significações' bem definido não só como essencial, mas como essencialmente envolvido em todas as formas de atividade social, e o sentido mais especializado, ainda que também mais comum, de cultura como 'atividades artísticas e intelectuais', embora estas, devido à ênfase em um sistema de significações geral, sejam agora definidas de maneira muito mais ampla, de modo a incluir não apenas as artes e as formas de produção intelectual tradicionais, mas também todas as 'práticas significativas' - desde a linguagem, passando pelas artes e filosofia, até o jornalismo, moda e publicidade - que agora constituem esse campo complexo e necessariamente extenso. (WILLIAMS, 2000, p. 13).

É nesse sentido amplo e geral que pretendemos tomar o termo cultura, ou seja, no sentido de sistema de significação, tomando o cuidado de não polarizar o conceito de cultura, legitimando uma expressão cultural em detrimento de outra, como por exemplo, cultura erudita x cultura popular. Daí então entendermos Cultura como um sistema de significações que se realiza por meio de linguagens, objetos, processos, procedimentos, modos de sentir, pensar e agir existentes sob múltiplas e variadas formas. Esse sistema de significações se constitui no jogo complexo das interações sociais, cabe ressaltar que:

[...] Se vemos a cultura como um complexo de signos e significações (incluindo a linguagem) que origina códigos de transmissão de valores e significados sociais, podemos ao menos iniciar a tarefa de desvelar suas complexidades nas condições atuais mediante o reconhecimento de que o dinheiro e as mercadorias são eles mesmos os portadores de códigos culturais. Como o dinheiro e as mercadorias dependem inteiramente da circulação do capital, segue-se que as formas culturais têm firmes raízes no processo de circulação do capital. [...] (HARVEY, 1992, p. 269).

É nesse complexo de signos e significações - Cultura - que temos o terreno da produção, da circulação da recepção da informação. No entanto, esse círculo é dinâmico e não é fechado. Não se encerra, portanto, na recepção ou em qualquer outra das esferas que o constitui. Tal compreensão é fundamental, principalmente quando desejamos 
compreender os processos de apropriação simbólica dos bens culturais e, a partir desta, o protagonismo cultural - termo tratado adiante.

A cultura contemporânea apresenta uma característica fundamental. Junto aos recursos tradicionais, serve-se crescentemente de formas de comunicação mediadas por tecnologias. Com isso, a dimensão espaço-temporal da informação, do conhecimento e da cultura vem se alterando consideravelmente. Tais alterações têm implicações diretamente relacionadas à apropriação dos bens culturais, pois, não sendo passiva em sua natureza, esta se concretiza mediante negociações simbólicas nem sempre fáceis de serem efetivadas, ou seja, impondo jogos, disputas, enfrentamentos, conflitos, diálogos, entre repertórios individuais e coletivos que demandam saberes específicos dos sujeitos aí implicados.

Esses repertórios constituem o capital cultural incorporado, um dos três tipos de capital cultural descritos por Bourdieu ${ }^{21}$. Por ser incorporado, esse capital está diretamente ligado ao corpo, ou seja, pressupõe um investimento de tempo (não se dá instantaneamente) pessoal do sujeito. O outro não pode adquirir esse capital por mim. Por outro lado, tal capital se constitui também diretamente ligado ao social, onde intervém, por exemplo, o contexto familiar de cada sujeito, além de outras instâncias que estruturam a vida social: escola, igreja, associações de variadas naturezas, dentre outras. Portanto, é a partir das referências culturais que o sujeito vai se constituindo e se definindo como ser cultural. Segundo Bourdieu, será a soma desses capitais que determinarão o nível de apropriação simbólica dos bens culturais. (BOURDIEU, 1998, p. 74-76).

Se, "[...] conhecer é um ato de interpretação individual, uma apropriação do objeto informação pelas estruturas mentais de cada sujeito [...]" (BARRETO, 2002, p. 9), em suas relações com o ambiente, é pertinente considerarmos a existência de uma visão, de uma experiência particular do mundo, mesmo se esta se apresente sempre imersa no tempo e no espaço da vida coletiva. Sujeito e meio sociocultural estão, assim, em permanente dinâmica, em estado constante de construção e reconstrução pessoal e social, mas tal dinâmica não impede o florescimento de visões singulares do mundo por cada sujeito cultural tomado individualmente.

\footnotetext{
${ }^{21}$ Capital cultural objetivado, aquisição de bens culturais (livros, obras de artes...) através de capital econômico; b) Capital cultural institucionalizado (diplomas, certificados, títulos escolares). (BOURDIEU, p. 77-79, 1998).
} 
Temos, assim, nos processos de apropriação cultural, experiências diferenciadas de indivíduo para indivíduo, mesmo se considerarmos que a significação não existe no abstrato, que, embora ela esteja 'na mente', nutre-se obrigatoriamente da cultura, envolvendo sujeitos e signos em relações dinâmicas, concretas e contextualizadas. Desse modo, é "[...] esta localização cultural dos significados que garante sua negociabilidade e, no final das contas sua comunicabilidade.” (BRUNNER, 2001, p. 16), a apropriação cultural implica obrigatória e necessariamente sujeitos e suas experiências singulares nos processos de sua constituição.

Portanto, a cultura fornece as ferramentas necessárias para o entendimento do mundo, mas os diferentes sujeitos culturais explicam as diferenças nas formas de sua apropriação, de recriação dos significados, de construção de conhecimento e, consequentemente, do protagonismo diante dos eventos, situações, rotinas e fenômenos que a vida em sociedade e em comunidade nos apresenta.

\subsection{A leitura}

" toda a Arte, toda a Literatura, é um caminho de superação do que a vida tem de rotineiro e indiferente" SUASSUNA

Nos processos dialógicos entre texto e leitor, a leitura oferece caminhos à ponderação dos desafios que por nós enfrentados. O leitor se constitui como sujeito e também como lugar dos acontecimentos. A leitura é vivência e, nesse vivido por meio e com os signos, a escrita o assalta, permeando caminhos, construindo e desconstruindo sentidos, mostrando, indicando, desviando, obstruindo, produzindo percursos intelectuais, sensoriais, afetivos, emocionais, relacionais.

Assim a escrita chega aos olhos da criança e do adolescente quando estes andam pelas ruas ou estão em casa, na sala de aula (textos escolares), na biblioteca escolar (quando existente). No caso de crianças em situação de abrigo a escrita lhes chega também através de padrinhos que visitam a Instituição ou, ainda, através de um pequeno acervo que esta possa eventualmente ter. 
A criança que vive nos abrigos tem, atualmente, limitações institucionais e de outras ordens para frequentar a biblioteca pública, os centros de cultura e outros espaços situados além do próprio abrigo. No caso de haver uma biblioteca ou um canto de leitura no abrigo, sua necessidade de acesso será atendida em medida, mesmo que restrita. Então, o livro a ser lido, dependendo das mediações feitas, poderá ser levado para o espaço escolhido pela criança, fornecendo-se, assim, a experiência daquilo que Manguel $^{22}$ chamou de "um lar permanente, por mais estranho que seja o quarto em que se está". Ler, nesse sentido, é delimitação e apropriação de um espaço próprio, intransferível e que pertence definitivamente ao leitor.

Por outro lado, ao ler, o indivíduo interpreta a escritura, baseado em si e em seu repertório. Nesse processo, sua leitura perfaz caminhos, recortando, selecionando e relacionando os elementos necessários à interpretação. O leitor é assim atravessado e transitado pela obra, ao mesmo tempo em que a atravessa e transita, apropriando-se da proposta do autor, recriando-a, refazendo-a em termos próprios e, ao mesmo tempo, do outro.

Presença, a leitura coloca sujeitos em comunhão. Ausência, os leitores estão irremediavelmente a sós em suas lutas com a escritura. E nessa ambiguidade fundamental, segundo Proust ${ }^{23}$, entre esse estar e não estar emergem os sentidos, as significações. O leitor travará batalhas consigo, com os personagens, com o autor, viajará por terras, transpondo fronteiras, ceifando em campos que pertencem a outros $(\text { Certeau })^{24}$, nos quais não plantou, mas que cultiva e é por eles cultivado. Esse viajante ainda se irrita, se alegra, se entristece, se nega e renega. Retorna ao seu contexto, portanto, modificado.

A leitura apresenta-se, assim, como um dispositivo capaz de potencializar efeitos de après-coup a partir dos quais um sujeito será capaz de produzir saber inconsciente ao inventar-se a cada nova configuração de sentido, sem prescindir das referências iniciais que the permitem ler o seu desejo e o desejo do Outro a partir do qual ele se constitui. (TOROSSIAN, 2005, p. 77).

\footnotetext{
22 MANGUEL, Alberto. Uma história da leitura. São Paulo: Companhia das Letras, 1997.

${ }^{23}$ PROUST, Marcel. Sobre a leitura. Campinas: Pontes, 1991.

24 As relações sociais sobredeterminam as relação com os textos. CERTEAU, Michel. de. $A$ invenção do cotidiano. Petrópolis: Vozes, 1994.
} 
Tomada, pois na perspectiva exposta, a leitura não se apresenta como mera decodificação de sinais, gesto mecânico de reconhecimento de marcas que não transcendem e ultrapassam o nível meramente físico dos signos. Tal compreensão, como já mostraram inúmeros autores, de diferentes procedências, como, por exemplo, Freire e Ferreiro ${ }^{25}$, reduzem a leitura a mero jogo mecânico, sem se dar conta de suas dimensões simbólicas que caracterizam os atos de significação (BRUNNER, 1997).

É, pois, neste último sentido que tomaremos a leitura. Como já observamos, no caso dos abrigos, a questão física, material do acesso é relevante. As vias estão bloqueadas, mesmo considerando-se os parcos recursos culturais da cidade. Por outro lado, a estrutura do Abrigo já traz consigo obstruções importantes aos processos de significação, envolvendo mais que a relação física e capacidades de decodificação. As vivências na cidade, em seus diferentes espaços urbanos são, em geral, difíceis, dadas as condições das crianças e dos abrigos.

Foi, todavia, por conta dessas dificuldades que nos propusemos a desenvolver oficinas de leitura com as crianças e adolescentes em situação de abrigo. Entendíamos que, dadas suas características de presença na ausência, a relação com a escrita poderia permitir a essas crianças experiências de dialogismo e de protagonismo que são essenciais a quaisquer crianças, independentemente da situação em que se encontram:

[...] O que 'constitui minha autoconfiança interior, fortalece minhas costas, ergue minha cabeça e dirige meu olhar para frente' é o conhecimento de que 'o verdadeiro centro de gravidade de minha autodefinição está no futuro' e sempre há de estar no futuro. (MORSON, 2008, p. 210, citando Bakhtin).

A dialogia nos remete ao encontro, à vida, ao movimento, ao contínuo, a um presente imbricado em memória apontando para o futuro. Nesse sentido, talvez o abrigo pudesse ser uma estação que acolhe aos viajantes e os lança em vias cujos destinos estão abertos e são imponderáveis. Refúgio, como pretende Petit ${ }^{26}$, a leitura pode assim ser também projeção, vale dizer, experiência que se estende em direção ao futuro.

\footnotetext{
${ }^{25}$ FREIRE, Paulo. Pedagogia do oprimido. Montevidéu: Terra Nova, 1990. FERRERO, Emilia. Cultura, escrita e educação. Rio de Janeiro: Artmed, 2000.

${ }^{26}$ PETIT, Michèle. Os jovens e a leitura: uma nova perspectiva. São Paulo: 34, 2008.
} 
Assim, além de espaço, a leitura é também tempo, considerada em suas possibilidades múltiplas e diversas, e que não estão fechadas, mas abertas às surpresas e à criação.

\subsection{Leitura e dispositivos: a oficina de leitura}

Ser significa comunicar-se dialogicamente.

Quando termina um diálogo, tudo termina.

Todorov

Do latim officina, o termo oficina refere-se ao lugar onde se exerce um ofício. Do ponto de vista figurado, no entanto, remete ao lugar onde se verificam grandes transformações. (AURÉLIO, 1975, p. 993). Ao adotarmos as oficinas de leitura, como estratégia metodológica de nossa pesquisa, tínhamos em mente esses dois significados, por serem eles pertinentes aos nossos objetivos, bem como por corroborarem com o que entendemos por leitura (termo tratado adiante).

Assim sendo, podemos afirmar que a Oficina de leitura é um lugar físico. Todavia, mais que isso, além de um lugar físico, ela é também, e especialmente, lugar simbólico, ambiente. Ali, sujeitos se encontram e descobrem nas ações desenvolvidas em torno da leitura, a própria leitura; descobrem motivações e significações, possibilidades de se posicionarem de maneira criativa, crítica e produtiva diante de textos informativos ou literários, bem como das variadas modalidades textuais que perpassam as suas realidades, sejam as orais, audiovisuais, gestuais, presenciais, eletrônicos, dentre outras. Na Oficina de leitura, tal como a concebemos aqui, os sujeitos, descobrem a leitura e, nesse processo, se descobrem e redescobrem, num processo contínuo, crescente e recíproco de desvelamento de si e do outro, aprendendo não só a decifrar textos, mas a ler o mundo, o outro e a si próprio.

As oficinas de leitura são, nesse sentido, concebidas como dispositivos culturais com o objetivo de conferir às crianças e aos adolescentes a oportunidade de exercitarem suas condições necessárias de protagonistas culturais nas relações com o patrimônio 
literário disponibilizado nas sessões que as compõem. Sendo assim, um conjunto de enunciados foi apresentado e descoberto nos mais diferenciados elementos que constituem o dispositivo. Foram muitas as surpresas, as revelações, desde os objetos colocados em cena até as falas dos participantes, seus gestos, suas roupas e interesses.

Nesse sentido, havia um sussurro anônimo ${ }^{27}$ atuando nas interações e nos significados gerados pelas atividades realizadas nas oficinas: tratava-se do sussurro do dispositivo cultural que comunicava dialogicamente na esfera do inter-humano, do face a face.

As oficinas de leitura, nos termos aqui definidos, propõem-se, assim, como dispositivo cultural necessário e inerente aos atos simbólicos, concebido, todavia, como espaço e tempo de busca, de negociação, de apropriação e construção de sentidos, envolvendo em tais processos investimentos e engajamentos de diversas ordensafetivas, intelectuais, emocionais, sensoriais, dentre outros-, inscritos nos atos cognitivos.

\section{3. $O$ conceito de dialogia}

Ainda não aconteceu nada de conclusivo no mundo, a última palavra do mundo e sobre o mundo ainda não foi dita, o mundo é aberto e livre, tudo ainda está no futuro e sempre há de estar no futuro.

Mikhail Bakhtin

O ser humano se constitui e constitui o outro pela ação e pela linguagem, isto é, em interação com o outro e com o mundo, tomados tanto como instâncias físicas como simbólicas. No entanto esse constituir-se social e individualmente apresenta-se sempre como porvir, descortinando-se em dialogia, no eu, na cultura, na linguagem, na rica

${ }^{27}$ DELEUZE, Gilles. Foucault. São Paulo: Brasiliense, 2006. 
textura da vida prosaica, do trivial ao surpreendente, implicando tanto liberdade quanto responsabilidade.

[...] A forma singular adequada para a vida humana autêntica que se expressa verbalmente é o diálogo aberto. A vida, por sua própria natureza, é dialógica. Viver significa participar de um diálogo: fazer perguntas, prestar atenção, responder, concordar e assim por diante. Nesse diálogo, uma pessoa participa totalmente e com toda a sua vida: com olhos, lábios, mãos, alma espírito, com todo o seu corpo e todas as suas ações. Ela investe todo o seu eu no discurso, e esse tecido entra no tecido dialógico da vida humana, no mundo do simpósio. (BAKHTIN, apud MORSON, 2008, p. 78, itálico do autor).

No mundo do simpósio, estabelecemos diálogos, parcerias constituídas no caminhar junto, seja por meio de narrativas pessoais sobre acontecimentos do dia a dia, por meio de leituras sobre acontecimentos distantes ou outras formas discursivas que nos permitem entrar em relação com o outro.

Para Bakhtin, as relações dialógicas vão além de meras réplicas em um diálogo. Segundo ele, trata-se de um modo de produção de si e do outro, “[...] um fenômeno quase universal, a permear todo o discurso humano e todas as relações e manifestações da vida humana - em geral, tudo quanto tem sentido e significação.” (BAKHTIN, apud MORSON, 2008, p. 67).

Se buscamos a construção de significados, a apropriação simbólica de bens culturais e a protagonização de atores aí envolvidos, encontramos na dialogia uma característica compatível com tal pretensão: seu caráter de não-finalizabilidade ${ }^{28}$. Nesse sentido, a dialogia não pode ser entendida como um sistema, um fluxo, porque requer de cada ator envolvido a participação responsiva e lhe confere a liberdade de ser-emrelação-ao-outro, ou seja, ser em construção permanente do mundo, o grande acontecimento.

A situação dialógica não implica perda de individualidade. Ao contrário, a afirma, na medida em que requer o reconhecimento mútuo da responsabilidade ${ }^{29}$ de cada um na relação. Sendo assim, é importante ressaltar que a presente pesquisa cultiva no momento da mediação cultural e no espaço em que ela acontece, possibilidades

\footnotetext{
28 '[...] inovação, 'surpreendência', o genuinamente novo, abertura, potencialidade, liberdade e criatividade. [...]” (MORSON, 2008, p. 55)

29 "O conceito de responsabilidade precisa ser recambiado, do campo da ética especializada, de um 'dever' que flutua livremente no ar, para o domínio da vida vivida. Responsabilidade genuína só existe onde existe o responder verdadeiro".(BUBER, 2007, p. 49).
} 
dialógicas, embora esta não signifique aqui ausência de silêncios que caracterizam todos os atos de comunicação. O que está em causa é a superação da monologia, segundo a define Bakhtin. Para ele, a monologização, em sentido amplo, "[...] converte o diálogo em forma vazia e interação sem vida."30 Trata-se de um modelo reificado, previsível, desenraizado do mundo e sem potencialidade de criação.

Considerando-se as condições específicas dos abrigos, algumas questões relevantes são colocadas à mediação cultural pautada pela dialogia. Como pudemos verificar, à medida que a pesquisa avançava, exigências decorrentes das características contextuais colocavam-se a nós, obrigando que pensássemos a dialogia não apenas como um conceito abstrato, mas ao contrário, como uma prática contextualizada e definida em relação a esta categoria.

Devido a tais questões, tivemos assim que desenvolver ações de mediação que personalizassem os sujeitos envolvidos, conferindo-lhes identidade própria, reconhecimento especial de cada um, já que as condições de vida que levaram as crianças ao abrigo, bem como as dinâmicas ali ainda prevalentes, trabalham em sentido contrário. O sentimento de anonimato, de não pertencimento, de não diferenciação é forte em crianças em situação de abrigo e, em decorrência, era necessário trabalhar com práticas e concepções culturais que fossem em sentido contrário.

Se observarmos os repertórios informacionais, os textos escritos, as obras de cultura e arte, bem como as apropriações simbólicas sob o prisma da dialogia, devemos observar, também, que as mediações culturais envolvidas nestes processos devem ser pautadas pelo mesmo critério. Tais ações necessitam se fazer na medida do caminhar junto, do estar presente $e^{31}$ no percurso.

Nosso percurso se deu, portanto, em um abrigo para meninos e meninas de zero a dezoito anos, no interior de São Paulo, onde à medida que a mediação cultural dialógica ia ocorrendo, termos relacionais foram surgindo e se apresentam aqui como um quadro histórico que nos fornece as bases para construções teóricas e operacionais.

\footnotetext{
${ }^{30}$ MORSON, Gary Saul; EMERSON, Caryl. Mikhail Bakhtin: criação de uma prosaística. São Paulo: EDUSP, 2008. p. 75.

31 ' $[. . .$. Presente como oposto ao passado e ao futuro e presente como 'em presença de'. O presente como momento presente transcende de algum modo o puro instante unidemensional na intersecção de duas facções do tempo. O presente em Buber evoca-nos o 'instante' kierkegaardiano que é decisivo e pleno de eternidade; ele é a plenitude dos tempos. [...] presentidade.” (BUBER, 1979, p.159, nota do tradutor)
} 


\subsection{Protagonismo cultural}

O termo protagonismo provém do grego, formado do prefixo próton, que significa principal, primeiro e de agon, isto é, luta. O protagonista, no teatro grego luta, ou seja, é o principal lutador. Sua luta, contudo, está inserida nos interesses coletivos da polis. Desse modo, o protagonista é alguém conectado e profundamente vinculado ao seu mundo, diferentemente do herói individualista que a modernidade forjou, em especial, o romantismo e seu ideal de $e u$ apartado da sociedade.

Dada tal derivação, o protagnistés grego é um lutador que ocupa um lugar de destaque, pois concentra e representa a coletividade e suas exigências de sobrevivência e permanência que ultrapassam os limites estreitos do pessoal e do privado. Ao ocupar o primeiro lugar num acontecimento, o protagonista não afirma apenas a si próprio, mas encarna os interesses gerais da polis, em geral, em oposição ao despotismo, isto é, a prevalência de interesses privados sobre os públicos.

A partir dessa concepção grega, portanto, é que estaremos tomando nesta dissertação o conceito de protagonismo cultural para nomear ações que se constituem, se definem e "[...] ganham significado tão somente na dinâmica viva e constante existente entre as forças do particular e do geral, do individual e do coletivo." (PERROTTI, 2007, p. 78). Nesses termos, o protagonismo, aqui referido deriva de uma abordagem cultural - de uma investida no âmbito da cultura para crianças e adolescentes em regime de abrigo, a partir das oficinas de leitura que consideram tanto o aspecto do grupo, da coletividade, como, e principalmente, o aspecto da individualidade, do pessoal com ele em diálogo e não em oposição.

Importante é deixar claro que, segundo a ótica por nós adotada, o objetivo de qualquer mediação será a autonomia, a emancipação e a participação ativa dos sujeitos nos processos de diferentes naturezas em que se acham envolvidos, o que os caracteriza, consequentemente, como protagonistas de tais ações.

Em primeiro lugar, convém ressaltar que a mediação cultural dialógica a que nos referimos aqui não é tratada apenas em sua dimensão metodológica ou instrumental de procedimentos necessários à formação de protagonistas culturais. Se ela parece ter potencialidades nesse sentido, ela não se esgota, contudo, nessa dimensão estratégica, instrumental. Ou seja, a mediação cultural é uma categoria de natureza filosófica 
constitutiva, ela própria vem a ser como ação dos envolvidos na condição de protagonistas. Fazer uma 'investida dialógica' é envolver-se efetivamente na interlocução cultural, é compartilhar questões e problemas de diferentes ordens, é interagir, entrar em relação, em negociação de sentidos. A partir do momento em que os envolvidos se dispõem ao diálogo, assumem uma responsabilidade com os quais se relacionam, bem como com os processos e objetos constitutivos da interlocução. Dessa forma, mediar cultura na perspectiva dialógica desta dissertação é um ato de colocar em relação protagonistas e repertórios culturais, tornando-se nesse processo o mediador, como os demais envolvidos, também protagonista, sujeito cultural atuante e participante dos processos cognitivos e socioculturais que o envolvem.

\section{O conceito de abrigo}

"Todo eu tem remendos ritmicizados, é claro, porque a alma nos é propiciada continuamente. Mas esses remendos estão eles próprios sempre mudando. Assim, uma atitude de 'esperança' nesse sentido não precisa implicar uma fé no aprimoramento; implica simplesmente a certeza de algum tipo de mudança significativa."

MORSON

No século XVIII, começou a surgir literatura na França sobre o tema da guarda de crianças em instituições especiais. No geral, essa literatura questiona “[...] os costumes educativos de seu século, tendo em vista três alvos privilegiados: os hospícios de menores abandonados, a criação dos filhos por amas-de-leite e a educação 'artificial' das crianças ricas. [...]” (GUIRADO, 2004, p. 33).

No Brasil, a Lei do Ventre Livre, a abolição dos escravos e, mais tarde, a industrialização jogaram um grande contingente de pessoas nas ruas. As medidas tomadas, em relação a essas pessoas, não foram, segundo Souza Neto, para defendê-las, mas sim uma maneira de proteger a ordem social vigente, pois tais crianças e jovens ociosos e excluídos eram vistos como elementos perigosos pela ordem reinante. A infância abandonada é, considerada, assim, um desvio social que necessita ser corrigido. 
No final do século XIX, de acordo com João Clemente de Souza Neto, quando um número crescente de crianças é abandonado nas grandes cidades, como São Paulo, escandalizando a opinião pública, surgem as Santas Casas de Misericórdias com as rodas dos expostos onde se depositava os enjeitados. Vale lembrar também que a Lei do Ventre Livre, primeira lei dirigida à proteção da infância, acabou voltando-se contra esta, ao eximir o proprietário de escravos de que cuidar da criança nascida livre. Da mesma forma, a responsabilidade criminal da criança, inscrita nos Códigos de 1820, 1890 e 1927 " [...] reproduziam ranços da lei do pobre, apresentando o confinamento como solução de continuidade para a miserabilidade infanto-juvenil. [...]" (SOUZA NETO, 2001, p. 93).

No reverso dessas experiências negativas, mesmo se em números estreitos, vem também experiências bem-sucedidas de atendimento à criança, segundo Souza Neto. Contudo, segundo ele.

[...] o que prevalece nas práticas de atendimento assistencial da época é a concepção do 'menor' como ser sem desejos e vontades, objeto de ações religiosas e políticas. A assistência ganha prioridade como instrumento de manutenção e não aparece como coadjuvante da vida da população carente. (SOUZA NETO, 2001, p. 94).

Da dinâmica das esferas sociais, políticas e econômicas surge, então, essa preocupação com a camada da população que não é absorvida pelos ideais de vida e de sociedade então em construção no país e que necessitam de assistência para que a ordem social não seja perturbada. Assiste-se, assim, no país, o surgimento de profissões voltadas ao atendimento de crianças e adolescentes abandonados ${ }^{32}$, formando-se com o tempo um aparato significativo de especialidades, composto de juízes da infância e juventude, de procuradores da justiça, educadores, assistentes sociais, líderes comunitários, conselhos tutelares, dentre outros.

A promulgação do Estatuto da Criança e do Adolescente - ECA, em 1988, permite nascer entre nós um novo conceito de abrigo e que, ao menos teoricamente, se caracteriza pela "[...] garantia de atendimento personalizado e de respeito à identidade

\footnotetext{
32 O termo abandono “[...] refere-se à situação da criança que deixou de ser atendida em suas necessidades por parte dos pais. [...]" (CENTRO, 2002, p, 20) Segundo Bierrenbach “[...] em lato-senso são aqueles privados dos direitos básicos. No estrito-senso, significam que não contam com pai, mãe ou responsável em condições psicológicas, morais ou econômicas para suprir suas necessidades. [...]" (SOUZA NETO, 2001, p. 19).
} 
dos usuários, com instalações físicas adequadas, salubridade, segurança, educação e cuidados médicos e psicológicos. [...]” (SOUZA NETO, 2001, p. 94, grifo nosso) Trata-se aqui de um vislumbre, de uma possibilidade de concretização de políticas voltadas para a infância cujo objetivo seja colocá-la no circuito de cidadania.

O que se pretende, antes de qualquer coisa, é que a criança retorne à sua família biológica. Porém, o tempo que tal família leva para se reestruturar pode ser longo, tornando o provisório permanente.

[...] no Brasil nunca se fez muita distinção entre abrigo, orfanato e internato. [...] Mesmo sem definir precisamente o que seja um 'internato', o ECA parece ter incorporado a noção mais popular, determinando, no parágrafo primeiro de seu Artigo 121 que a 'a internação constitui medida de privação da liberdade'. Assim, convencionou-se, no Brasil, a associar abrigo com medidas de proteção e internato com medidas sócio-educativas. (CENTRO, 2002, p. 103).

$\mathrm{O}$ abrigo $^{33}$ no qual se realizou essa pesquisa é um lugar de permanência prolongada, do tipo casa-lar, porém sem a figura da mãe social. Os agentes presentes na institucionalização das crianças e dos adolescentes são juizes, promotores, Conselho Tutelar, Conselho Municipal dos Direitos da Criança e do Adolescente.

Considerando o abrigo “[...] um espaço de possibilidade da produção do sujeito criança e adolescente - privado dos direitos sociais, de articulação entre a objetividade e a subjetividade [...]" (SOUZA NETO, 2001, p. 24) como se daria essa produção do sujeito? Souza Neto indica como saída o transviver defendendo a existência de um

[...] espaço de manobra entre o mundo e o sujeito, no qual ele manifesta seus desejos, suas pulsões e faz previsões e escolhas racionais. As ações do sujeito são encaminhadas dentro desse movimento que joga o indivíduo para o encontro do outro e lhe propicia condições para a autodescoberta. (SOUZA NETO, 2001, p. 77).

Nesse transviver, a constituição do sujeito se dá simultaneamente nas redes onde se constrói seu cotidiano, permitindo assim, objetivação e subjetivação, muitas vezes implicadas no que fazer para sobreviver, ou seja, em estratégias. Nestas se ancoram a criatividade, a inventividade e a dialogia necessárias à vida. Ora, se compreendemos o abrigo como um dispositivo, então, devemos considerar tanto sua materialidade, como

\footnotetext{
${ }^{33}$ Para classificação ou modalidades de abrigo ver anexo.
} 
sua dimensão simbólica. Ele é, portanto,, causa imanente capaz de se transformar pelas próprias ações, transformando, em conseqüência o agir, o pensar e o sentir das crianças e dos adolescentes que ali convivem.

Assim como o abrigo deixa suas marcas nas crianças, igualmente as crianças deixarão as suas marcas nesse espaço. As crianças e os adolescentes não apenas vivem nesse espaço, mas vivem esse espaço de maneira intensa, apesar de, muitas vezes, tensa. Em que pesem, portanto, condições adversas, acham-se nos abrigos, tal como ocorre nos demais espaços sociais, sujeitos com anseios e condições de se tornarem protagonistas da própria vida e, nas dimensões do possível, dos embates que afetam a polis, lugar de onde se acham excluídos, mas não alheios.

As observações de Martin Buber sobre as instituições e os sentimentos jogam luz sobre as tensões e contradições observáveis nos abrigos:

\begin{abstract}
As instituições são o "fora", onde se está para toda sorte de finalidades, onde se trabalha, se faz negócios, se exerce influência, se faz empreendimentos, concorrências, onde se organiza, administra, exerce uma função, se prega; é a estrutura mais ou menos ordenada e aproximadamente correta na qual se desenvolve, com o concurso múltiplo de cabeças humanas e membros humanos, o curso dos acontecimentos.

Os sentimentos são o "dentro", onde se vive e se descansa das instituições. Aí o espectro das emoções vibra diante do olhar interessado; aí o homem usufrui sua ternura, seu ódio, seu prazer e sua dor, quando esta não é muito violenta. Aí a gente se sente em casa, se estira na cadeira de balanço. (BUBER, 1979, p. 50-51).
\end{abstract}

Os movimentos contraditórios dos abrigos, as oposições irreconciliáveis entre o dentro e o fora, a ordem monológica que em geral aí impera, que exclui a diferença, a diversidade, o outro, a alteridade, criam dilemas e hiatos insuperáveis entre a lógica da instituição e a dos sujeitos/sentimentos que aí se encontram, entre a proteção e a autonomia, entre o cuidado e o desejo de liberdade e de afirmação de si.

A concepção dialógica da mediação cultural está diretamente relacionada ao protagonismo, ao reconhecimento de sujeitos que, ao atuarem, não só constroem, mas nomeiam o mundo, imprimindo-lhe, portanto, sentidos e direções. 


\subsection{Dialogia, memória e futuro}

Ao ler o relato da vida da Esmeralda em seu livro "Porque não dancei", observase não somente o trajeto da vida dela, mas todo o contexto "macro" no qual sua vida "micro" estava envolvida. Podemos observar ali linhas de forças atuando transversalmente através de movimentos político-sociais. A importância de se situar dentro da própria história para poder dar continuidade à própria vida.

Esses fatores não são diferentes nas vidas de outras crianças e adolescentes em situação de abrigo, cuja condição, como qualquer outro cidadão, se faz, necessariamente, no presente, um presente aparentemente sem amarras, desvinculado do passado e sem pretensões para o futuro. Esses fatores como outros são trabalhados e levados em consideração por alguns abrigos, mas diante das leituras, de algumas vivências e outros relatos, há muito que se caminhar.

Em virtude da relação personalizada que a presente pesquisa propõe, com crianças e adolescentes, objetivando o protagonismo dos mesmos na utilização de dispositivos informacionais e culturais, é que temos que abordar, de certa maneira, a questão da memória e o que ela representa para essas crianças.

O dicionário define 'memória' como faculdade de reter as idéias, impressões e conhecimentos adquiridos anteriormente: lembrança, reminiscência, recordação; vestígio, lembrança, sinal; aquilo que serve de lembrança. (AURÉLIO, 1975, p. 910).

Segundo Giulia Crippa, a memória é:

[...] uma força de conexão, estabelece relações, preserva alguns elementos, mas vai além da preservação: faz viver, portanto, tende a fazer crescer, por quanto permitido ao homem, já que o tempo sempre destrói alguma coisa; a memória é o diálogo com a temporalidade. Imaginação e Memória são faculdades ligadas ao tempo e ao sentido de tempo, que é a capacidade de transcender ao presente. $\mathrm{O}$ homem sem memória e sem imaginação viveria um eterno presente que se repete, como os animais. $\mathrm{O}$ homem vê a si mesmo porque lembra e antecipa. (CRIPPA, 2007, p. 122).

No caso das crianças em situação de abrigo, tais lembranças se dão a partir de traços de familiaridade os quais são reconhecidos por meio do "[...] toque (memória cinestésica), do cheiro (memória olfativa), da voz e dos sons (memória auditiva) e do 
espaço (memória espacial). [...]" (CENTRO, 2002, p. 46). Podemos acrescentar aqui que, em relação a dispositivos informacionais e culturais, essas lembranças incidem sobre o que se apresenta na memória de cada um e, à medida que se "acerta uma paisagem memorial", esta provoca uma série de reações, desde reflexões, passando por associações, ou mesmo por um fechar-se-para-si. Temos na memória, portanto, um lugar de recepção, de armazenamento de informações que atua diretamente no seu processamento e, principalmente, nos processos de apropriação simbólica de bens culturais. Ao se perceberem no que produzem, a criança e o adolescente dizem: "eu fiz", "olha fui eu que fiz". Os olhos do outro conferem existência ao "eu"; existir aos olhos do outro representa uma medida que pode, muitas vezes, determinar o nascimento, o crescimento e, em sentido inverso, o falecimento:

[...] muitas crianças, tendo o abrigo como único socializador e referência de sua infância, especialmente na fase da adolescência, entram num processo de sofrimento intenso, desejando reconstruírem sua história, buscando informações sobre familiares, fotos de quando eram bebês, etc. Muitas vezes não encontrando nada, ficando somente um vácuo desse período." (CENTRO, 2002, p, 30).

A sujeição da criança e do adolescente ao abandono, à criminalidade está associada, dentre outros fatores, a essa memória ou, ao seu avesso, o esquecimento. $\mathrm{Na}$ mesma proporção que temos necessidade de lembrar, temos também a necessidade de esquecer, já uma ação não anula a outra. O importante, no entanto, é estarmos cientes de que quando trabalhamos com qualquer pessoa, independentemente de gênero, raça, ou faixa etária, estamos, antes de qualquer coisa, lidando com a condição humana, nos termos referidos por Hannah Arendt ${ }^{34}$. Condição complexa, não se reduzindo aos atos impensados ou de consumo acrítico e mecânico, mas à uma vida ativa e contemplativa.

Foi nesse sentido que nos deparamos com a necessidade de instrumentos que pudessem ser ao mesmo tempo pesquisa e ação educativa e cultural, prática científica e profissional que se alimentam dinâmica e reciprocamente. Encontramos na metodologia colaborativa a dialogia ciência/sociedade que buscávamos a partir do sentido harendtiano da vita activa.

\footnotetext{
34 vida ativa concebida por três atividades humanas fundamentais, a saber: labor (processo biológico, necessidades vitais), trabalho (produção do artificial) e ação (atividade que se exerce diretamente entre os homens) e esta “[...] cria a condição para a lembrança, ou seja, para a história. [...]”.(ARENDT, 2008, p. 15-17).
} 


\section{Parte B}

Metodologia 


\title{
1. Metodologia Colaborativa
}

\begin{abstract}
Descobertas e revoluções no mundo da ciência sempre determinaram profundas modificações na esfera da arte, para a seguir serem transpostas, através de um labor de mediações e de penetração em nivel intelectivo, ao terreno da organização da sociedade como um grupo.
\end{abstract}

CUTOLO

Este trabalho serve-se da metodologia de pesquisa colaborativa ${ }^{35}$, tal como vem sendo proposta nos quadros do ColaborI $^{36}$ - Colaboratório de Infoeducação do Departamento de Biblioteconomia e Documentação - ECA/USP. Trata-se de uma escolha que se alinha à natureza do objeto de pesquisa que tem seu foco na problemática da apropriação social das informações e dos bens culturais em suas relações com processos educativos, vistos como condição de protagonismo cultural.

O termo colaborativo indica um trabalho (ou a participação em obra científica) em comum com uma ou mais pessoas de diferentes procedências acadêmicas e profissionais. Nesse sentido, a metodologia colaborativa, nos termos propostos, incorpora ao fazer científico a complexidade do "tecido em conjunto"; os preceitos e princípios da transdisciplinaridade ${ }^{37}$, dos saberes plurais ${ }^{38}$, e dos intersaberes ${ }^{39}$. Em seu cerne está a abordagem qualitativa relacionada aos estudos interpretativos e culturais,

35 PERROTTI, Edmir; PIERUCCINI, Ivete. Infoeducação: saberes e fazeres da contemporaneidade. In: LARA, M.; FUJINO, A.; NORONHA, D. P. (Org.). Informação e contemporaneidade: perspectivas. Recife: Néctar, 2007. p. 47-96.

${ }^{36}$ O conceito de Colaboratório surgiu em 1989, em um seminário da National Science Foundation (EUA), quando William Wulf definiu o laboratório em rede como um 'centro sem paredes'. Neste conceito está alocado, junto com o desenvolvimento tecnológico, "[...] um modo de interação entre pesquisadores científicos mobilizando vastas quantidades de informação e recursos computacionais, indo além da compartimentação geográfica." (SCHWARTZ, 2006, p.2). A National Science Foundation apresenta ainda algumas condições para que tal modelo de pesquisa se realize. Dentre eles, destacamos dois essenciais ao desenvolvimento deste trabalho: 1. Ter certeza de que a comunidade de pesquisa está pronta para assumir esse modelo de trabalho, inclusive no que se refere o compartilhamento de equipamentos; 2. Criar uma linguagem comum, um vocabulário unificador

${ }^{37}$ RANDON, Michel, et al. La pensée transdisciplinaire et le réel, Dervy, Paris, 1996.

${ }^{38}$ MEDINA, Cremilda (org). Caminhos do saber plural: dez anos de trajetória. São Paulo: ECA/USP, 1999.

${ }^{39}$ CHARLOT, Bernard. Da relação com o saber: elementos para uma teoria. Porto Alegre: Artmed, 2000. 
realizados a partir de procedimentos tais como entrevistas, observação participativa, registros escritos e fotográficos, dentre outros, numa aproximação que remete a uma "bricolage" $"$ dos procedimentos.

Os procedimentos metodológicos deste trabalho se fizeram, ou melhor, foram construídos concomitante e paralelamente ao desenvolvimento do mesmo, isto é, a partir da interação entre o campo e a teoria, entre o científico e o empírico, e também na relação com outras pesquisas do ColaborI que adotam a mesma metodologia. Estar vinculada ao um quadro teórico-metodológico torna-se fundamental para dar conta de uma série de informações que vão surgindo no decorrer da pesquisa. Temos, portanto, na metodologia colaborativa adota, a otimização de recursos tanto no campo, como na Universidade, por meio de atividades sistemáticas desenvolvidas no e com as equipes do ColaborI. Tal procedimento metodológico, de natureza dialógica, é, pois, um modo de produção científica que permite mobilizar recursos diferenciados nos processos de conhecimento, aproximando e enriquecendo as buscas, aproximando interesses comuns, sem, contudo, anular ou mesmo "nevoar" as pesquisas específicas de cada um.

Do ponto de vista epistemológico, “[...] a pesquisa colaborativa é a construção de conhecimentos ligados a uma prática profissional dada (que) não se faz sem considerar o contexto real onde esta prática é atualizada. [...]” (DESGAGNÉ, 1997, p.373, tradução nossa). Segundo Desgagné, entre outros aspectos, para se efetivar em suas diferentes dimensões, o projeto colaborativo necessita levar em conta as estruturas organizacionais onde se realiza. (Idem, p.382). As estruturas jurídicas, educacionais e culturais estarão permeando todo o processo e incidindo sobre as práticas ali realizadas.

Nesse sentido, os trabalhos desenvolvidos no Abrigo levam em conta sua organização e modo de funcionamento, considera a posição e as funções ocupadas pelos diferentes sujeitos que aí se encontram da mesma forma que cuida com atenção do lugar ocupado pelo pesquisador, uma vez que este surge como um membro estranho na dinâmica cotidiana da instituição.

Da mesma forma, dadas as características gerais, próprias dos abrigos, será dada atenção especial ao modo de organização das relações, nas oficinas de leitura a serem realizadas. Serão desenvolvidas práticas que privilegiam trabalhos com parceiros, tendo em vista o estabelecimento de relações personalizadas que buscam o reconhecimento da

\footnotetext{
40 "bricoleur", um confeccionador de redes, entrelaçador de métodos e materiais empíricos que estejam ao seu alcance. Termo sugerido por Norman K. Dezin e Yvonna S. Lincoln (2006).
} 
individualidade de cada um, escolha necessária especialmente num contexto em que seres humanos são tratados frequentemente como números que alimentam estatísticas. Dalari chama a nossa atenção para quando se estuda cientificamente a criança:

[...] procura-se a eliminação de tudo o que não pode ser visto, medido ou pesado, uma vez que o tratamento puramente racional se apóia na quantificação e, além disso, são desprezadas características individuais, pois as regras científicas são produtos generalizados [...] não há lugar para os fatores afetivos, para a individualidade da criança e para as condições que a cercam. E assim a criança deixa de ser respeitada como pessoa humana. (DALARI, 1986, p. 24).

As observações de Dalari vão ao encontro do conceito bakhtiniano de dialogia, bem como do conceito e dos procedimentos da metodologia colaborativa adotados, pautados pela ética e a ação responsável, bem como pelo "[...] reconhecimento de que as ações particulares, as pessoas, as épocas e os lugares não podem ser generalizados. (MORSON, 2008, p. 198).

Nesse sentido, a metodologia de pesquisa colaborativa corresponde a procedimentos que trazem necessariamente o discurso do pesquisador e do outro, envolvidos em tramas, em redes que estão na base de processos de apropriação simbólica de construção de conhecimento e de protagonismo cultural.

\section{O Abrigo "Lar Provisório"}

Denominaremos o abrigo onde se realiza a presente pesquisa de Lar provisório ${ }^{41}$. Esse abrigo não é o mesmo que fora mencionado na apresentação deste trabalho, mas um terceiro.

Se, como relatado anteriormente, o primeiro abrigo não acolheu a proposta da pesquisa, o segundo serviu apenas para que eu fizesse a entrada em campo, enquanto cursava a disciplina A Etnografia Aplicada à Pesquisa Educacional. Embora as portas

\footnotetext{
${ }^{41}$ Embora a pesquisa seja realizada em um local real e concreto opinamos por um nome fictício, isso feito para preservar a imagem e a identidade tanto das crianças e adolescentes, bem como do próprio abrigo.
} 
deste abrigo estivessem abertas para a pesquisa, pareceu-me inadequado levar ali o projeto, por três razões: primeiro, o fato de as crianças estarem na faixa etária entre o 00 e 07 anos e eu desejar trabalhar com outras faixas etárias; segundo, as vinculações do abrigo com uma igreja, condição que poderia criar algum tipo de dificuldade intransponível à aplicação do método a que me propunha, por razões religiosas que extrapolam argumentos racionais e se situam no patamar das crenças; e em terceiro, a distância geográfica.

Destinado a meninos de 07 a 18 anos, o primeiro abrigo (local onde se pretendia realizar a pesquisa) possuía uma biblioteca bastante rica em acervos de literatura para adultos, bem como de livros para o público infanto-juvenil, ou seja, havia ali qualidade, quantidade e diversidade. No entanto, em virtude da administração, tais acervos se distanciavam das crianças que para chegarem a eles deveriam enfrentar duas portas trancadas $^{42}$. Por dois anos desenvolvi, nesse abrigo, trabalhos de mediação cultural de diversas maneiras quase sempre sem um retorno expressivo ou abertura da administração que estimulasse ali realizar a pesquisa.

Refletindo e buscando local capaz de atender exigências da pesquisa colaborativa a que me propunha, conheci o abrigo Lar Provisório, localizado em uma cidade ${ }^{43}$ vizinha a Atibaia. No primeiro momento, a assistente social se mostrou reticente. A Prefeitura havia acabado de assumir a responsabilidade pelo abrigo e as crianças estavam agitadas, revoltadas e tensas com todas as modificações que estavam ocorrendo. Segundo ela, não era esse o melhor momento.

Observando as características que este abrigo apresentava: a facilidade de estar lá, meninos e meninas de 0 a 18 anos, trabalho assistencial de cunho educativo e não assistencialista, pessoas novas, com propostas novas, exercendo funções ali... insisti.

À medida que insistia e negociava, uma idéia veio surgindo... não sabia de onde... uma mala de viagens... de livros... de conhecimentos... o conhecimento como viagem...o ônibus pela Fernão Dias... como eu... aquelas crianças, viajando... o abrigo como um ônibus simbólico...

\footnotetext{
${ }^{42}$ Uma porta que separa o corredor da secretaria e da sala e, uma outra que é a da biblioteca.

${ }^{43}$ A cidade possui população estimada em torno de 25.000 habitantes.
} 
Falei da viagem, da mala, da leitura às responsáveis pelo abrigo. Eu seria apresentada às crianças como uma estranha (o que de fato era). As psicólogas que estavam do lado da Assistente Social apoiaram a minha idéia:

- Um elemento a mais agora não faria tanta diferença.

E assim começou a pesquisa/colaboração com o Lar Provisório, quando passei a realizar as Oficinas de leitura, a principio, em grupo, duas vezes por semana (uma hora e meia pela manhã e uma hora e meia à tarde). No entanto quando as oficinas passaram a ser realizadas em parcerias ${ }^{44}$ o tempo investido foi outro, passando assim para 07 (sete) oficinas de aproximadamente uma hora e meia cada ${ }^{45}$ semanalmente e ainda nos reuníamos em grupo pelo menos uma vez por mês.

A experiência de Oficinas de leitura em outro abrigo indicava que o trabalho carecia de tratamento especial, que considerasse o fato de que, em geral, prevalece nos abrigos um tratamento impessoal, todos são tratados coletivamente, sem diferenciações importantes para a construção identitária. As situações anteriores vividas eram claras nesse aspecto, pois as crianças vinham me disputar querendo uma atenção especial, sempre que eu ali ia. De outro lado, o $\mathrm{ECA}^{46}$ já alertava para tal questão, ao preconizar a necessidade e a importância da personalização para as crianças e os adolescentes.

Assim, comecei a idealizar sessões de mediação personalizadas, com oficinas diferenciadas que previam uma atenção especial às características individuais dos participantes. A oficina de leitura foi construída, então, a partir de premissas embasadas na dialogia, mas, ao mesmo tempo, a dialogia era pensada em relação ao contexto específico, ou seja, tratava-se de um conceito que necessitava ser contextualizado, porque o que pode ser dialogia em uma situação, poderá não ser, em outra.

\footnotetext{
${ }^{44}$ Chamaremos aqui de parcerias a formação de grupos de no máximo três participantes que mantenham algumas características comuns, seja de idade, de interesses ou de outra natureza. O grupo pode ser constituído pelas crianças ou por estas e o mediador. Quando os grupos apresentam um número maior que três, as atividades serão referidas como oficinas em grupo.

${ }^{45}$ Ver anexo do cronograma de atividades do abrigo. Diante do cronograma das atividades desenvolvidas com as crianças e adolescentes deste abrigo, podemos observar o quanto eles experienciam outros espaços, não ficando assim confinados no abrigo, ou vivendo apenas o contexto "escola-abrigo".

46 “Art. 92. As entidades que desenvolvam programas de abrigo deverão adotar os seguintes princípios: [...] III - atendimento personalizado e em pequenos grupos [...]” (BRASIL, 1998, grifo nosso).
} 
Por ora, é necessário compreender que contextualizada, a dialogia é vista como categoria dinâmica que coloca em relação sujeitos e repertórios de diversas naturezas, que intercambia espaços e tempos variados, que busca vozes plurais no interior dos discursos que se entrecruzam. Então, alguns elementos foram previamente considerados na preparação das atividades:

a) O espaço e o tempo da Oficina. A oficina é um meio ambiente e, como tal, necessita de cuidados especiais, não podendo ser poluída nem espacial, nem temporalmente.

b) O tamanho do grupo. Como tínhamos preocupações em buscar proximidade, em fazer da leitura um ato de reconhecimento mútuo, entre os participantes, optamos por realizar, preferencialmente, oficinas em parcerias, tal qual definimos anteriormente, isto é, com um número máximo de três crianças ou adolescentes por vez.

c) Grupos por afinidades. Quando não fosse possível a realização de oficinas em parcerias, mesmo assim, o grupo seria composto por crianças com certo grau de identidade de interesses, dado que no contexto dos abrigos nem sempre a aproximação inicial é fácil e os desafios lançados são eles próprios múltiplos, exigindo dos mediadores respostas imediatas de várias ordens, Foi interessante observar que durante a pesquisa, essa formação por afinidades foi ocorrendo de maneira natural, por opção das próprias crianças;

d) Flexibilidade: A mediação embasada na dialogia deveria portar não apenas um plano A, como também um plano B. Em qualquer situação, todavia, devia estar aberta a modificações, em função das negociações que vão sendo feitas no aqui e no agora da Oficina. Evidentemente, em função de objetivos claramente colocados, havia propostas a serem lançadas, caso contrário teríamos um espontaneísmo que estava fora de nossa perspectiva. O dialogismo, no entanto, nos recomendava que as propostas fossem negociadas e, a qualquer momento, abertas a rumos não previstos inicialmente. A experiência anterior mostrava, por exemplo, que certos recursos, certos objetivos, certas estratégias satisfatórios em determinadas situações, eram inadequadas em outra e que tal direção não poderia ser matematicamente definida a priori. A experiência, claro, ajuda muito, mas especialmente nas situações de abrigo, é preciso estar permanentemente atento às demandas do momento. Estas às vezes apresentam uma urgência 
distinta da observada em outras situações. O mediador é, pois, nesse e em outros aspectos, figura destacada do processo. Sua atuação dialógica exige criatividade, capacidade de invenção, disponibilidade para entregar-se aos movimentos sempre surpreendentes que os abrigos apresentam.

e) Acervos: considerado aqui no sentido lato do termo, acervo significa, além obviamente de livros e demais objetos culturais a serem utilizados, como CDs, DVDs, fotos, revistas etc, o acervo das memórias tanto das crianças e adolescentes, como do mediador.

É certo que essas premissas iniciais não se esgotam ai, cada uma delas se abre a inúmeras outras possibilidades, cabe ao mediador, ao contexto, ao universo cultural relacionado e, principalmente, à demanda sugerida pelos ambientes em que a mediação se concretiza, descobrir e potencializar tais possibilidades.

Em relação às práticas de leitura desenvolvidas, partimos de concepções anteriormente expostas e de algumas categorias instrumentais orientadoras, como os movimentos a que se refere Pellanda: de emoções, de invenção, de produção de diferença, de imaginação, de apropriação, de interação e experimentação. (PELLANDA, 2005). 


\section{Parte C}

A Pesquisa 


\section{A mala pronta para viagens a bordo da leitura}

Ao relatarmos a experiência vivida com as crianças do abrigo onde esta pesquisa foi realizada, vêm ao pensamento os rostos de todos os meninos e meninas dos vários abrigos com os quais tive contato, antes deste trabalho. O que eles tinham em comum? $\mathrm{O}$ que buscavam quando me solicitavam algo (como solicitam de qualquer pessoa que se aproxime deles). Talvez tivéssemos algo a oferecer. Se tínhamos, não sabíamos exatamente como oferecer. Qual seria a maneira mais adequada de atingir a todos?

Tudo começou, então, quando decidimos levar uma mala de livros ao abrigo e compartilhá-los com as crianças...

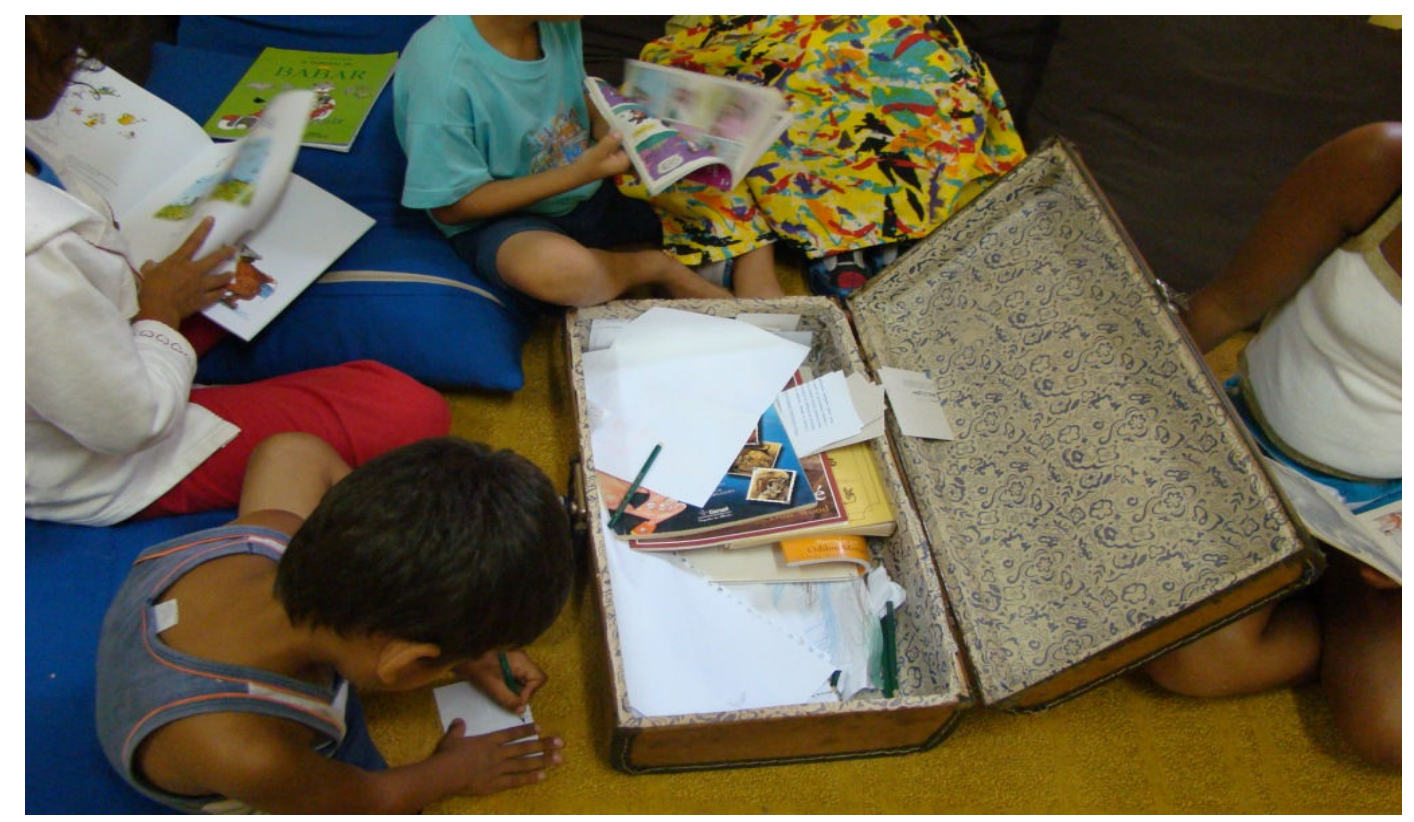

Sônia

Quando adentramos o Abrigo com uma mala antiga, não sabíamos que destinos poderiam estar ali sendo traçados. Guiava-nos a vontade de contato com as crianças, bem como uma descoberta anterior: se é preciso atingir a todos, tenho, no entanto, que atingir cada um na sua individualidade. Os olhares das crianças diziam-me que havia ali desejos de reconhecimento, de atenção, de individualização que precisavam ser atendidos. Só assim poderíamos atingir a todos, em dimensão profunda, vinculadora, 
criadora de laços e de significados. Mal sabíamos quanto seríamos nós mesmos atingidos.

Na mala, pressentíamos, carregávamos muito mais que livros. E, à medida que as ações foram se desenvolvendo, veio a confirmação se deu: a própria mala era um signo, um objeto marginal, não apenas funcional. Segundo a concepção de Baudrillard:

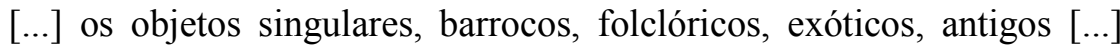
parecem contradizer as exigências do calculo funcional para responder a um propósito de outra ordem: testemunho, lembrança, nostalgia, evasão. Pode-se ser tentado a ver neles uma sobrevivência da ordem tradicional e simbólica. Mas tais objetos, ainda que diferentes, fazem parte eles também da modernidade e dela retiram seu duplo sentido. [...] Todavia não é nem afuncional nem simplesmente "decorativo", tem uma função bem especifica dentro do quadro do sistema: significa o tempo. [...] são os signos, ou indícios culturais do tempo, que são retomados no objeto antigo. Sua presença alegórica não contradiz, portanto a organização geral: natureza e tempo, nada lhe escapa, tudo se efetua nos signos. [...] (BAUDRILLARD, 1993, p. 81-82)

Como ponto de partida, a mala de leituras é um dispositivo que se mostrou dotado de valor simbólico particularmente forte junto às crianças, com a grande vantagem de que ela não depende de outros objetos que não sejam os livros ali guardados. A mala apresenta-se assim às crianças como um objeto mágico, vindo de outros tempos, sabe-se lá de onde. A mala é signo, discurso, recurso emblemático, produtor de deslocamentos.

- Tia, de onde você é?

- Você já viajou muito?

-Você fala outra língua?

A mala e a pessoa que a carrega acontecem numa totalidade em si, totalmente independente do espaço. Tanto é que, a princípio, quando chego, eles não me aceitam:

- Não deixa ela entrar! 
- É, manda ela embora!

- Tudo bem, eu vou. Trago muitas histórias, mas já que não querem ouvir...

deve haver outro lugar com crianças querendo ouvir as muitas histórias que trago na mala...

As crianças, de pronto, responderam:

- Não, não vai não.

- Fica. A gente quer ouvir histórias, sim!

A mala (e sua portadora) chega ao abrigo produzindo espanto. Tanto a mala, quanto os seus conteúdos (livros de diversas naturezas, revistas, gibis) e a sua portadora misteriosa criam um estado de suspensão, de surpresa, de curiosidade que desejávamos provocar ao nos aproximar das crianças, dos adolescentes e de quem mais estivesse por lá. Como algo inusitado ali, naquele espaço, o recurso ofereceu-se como "obra aberta" ${ }^{\prime 4}$, dialógica, que instiga, propicia interações e interlocuções. O estranhamento não gerou uma recusa absoluta, mas, ao contrário, instigou a curiosidade, facilitando o estabelecimento de vínculos.

Os discursos e suas intenções estão contidos nos mais diferenciados suportes: no espaço, nos ambientes projetados para determinadas finalidades, na maneira como as pessoas se vestem e se situam dentro deste espaço. Os objetos, nesse sentido, contracenam e incorporam-se aos sujeitos, formando uma cena total que enuncia ou oculta significados, razões de ser. São, portanto, signos a serem desvendados, “[...] forma(s) significante(s) que o destinatário humano deverá encher de significado. [...]" (ECO, 2005, p.111). Temos então, com a mala, um dispositivo dentro de outros dispositivos, tecendo, articulando propostas e, por outro lado, demandando condutas e padrões de comportamento.

\footnotetext{
${ }^{47}$ ECO, Umberto. Obra aberta. São Paulo: Perspectiva, 2005
} 


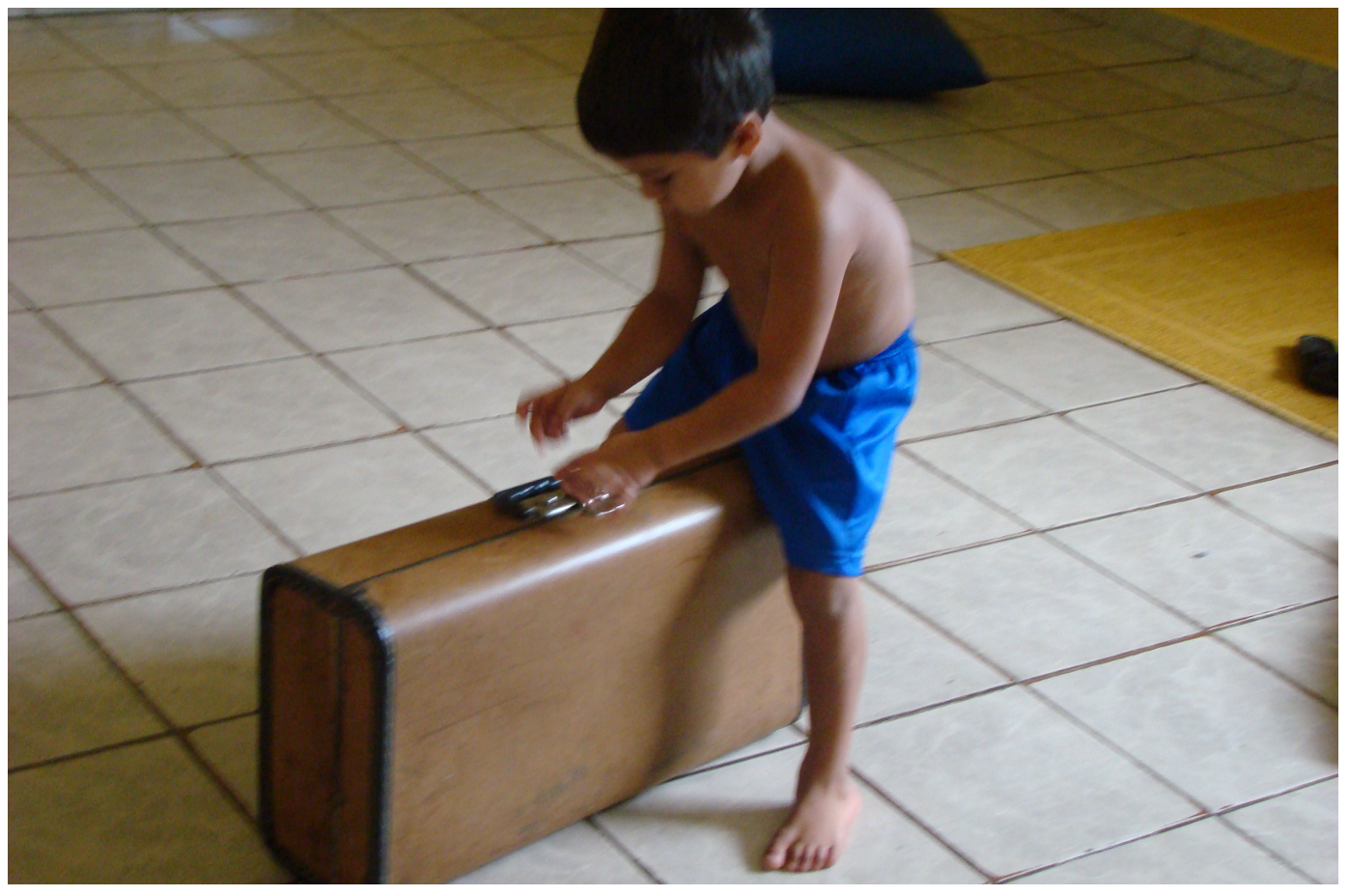

Sônia

Seguindo essa idéia de dispositivos contracenando em cadeia com dispositivos, vale observar que dentro da mala achavam-se livros. A mala era assim um continente no qual se guardavam outros continentes/conteúdos, assim como o são as livrarias, as bibliotecas etc. Nesse sentido, verificamos que anteriormente ao interesse pela leitura, manifestou-se o interesse pela mala, tornada, portanto, conteúdo também. As crianças mostravam interesse em ler o dispositivo, esse objeto-instância que disponibiliza as idéias, fazendo-se, ele próprio no processo, idéia, sentido. No caso dos livros, há a leitura, o interesse pelo desvendamento desses objetos, dessas coisas quase sempre quadradas, retangulares ou com outras formas menos convencionais, com imagens ou sem, às vezes com muitas, outras com poucas páginas, às vezes grandes, outras, pequenas, às vezes com capa dura, outras, quase um folheto.

Assim, pudemos observar, com freqüência, o livro como um objeto significativo, que, pela sua forma, despertava a curiosidade das crianças e também dos adolescentes. Em um primeiro momento, portanto, os livros se apresentam como objetos sensoriais. Por exemplo: Sérgio vê um livro grande, grosso e azul na estante. Pega-o, e diz:

- Olha um livro pra homens!

Depois de folheá-lo, diz, um pouco desapontado: 
- Ah!, não é...

Curioso observar suas expressões. Ele se dirige ao livro como um grande conhecedor daqueles objetos e, pela cor e talvez pelo tamanho do livro, diz ser para homens. Como não encontra figura alguma dentro do livro que confirme suas suspeitas, uma vez que não se trata de um livro editado para crianças, mas para adultos, conclui desapontado que não é para homens.

Muito comum eles quererem vários livrinhos bem pequenos, ou muito grandes. $\mathrm{Na}$ maioria das vezes, livros técnicos de enfermagem ou de engenharia. Essas ocorrências independem, em geral, da idade; dependem mais do grau de alfabetização.

As crianças e os adolescentes do Abrigo que não têm maior familiaridade com o texto escrito, procuram mais que um livro, além de buscar volumes que causem impacto nos outros com quem estão convivendo. O livro aparece para muitos deles não apenas como objeto, mas, sobretudo como marca distintiva que confere identidade e status, mesmo que seja um status imaginado.. Ser portador de um objeto volumoso, que requer aptidões especiais para ser decifrado, é sinônimo de diferenciação e poder.

Com o tempo, as crianças e adolescentes foram convertendo a mala em objeto familiar e significativo Eles traziam livros que, por alguma razão especial, possuíam ou da Biblioteca Municipal, para serem ali guardados. Criavam vínculos e assim se apropriavam do dispositivo. A mala foi então levada para diferentes lugares, posta no porta-malas do carro e transportada até a Biblioteca Pública, o Parque Ecológico, uma praça da cidade, a Casa do Artesão, o Atelier de um artista plástico, o Centro de Informática. Enfim, lugares onde sessões de leitura pudessem ser realizadas. O próprio carro, durante os trajetos, tornava-se oficina de leitura: ouvíamos histórias e música, conversávamos a respeito de pessoas que passavam pela rua, falávamos de assuntos diversos das nossas vidas, líamos uns para os outros.

Como um espaço abrindo espaços, a mala configurou-se logo de início como chave, possibilidade de abertura de um espaço fechado e desconhecido. Fisicamente, a mala era velha, pequena e aparentemente frágil. Todavia, seu espaço interior era permanentemente novo, grande ao acolher livros (infantis e juvenis), revistas, jogos que produziam encantos e encontros então desconhecidos da maioria das crianças. 
Além dos livros, das revistas e dos jogos, a mala tinha espaço para receber materiais escritos produzidos pelas próprias crianças. E ainda mais: em inúmeras situações podia servir de mesa para desenhos e escritas, de banco para sentar, de apoio à cabeça para ver um filme.

Se a mala é signo, um objeto marginal, não funcional que, segundo a concepção de Baudrillard, significa o tempo - falaremos dessa significação mais adiante - é de interesse ressaltar aqui que a mala interagiu com o abrigo muito mais pelo seu valor simbólico, por tudo aquilo que ela representava e gerava, que propriamente por seu valor material e objetual. Aquilo que ela significava deixava margens e aberturas a mais e mais interpretações, fornecendo sentidos novos para ela própria, para os objetos que portava, para os espaços em que se colocava, mas, principalmente, para os atores com os quais interagia. A mala provocava, assim, deslocamentos de sentidos, instaurando processos de ressignificação que renovavam os sujeitos e os contextos em que estes se encontravam:

- Como você chegou aqui? Que tem na mala... Ela é mágica, Tia?

- Como faz para abrir a mala?

- E a mala? Está no carro?

Abri a Mala e disse-lhes:

- Escolham. Cada um pode levar um.

Assim como a mala fora a chave, a permissão, o bilhete de entrada para as vivências com as crianças no abrigo; assim como fora objeto significativo, durante inúmeros processos por nós vividos ali, fora também recurso fundamental no momento que encerrávamos as oficinas previstas para este trabalho e deixávamos o abrigo, sem saber quando e como retornaríamos. Como partir sem alimentar traumas de abandono tão comum nos abrigos?

Resolvemos, então, repartir a mala, para que ela não partisse conosco. A repartição veio por meio de sua metamorfose e multiplicação em diversas sacolinhas que mandamos confeccionar, onde cada um pudesse deixar guardado o livro que receberiam junto com a sacolinha, bem como outros que tivessem interesse. A metamorfose da mala possibilitou a vivência do processo de desvinculação de uma 
maneira sentida, mas sem comoções capazes de alimentar sentimentos de abandono tão comuns nos abrigos.

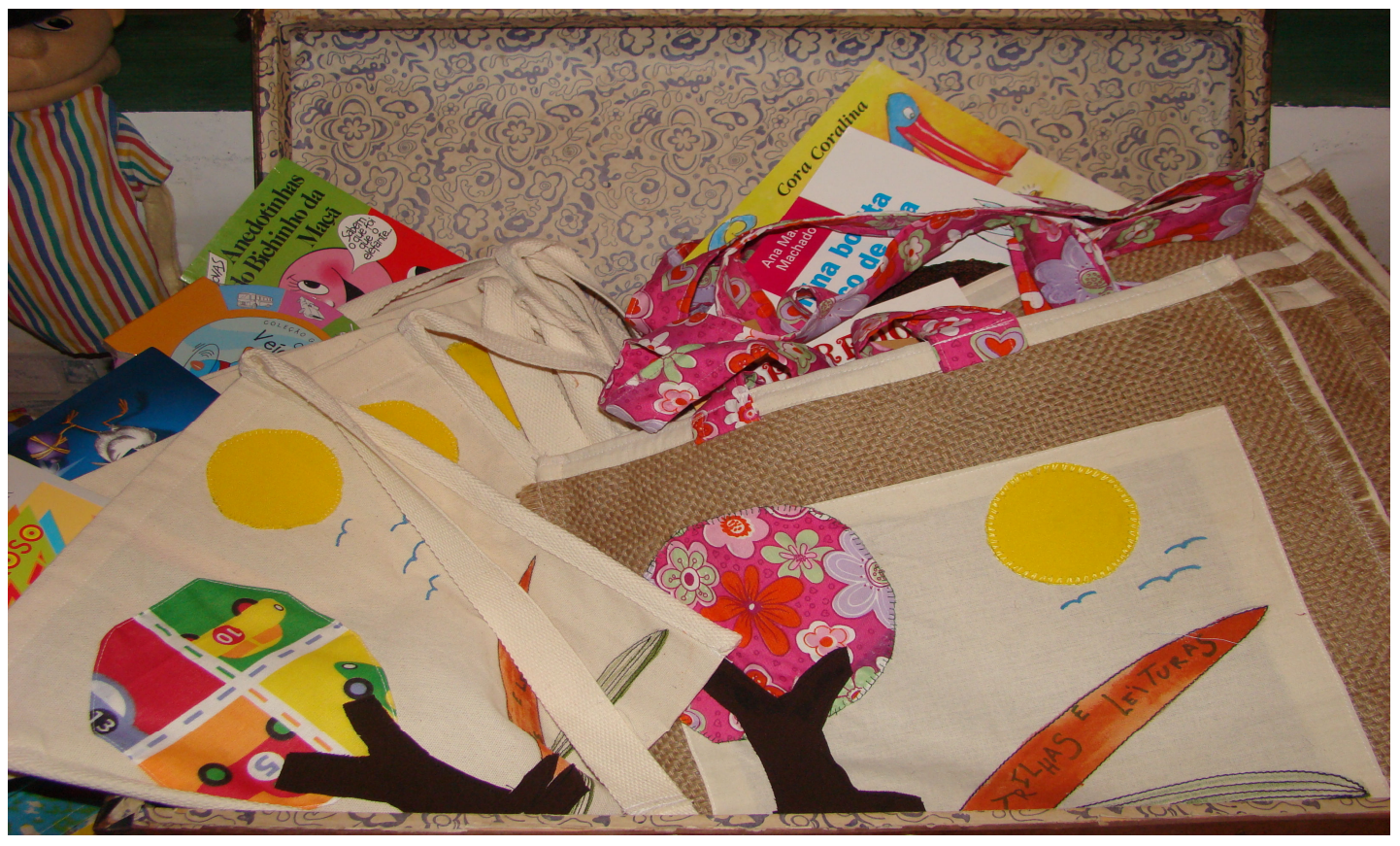

Sônia

O momento de metamorfose da mala foi tão significativo e forte quanto o do seu surgimento no abrigo. As crianças puderam perceber, com esse novo deslocamento, o quanto haviam experimentado, interagido e aprendido com a mala. Nossas viagens não se encerrariam ali. Continuaríamos por outros caminhos, viajantes sempre prontos para experimentar as aventuras à nossa espera nas mais diferentes malas onde repousam os signos.

\section{Os ambientes}

As oficinas de leitura foram desenvolvidas em diferentes espaços: no abrigo; na biblioteca pública; no carro e em outros lugares. À medida que as interações iam ocorrendo, os espaços iam se multiplicando, ganhando novos contornos e coloridos; a 
mala ia se instalando em lugares novos ou, então, deslocando usos e sentidos dados aos lugares já conhecidos onde era depositada.

Nesse processo, foi importante o papel da flexibilidade, do ajuste das atividades às condições dos grupos, numa dinâmica aberta à invenção, ao imprevisto, característica da dialogia. De algum modo, as oficinas realizavam concretamente recomendações como as seguintes:

Os espaços públicos freqüentados por crianças e adolescentes e as instâncias de formulação de políticas públicas constituem importantes instrumentos para os exercícios dos direitos de cidadania, sob a perspectiva tanto de incentivar a criatividade no campo das ciências, das artes e dos esportes, quanto na formação de lideranças infanto-juvenis. (BRASIL, 2006, p. 71)

\subsection{O Abrigo}

Situado próximo ao centro poli esportivo do município, o Abrigo "Lar Provisório", cuja mantenedora é a Prefeitura Municipal, ocupa uma área construída da seguinte maneira:

- Piso superior ${ }^{48}$ - entrada, sala de estar com sofás, televisão e DVD player, sala da assistência social, banheiro, quarto das meninas, quarto das adolescentes, cozinha, lavanderia, refeitório, quarto para bebês.

- Piso intermediário - espaço coberto (pequeno), com bebedouro. Este espaço é usado para brincadeiras e também dá acesso a um campo de futebol que pertence ao centro poli esportivo, local que a criançada usa para soltar pipa, jogar futebol e outras brincadeiras;

- Piso inferior - dois banheiros, um feminino e outro masculino; uma pequena área destinada às tarefas escolares; três quartos para os meninos e adolescentes; uma sala de TV, com almofadas e sem sofá (esta foi a sala onde aconteceu nosso primeiro encontro).

\footnotetext{
${ }^{48}$ Destinada às meninas e às adolescentes, bem como para serviços de administração, orientações particulares, organização de materiais.
} 


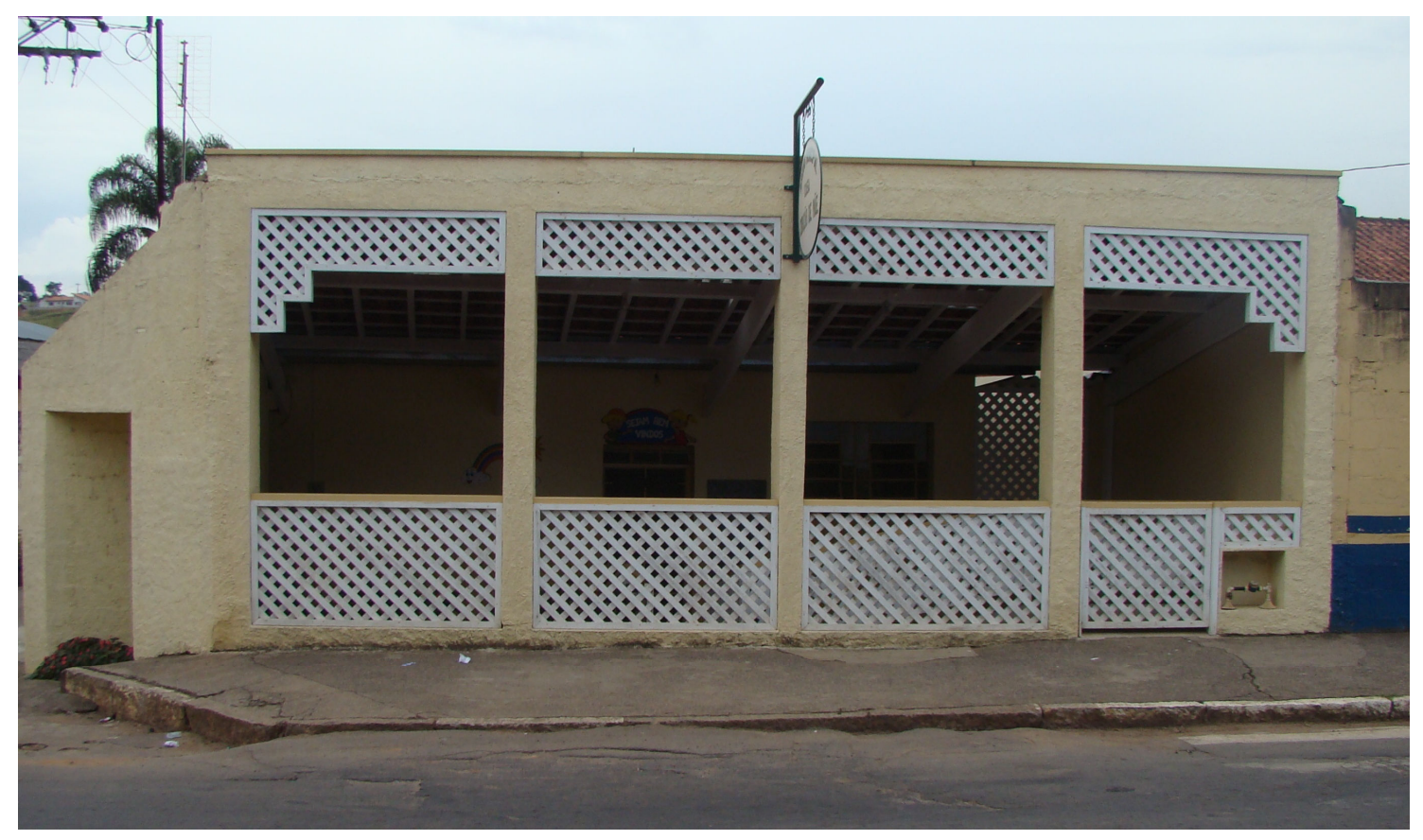

Sônia

A princípio, as oficinas de leitura começaram na sala de TV, mas também ocorreram no refeitório, nos corredores, no espaço para brincar e na sala de estar. No entanto, conforme os objetivos de personalização das mediações, a busca por espaços alternativos também ia surgindo, concomitantemente à formação das parcerias, das aproximações necessárias às atividades.

Como dissemos anteriormente, o abrigo é uma instituição que traz consigo duas polaridades paradoxais: a de ser uma instituição coletiva que atua com sujeitos em formação, com demandas de individualização particulares e que necessitam ser atendidas nos processos educativos. Há aí uma linha tênue entre o público e o privado, mas que não pode deixar de ser considerada, em seu duplo aspecto. O abrigo não é casa, mas ao mesmo tempo, é um lar - ainda que provisório, para alguns.

Essa dupla natureza reflete-se imediatamente nas ações vivenciadas nesse espaço (como veremos adiante). Vale ressaltar o conceito de instituição apresentado por Buber, conceito esse que traz tanto a questão do fora (administração, organização, lugar dos negócios...) como a do dentro (lugar das emoções: a ternura, a dor, o prazer, o ódio...). Nesse sentido, pudemos verificar essas polaridades entre o fora e o dentro acontecendo e permeando as relações no abrigo. Pudemos presenciar ali, crianças e adolescentes, assim como monitoras e demais pessoas envolvidas em situações de difícil resolução, 
uma vez que a ambiguidade característica desse lugar situado na confluência do público e do privado raramente consegue ser superada.

Pudemos observar, em decorrência das tensões geradas por tal ambiguidade, as marcas deixadas pelas crianças nos espaços. Na maioria, marcas de revoltas, como objetos quebrados, paredes riscadas, portas com maçanetas arrancadas. Por outro lado, sem dúvida nenhuma, as crianças também carregam as marcas que o abrigo vai imprimindo nelas. E estas muitas vezes, mais que físicas, são simbólicas, plenas de significados nem sempre alcançáveis pelas crianças. A diferença é que, muitas vezes, as paredes podem ser refeitas, os vidros recolocados. Quanto às crianças...

Esses espaços, conforme verificamos, podem ganhar, todavia, outros destinos, outras significações, quando ocupados por objetos e ações não usuais, que deslocam a ordem física e simbólica ali reinante. Assim, a sala de estar virou sala de jogos em uma das oficinas de leitura, instituindo uma nova e surpreendente dimensão nas relações.

Como tínhamos conversado com o Diego e com o Eduardo sobre planetas, suas formas topográficas, rios, continentes, pessoas diferentes, levamos o jogo Terra. Nesse jogo, os jogadores têm que viajar pelo Brasil, momento em que aprendem um pouco de geografia. Estava junto conosco a filha de uma das faxineiras do Abrigo. A princípio, ela ficava só olhando e não queria jogar. Então, quando já estávamos na segunda rodada, ela quis entrar, mas aí já não dava mais. Mesmo assim, ela queria dar as peças conforme o jogo ia acontecendo. Era um jeito que ela achou para participar. A transformação do espaço abriu brecha à interação não prevista, mas que acabou ocorrendo, mesmo se de modo diferenciado. A menina, mesmo se em posição auxiliar, passou a participar do jogo, ser uma das jogadoras, em interlocução com o grupo.

Ao virar sala de cinema, a sala de tv adquire também novo significado, produzindo interações e permitindo a emergência de afetos. Assim, ajudada por uma das meninas, reorganizamos a sala de $t v$, transformando-a em cineminha:

- Muito bem, vamos assistir ao filme!

As crianças aninharam-se. Apagamos as luzes e todos ficaram no maior silêncio, acompanhando o filme e sempre questionando, quando não entendiam alguma passagem. Conforme os personagens iam aparecendo, iam reconhecendo-os, relacionando-os com personagens e partes de histórias lidas, expressando-se, 
constituindo e constituindo-se no cineminha, imprimindo marcas que diferenciavam aquele espaço, normalmente utilizado para ver TV de um modo impessoal, distante e frio.

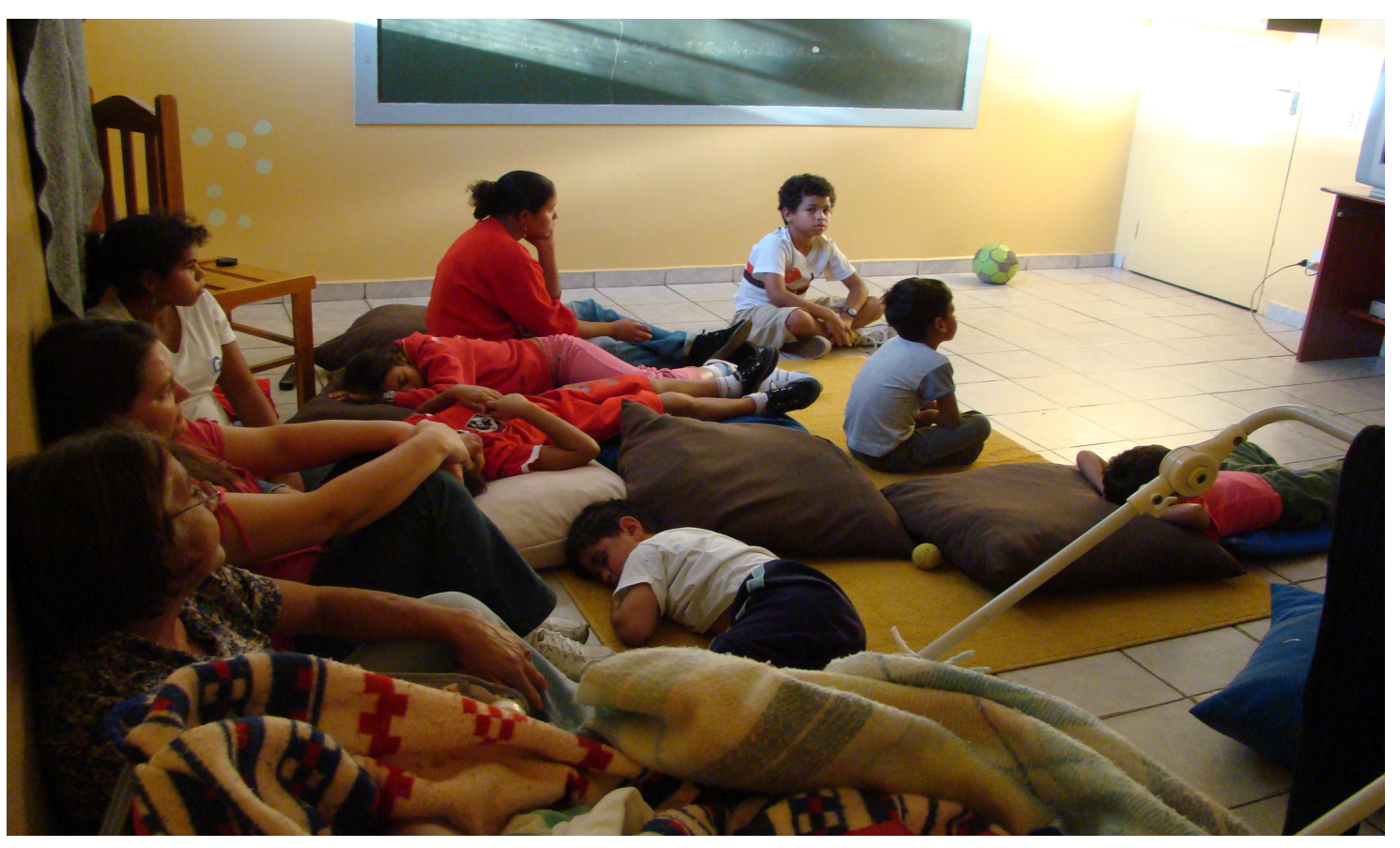

Sônia

O refeitório também virou oficina, ganhando novos sentidos: Como desejássemos trabalhar com a confecção de origamis, fizemos isso na mesa do refeitório, pois esta era a única existente e servia aos nossos propósitos. Tal fato surpreendeu algumas crianças, pois o local já estava simbolicamente marcado como refeitório. Como passar da sobrevivência do corpo para a do espírito? Por outro lado, a atividade mobilizou os brios das crianças. Elas queriam demonstrar que sabiam dobrar papel e criar formas. Dado, sobretudo que estávamos em um espaço que era compartilhado por crianças que ali lanchavam e que não participavam da oficina, mostrar estas seus saberes diferenciados de confecção de origamis era um modo de diferenciação e de afirmação identitária.

Ao se localizarem em diferentes ambientes, as oficinas de leitura vão dando oportunidade para que as crianças reconfigurem os espaços e, nesse processo, vão construindo novos contornos não apenas para os ambientes, mas para si mesmas, uma vez que passam a conviver em ambientes que são seus, ou seja, em ambientes que 
reconhecem e que são por elas reconhecidos. As histórias vão, assim, construindo histórias, num jogo entre ficção e realidade aberto à ação de sujeitos considerados em sua condição de protagonistas culturais capazes de intervir e dar significado aos espaços em que vivem.

\subsection{A Biblioteca}

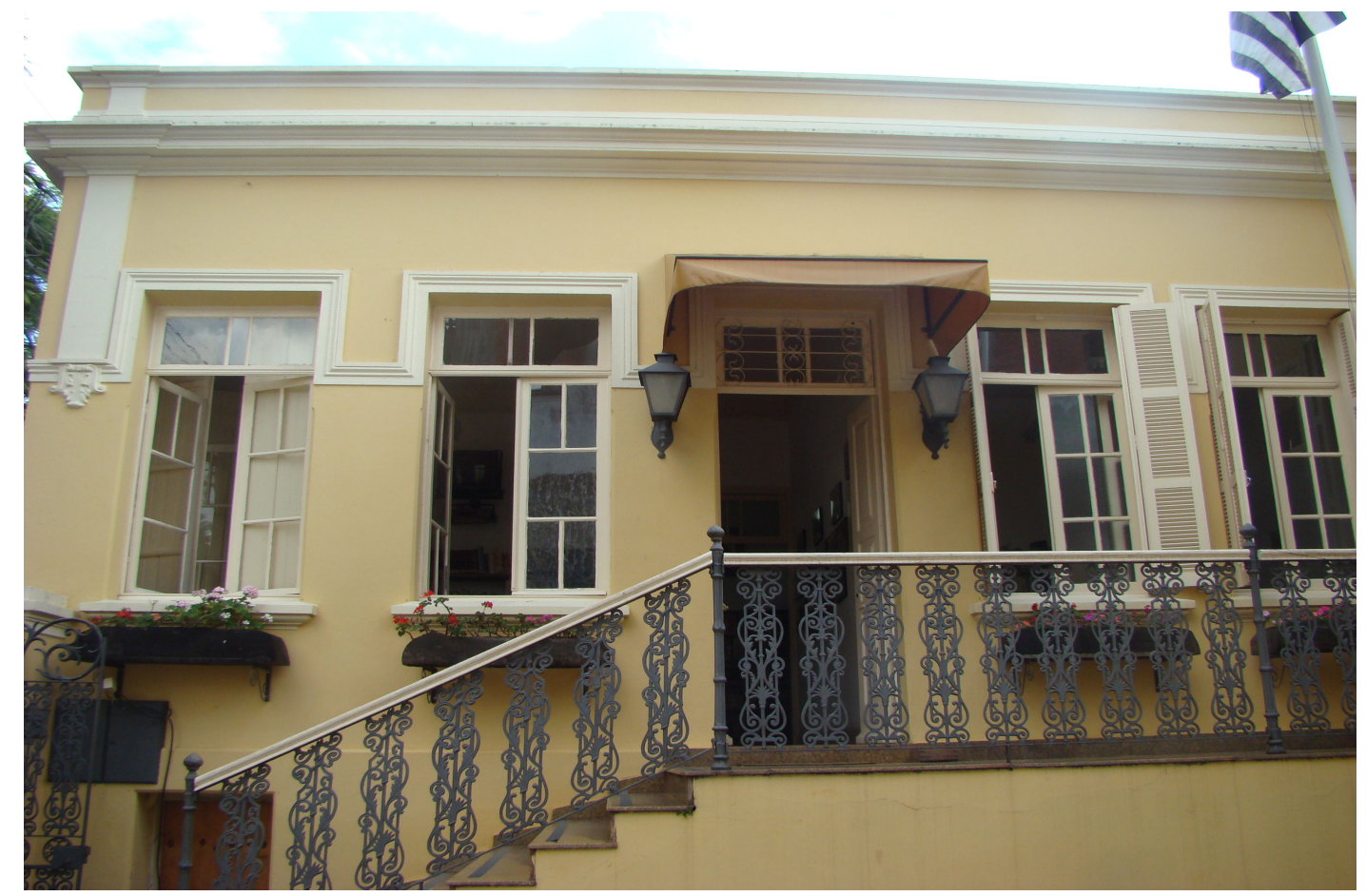

Eduardo

A Biblioteca Pública Municipal ganhou vida com a presença das crianças por lá. Primeiramente, porque tal presença era inusitada e requeria atenções diferenciadas, no sentido de suas curiosidades serem atendidas. Depois, por conta das atividades de leitura realizadas e pelo olhar interessado das crianças que pode ser verificado nas fotografias tiradas.

A Biblioteca Pública Municipal fica em frente a uma praça; possui um espaço inadequado, tanto para o acervo, como para as atividades a serem ali realizadas. São seis 
salas, uma para os livros infantis e juvenis... Não há critérios claros para a organização dos espaços. Livros didáticos se misturam aos livros de arte e de literatura em geral. Há também um rádio que permanece ligado, com volume alto, mal sintonizado, quase o tempo todo. As crianças percebem e comentam. À medida que o tempo foi passando, chegaram mesmo a manifestar desagrado.

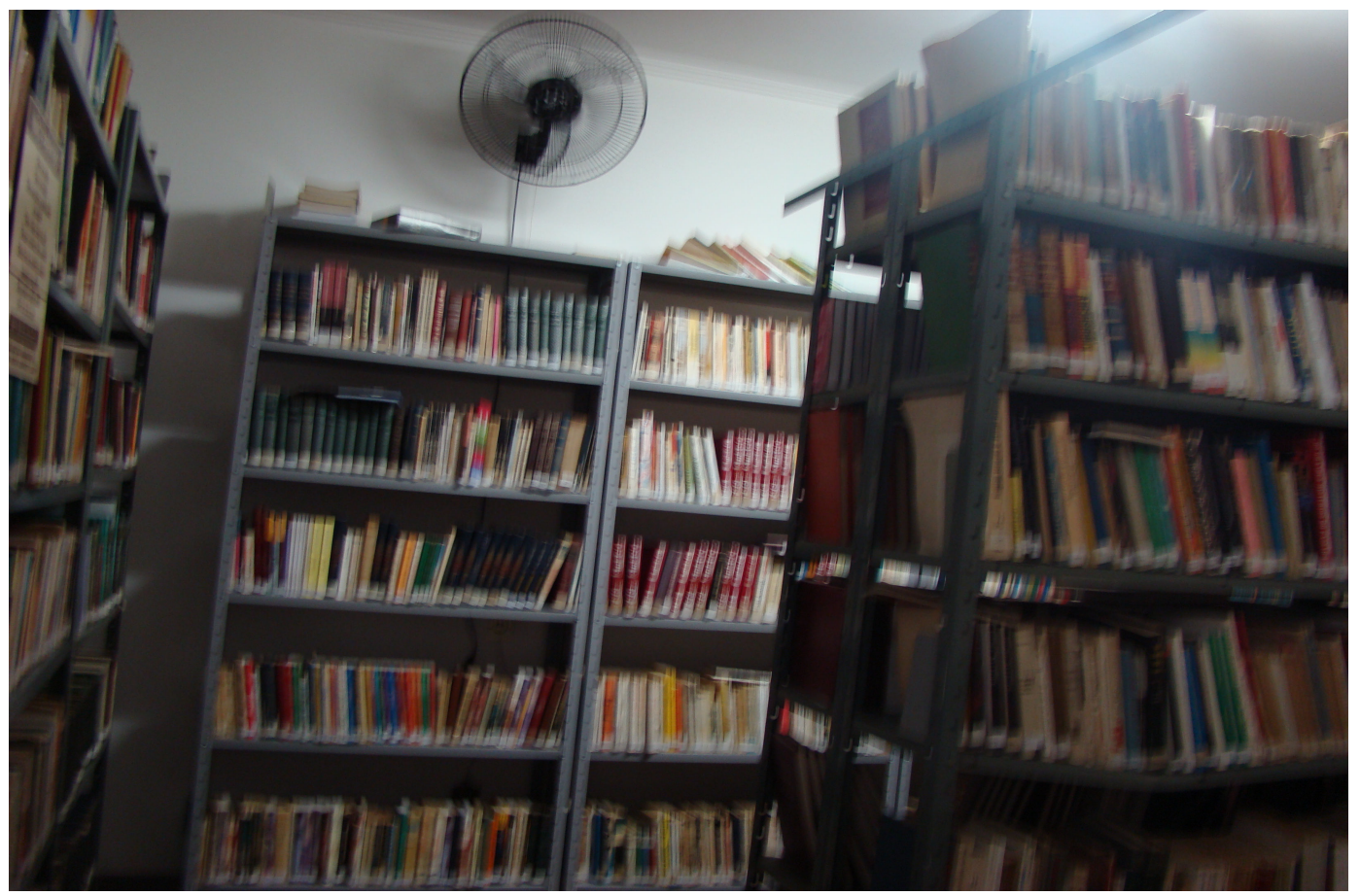

Caio

Apesar desses fatores problemáticos, ainda assim a Biblioteca acabou sendo um espaço de interesse e interação para as crianças e os adolescentes. Ali, puderam se servir à vontade dos livros. O livre acesso foi para eles um achado fantástico. Um mundo de livros a seu inteiro dispor! As crianças sabem o significado de tal fato!

- Eu posso levar?

- Pode, Rose.

- Quantos eu posso levar? 
Cada qual lê o espaço de acordo com seu repertório, suas necessidades. São percepções que se distinguem pelas vivências de cada um. Romário e Gabriel, ambos ainda não sabem ler, mas demonstram grande interesse pela Biblioteca. Especialmente em relação ao seu espaço que, por vezes, acabam usando para brincadeiras, como por exemplo, a de esconde-esconde.

A adesão das crianças e dos adolescentes ao espaço foi quase que imediata. Primeiro, deu-se pelo olhar maravilhado, diante da quantidade de livros à disposição; depois, pelo fato de se tornarem frequentadores inscritos, mediante carteirinha que lhes foi oferecida. Uma razão particular da adesão: alguns tiveram que apresentar a biblioteca a outras crianças que não a conheciam e até mesmo à nova psicóloga que estava atendendo no abrigo e que acabava de se mudar para a cidade.

Maria $^{49}$, adolescente que apesar de ter 15 anos de idade, não reconhece as letras do próprio nome, mostrava para Denise a coleção de livros da qual ela havia retirado um, de outra vez. A Sandra entra na Biblioteca de mãos dadas com o Leandro. Ele nunca estivera em uma biblioteca. Então, ela lhe apresenta o espaço e mostra onde ficam os livros infantis que ele poderia retirar e levar para ler no abrigo. Eduardo e Diego se mostram empolgados em apresentar o espaço da Biblioteca Pública à Lilian, psicóloga recém-contratada pelo abrigo. A Biblioteca Pública até então desconhecida, era deles. As intervenções realizadas permitiram que eles fossem paulatinamente apropriando-se do território, integrou-o como um valor, um bem que fazia sentido e dava uma nova dimensão às suas vidas. Uma forma de diálogo se manifestava nesse movimento e as atividades de leitura desenvolvidas permitiam o trânsito entre o fora e o dentro, de modo a permitir às crianças experiências de superação momentânea da divisão a que estão sujeitas em função da ambiguidade característica do cotidiano nos abrigos.

\subsection{0 carro}

Dada a distância da Biblioteca, o percurso do Abrigo até lá teve que ser feito de carro. Não tínhamos tempo necessário para o percurso a pé, coisa que tentamos uma única vez e que se mostrou inviável.

\footnotetext{
${ }^{49}$ Apesar de ter 15 anos de idade não reconhece as letras do próprio nome
} 
O carro passou, assim, a ser também espaço de conhecimento. Compartilhamos no caminho livros, revistas, músicas, comentários sobre pessoas que passavam:

- Esse fusca na frente, tia, é da mãe do Diego!

- Olha a casa da tia Rosa!

- Quem é a tia Rosa, Leandro?

- Ela era tia monitora, no abrigo.

- Eu não conheci. Vocês gostaram do livro que leram na biblioteca?

- Gostei!

- Eu não gostei! Essa biblioteca não tem nada que sirva pra mim.

- Será?

O retorno de carro era sempre muito animado Em um dos percursos, véspera do aniversário de um dos garotos, o Caio, que completava cinco anos, ouvimos a música Aniversário, que eles desconheciam. Logo na segunda vez que a música foi repetida, eles já conseguiam cantar.

A ida de carro era o momento para nos aquecermos para as atividades que seriam desenvolvidas na Biblioteca. A volta, o de comentarmos as experiências vividas, falarmos sobre os livros lidos, as histórias ouvidas. O carro não era só meio de locomoção que diminuía significativamente o tempo e os cuidados durante o percurso. Era espaço relacional, onde significados eram construídos, negociados, vividos; onde as relações e interações não deixavam de acontecer, mesmo quando havia um bico, uma cara fechada, um estou de mal. Tal qual o ônibus Atibaia-USP-Atibaia, o carro era tanto meio de transporte, quanto janela de acesso à rua, próxima e a paisagens sígnicas infinitas.

A fotografia abaixo revela a surpreendência dos múltiplos olhares. Foi tirada por uma menina (interna do abrigo) enquanto fazíamos o percurso até a biblioteca. Dentro do carro, ela olhava um livro de fotografias, encantando-se com a de um menino que também estava dentro de um carro, olhando para um lagarto. Para completar ela colocou meus óculos que estavam quebrados ao lado, fazendo assim a sua intervenção no olhar do fotógrafo. Ela retrata, assim, o diálogo inscrito no silêncio dos olhares. Estes podem ser entre pessoas, entre pessoas e coisas ou animais. Na multiplicidade que lhes é própria, os olhares ao se abrirem para o outro, abrem espaços novos de reconhecimento 
e pertencimento. Eu, tu e o mundo entram em relação dinâmica, aproximando-se e diferenciando-se, num diálogo de construções identitárias vivas, afirmativas e recíprocas. As trilhas para o protagonismo cultural acham-se abertas.

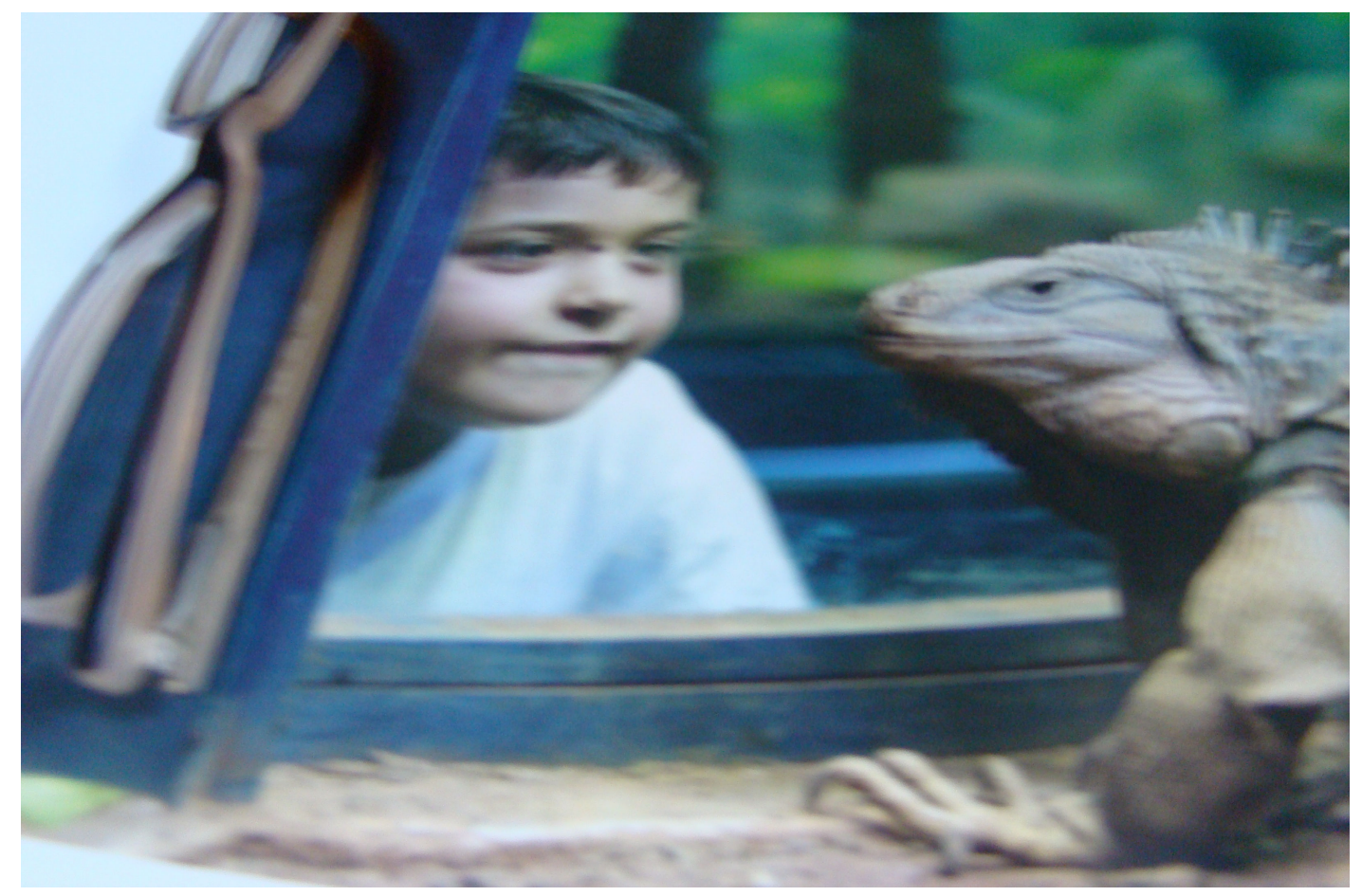

Jéssica

\subsection{Outros ambientes}

A oficina de leitura caracterizou-se por sua mobilidade, não se limitando a esse ou aquele espaço; suas mediações dialogavam com variados espaços que, articulados, configuram-se em tramas que formam as infovias do conhecimento. Quando a Biblioteca fechava, íamos para a praça em frente e podíamos ver a curiosidade alheia em relação a nós, com livros nas mãos, conversando e lendo. Ou então, antes da ida à Biblioteca, íamos à banca de jornal e revistas, apesar de já termos verificado que, assim como a Biblioteca, ela era espelho da cidade, em sua pobreza de recursos. Na Banca não havia nem quantidade notável de publicações nem diversidade. Revistas sobre cultura e artes inexistiam; as de Educação ou que tratavam de questões enfocando interesses educacionais, ficavam num canto inferior, muito atrás das demais. E surpreendente: 
também não havia revistas de esportes. O jornaleiro, por sua vez, não sabia dar explicações sobre os produtos que vendia, quando questionado.

Alguns espaços chamaram particularmente a atenção das crianças, como a Casa do Artesão. Encontraram lá objetos que os interessaram especialmente, por diferentes razões. Nesse sentido, a oficina de leitura não se ateve apenas às questões de literatura ou dos textos em geral, mas pretendeu, na medida do possível, colocar as crianças em relação com diferentes manifestações e processos culturais envolvidos nos processos de conhecimento e de construção de sentidos. Sempre que possível, buscou-se contemplar os grupos com as informações que a cidade, enquanto espaço da cidadania, dispunha.

Interessante foi a relação estabelecida com um caixa eletrônico de um banco. Fomos a um banco, com uma adolescente do abrigo. Ela tinha que sacar um dinheiro de uma bolsa que recebia do governo. Deveria, para isso, usar o caixa do banco, pegar fila, ficar esperando, porque não sabia como usar caixa eletrônico. Insisti para que a usasse, a fim de que aprendesse os procedimentos necessários para tanto. Ela aprendeu. Afinal, era preciso garantir, na prática, direitos reconhecidos pelo Plano nacional de promoção e defesa do direito da criança e adolescente à convivência familiar e comunitária:

Os espaços públicos freqüentados por crianças e adolescentes e as instâncias de formulação de políticas públicas constituem importantes instrumentos para os exercícios dos direitos de cidadania, sob a perspectiva tanto de incentivar a criatividade no campo das ciências, das artes e dos esportes, quanto na formação de lideranças infantojuvenis. (BRASIL, 2006, p. 71)

Fomos ao atelier de um artista plástico. A Tamara nunca havia estado lá e não o conhecia. Aproveitei para apresentar um outro artista plástico local, o Rafael. Ele estava pintando uma grande tela de um casal. A conversa foi boa, o Rafael falou de um quadro em que as vacas estavam nos galhos das árvores e os macacos pastavam em meio a uma neblina e também explicou o significado de outras telas. $\mathrm{O}$ artista disse que quando o abrigo mudasse para o novo local anunciado, ele presentearia as crianças com uma tela sua para ficar lá exposta.

A dimensão simbólica dos espaços públicos fala-nos dos sujeitos que aí estão ou estiveram presentes, de suas origens, do lugar que ocupam na cultura em que se inscrevem, de seus papéis, das fronteiras, das inter-relações, dos cruzamentos, das cisões - a História. Temos, assim, na leitura desses espaços pistas para compreensão 
das ações aí realizadas. Considerando o abrigo, o carro, a biblioteca, a mala e os outros lugares como dispositivos, temos, com tais categorias, instâncias por onde transitam diferentes relações, de diferentes naturezas. Uma série de ações, de cooperações e oposições, de encontros e desencontros se estabelece nos espaços, produzindo sentidos que extrapolam seus limites físicos, imprimindo-lhes marcas materiais e imateriais, físicas e simbólicas que lhes definem e redefinem permanentemente os contornos.

A cidade, como nos lembra Bosi ${ }^{50}$, é refletida em seus espaços, em suas pedras. As ações configuram o espaço e são por ele configuradas; as vivências atribuem-lhes significações e são por ele significadas. Ao forjar nossa identidade, ao nos constituirmos como cidadãos dentro dos espaços públicos nos apropriamos não só dos espaços físicos, mas de seus dispositivos, discursos, ambientes. Nesse processo, em processos dinâmicos e dialógicos, atualizamos tanto os espaços quanto a nós mesmos.

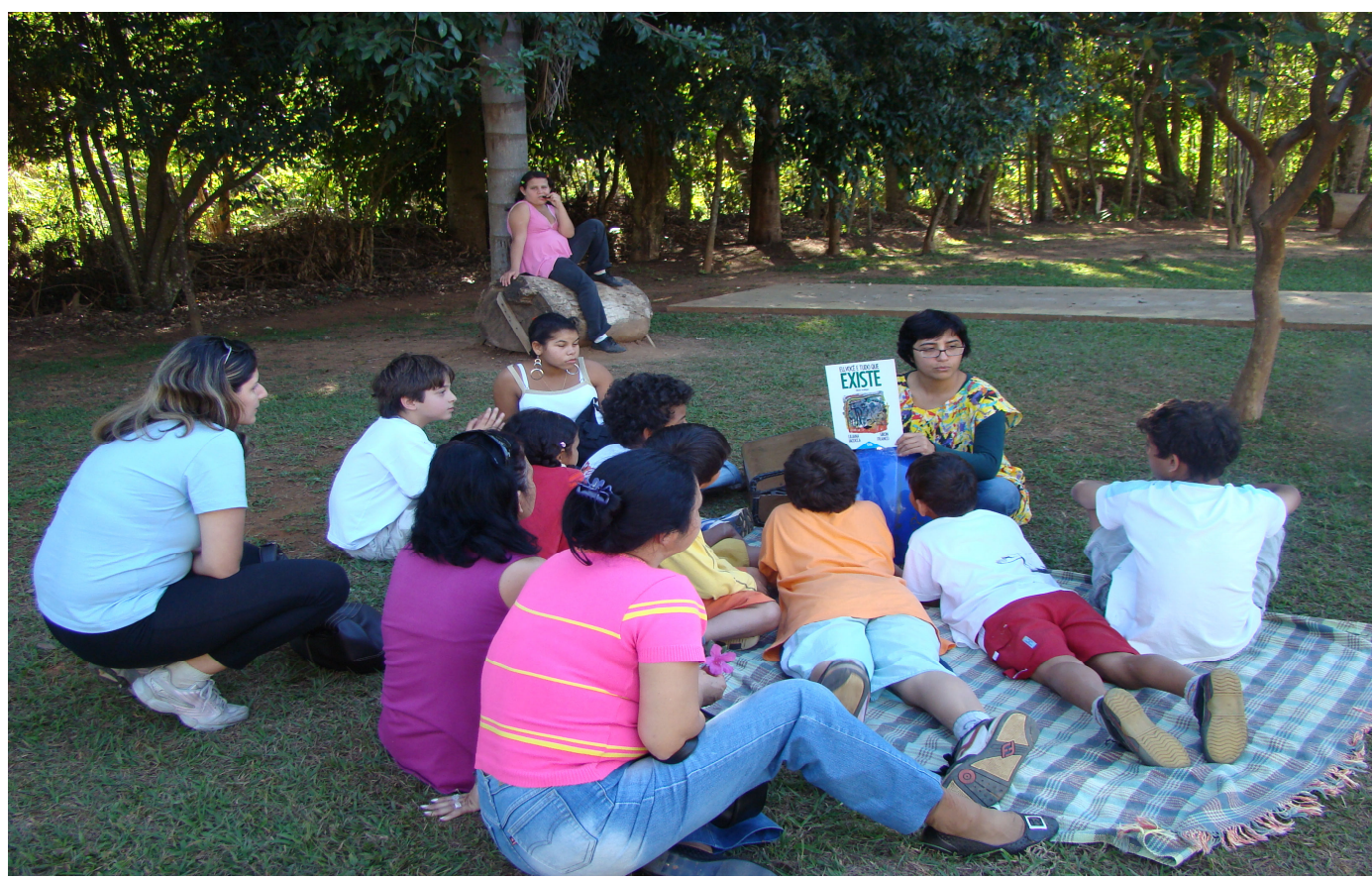

Tamara

50 BOSI, Eclea. Memória e sociedade: lembranças de velhos. 4. ed. São Paulo: companhia das letras, 1994. 


\section{As Práticas Culturais: as oficinas de leitura}

"não podemos perscrutar o mundo dos acontecimentos a partir do mundo teórico. Devemos começar com o próprio ato e não com sua transcrição teórica."

Bakhtin

Do contato com o abrigo, passando pelo primeiro encontro com as crianças e os adolescentes e pelas oficinas de leitura que se sucederam, nossas relações foram marcadas por processos permanentes de negociação, envolvendo os diferentes sujeitos em atuação na instituição. A negociação sobre se poderíamos ficar ou não para contar histórias, marcada por curiosidade e interesse misturados à desconfiança, é emblemática nesse sentido. De um lado, a mala e seus misteriosos poderes; de outro, os desejos de quem está vivo, mesclados aos receios produzidos por histórias de abandono, de desalento e de confinamento que convivem e se cruzam nos mesmos e em diferentes sujeitos:

- Fica! A gente quer ouvir histórias, sim!...

Ouvimos a afirmação como veredicto a uma proposta que acabara de ser lançada e avaliada por crianças compreendidas como interlocutores de negociações simbólicas que seriam realizadas metodicamente no Abrigo, somente, todavia, com a participação e o envolvimento afirmativo de todos em seus processos.

Tomadas, portanto, como lugar de construção identitária e cultural por meio de processos permanentes de negociação simbólica, as oficinas de leitura foram se desenvolvendo, abrindo-se para diferentes direções que dialogam entre si, como, por exemplo, as diferentes práticas, as diferentes culturas, os distintos conteúdos e os múltiplos dispositivos culturais. ${ }^{51}$ Assim, as oficinas puderam entrar em diálogo com múltiplos fazeres e expressões culturais, tornando-se elas próprias dispositivos dialógicos, abertos, portanto, às mais diferentes interlocuções.

A necessidade apresentada pelas crianças de responder a questões escolares sobre o Japão, me levou, por exemplo, a contar a lenda do Tsuru. Enquanto narrava a historia, criávamos o pássaro (tsuru) de papel com nossas mãos. Não se tratava de um simples

\footnotetext{
${ }^{51}$ Elementos descritos no quadro teórico.
} 
dobrar de papel, mas esse dobrar era recheado de significações, eu dizia às crianças que as dobras aparentemente se repetiam, mas que era uma repetição que sempre acrescentava algo mais. E assim o pássaro ia surgindo diante de nós, repleto de significações que iam sendo negociadas e apropriadas pelas crianças. A exemplo da menina personagem da história, as crianças queriam que os tsurus por elas elaborados respondessem aos seus desejos e anseios, que iam sendo expressos durante os trabalhos.

Essa oficina desencadeou a apresentação do filme $A$ viagem de Shihiro, uma animação japonesa que remete aos Mangás e aos desenhos japoneses que as crianças costumam assistir na tv. Ao verem esse filme, as crianças indagam sobre o bem e o mal e percebem nos vilões um lado bom e nos mocinhos um lado mal. Bem e mal caminham juntos no desenrolar da trama, em permanente tensão.

Como num jogo de espelhos que refletem e refratam imagens, esse filme remeteu, por sua vez, a outros filmes assistidos ali, nos quais a realidade estava sempre associada ao imaginário. Assim as historias dos filmes eram trazidas para o dia a dia das crianças e essas, por sua vez, lembravam e compartilhavam as suas memórias, levando a novas histórias como, por exemplo, a da Loura do banheiro, que tanto amedrontou um dos meninos e que, paradoxalmente, à primeira vista, por conta desse medo, resolveu ler - e ler para os irmãos - Sete historias para sacudir o esqueleto. Segundo as monitoras, ele estava tempo todo com esse livro nas mãos. Então quando chegou o dia de deixar o Abrigo, juntamente com os irmãos, escolheram levar esse livro da mala. A leitura ia atuando não apenas como forma de apropriação dos desejos, mas também como jogo simbólico que permite o enfrentamento de medos e aflições, em processos catárticos fundamentais, tal qual nos ensinaram autores dedicados à arte grega.

Em uma tarde fiquei com as crianças enquanto a monitora precisou sair para resolver algo. Ao sair ela me disse:

- Eles estão impossíveis, precisam de atividades, de brincadeiras que os entretenha e não têm.

Parecia um desafio. Eu aceitei. Perguntei a uma das adolescentes se, por acaso, não haveria algum lenço ou um pano que pudéssemos usar. Ela achou algumas toalhas 
de rosto. Então, brincamos de perder a visão. A princípio, as adolescentes que acabavam de chegar ao abrigo, não quiseram participar, mas logo entraram na brincadeira. Algumas quiseram andar sozinhas e as mãos iam experimentando as paredes, os móveis, os objetos. Emendei a essa brincadeira trechos que eu recordava do Ensaio sobre a cegueira, de José Saramago. As crianças, todas pré-adolescentes, conforme ouviam as partes da história, iam se sentando em volta de mim, com o olhar bem atento, prestando atenção. Depois, a manifestação do espanto e as perguntas:

- Meu Deus, como é possível um mundo onde somente uma pessoa veja?!...

- É de verdade?

A partir daí, pudemos discutir o sentido das visões plurais, abertas e o das visões únicas, fechadas; o mundo controlado por um único olhar e o mundo livre e infinito dos múltiplos olhares.

Aproveitando, portanto, de uma situação dada, entramos - e aceitamos - no agito das crianças, sem, contudo, abandonar nossas propostas que acabaram produzindo tanto um deslocamento relacional como simbólico. A negociação considerou, assim, tanto necessidades vontades e intenções das crianças, como do mediador. Daí talvez a razão principal da aceitação pelo grupo da proposta de leitura lançada. Ao pedir que colocassem uma venda nos olhos, acolhíamos o desejo de brincar das crianças, a necessidade de gasto de energia física. Só cortamos o jogo quando a brincadeira começa a se oferecer como um risco, pois algumas crianças começam a se aproveitar da situação para machucar o outro. Foi nesse momento que entrou a narração dos trechos da história de Saramago, sobre uma cidade onde todos perdem a visão. Ao se espantarem e indagarem se isso seria possível, as crianças vão retirando as vendas dos olhos, vão se sentando junto ao mediador, ávidas para ouvir a historia. Dá-se início a outra espécie de jogo simbólico, momento em que as histórias assumem a função lúdica que, segundo Barthes, lhes é própria: a literatura é festa, ensinou-nos o autor da Aula ${ }^{52}$.

Esses desdobramentos das atividades conferindo deslocamento de sentidos dos espaços e dos tempos de cada um se dava por meio de negociações, ou seja, pelo exercício constante da dialogia. Nesse sentido, se as oficinas de leitura ocorriam no

\footnotetext{
${ }^{52}$ BARTHES, Roland. Aula. São Paulo: Cultrix, 1988.
} 
abrigo tanto com uma criança apenas, como em duplas, trios ou com o grupo todo de uma vez, sua definição ia se dando a partir das negociações, das demandas e das dinâmicas institucionais. No caso relatado acima, não sabíamos previamente da solicitação feita. Na verdade, estávamos programando para aquele dia uma oficina mais individualizada, com parceiros definidos e não com o grupo todo. Tivemos, no entanto, que flexibilizar nossa proposta, a fim de atender a uma demanda ocasional. O que não mudava, contudo, eram os propósitos que nos norteavam: permitir a descoberta da leitura pela comunidade do abrigo, tomada como possibilidade de vivências ricas e concretas, esperança aberta e ao alcance das crianças e jovens ali alojadas, desde que praticada como forma de diálogo consigo mesmo e com o mundo.

Sendo assim, as oficinas eram momentos propícios para fazer os repertórios dos sujeitos interagirem, seja em grupos, em parcerias ${ }^{53}$ ou entre parceiros e o grupo todo. Os exemplos abaixo procuram dar a medida de tais práticas:

\section{a) Oficinas em grupo:}

Auxiliada por uma das meninas organizamos a sala para o filme Os irmãos Grimm:

- Muito bem, vamos assistir ao filme!

Uma das crianças (havia três e duas adolescentes) me disse que não assistiria àquele filme porque dava medo só de ver a capa do DVD. E saiu. As adolescentes assistiram somente a um pedaço e depois foram ao dentista. Então, ficamos eu, um garoto de nove anos e um outro de cinco que, depois de tumultuar bastante o ambiente, passou a prestar atenção na história. À tarde, colocaríamos novamente o filme para outro grupo de crianças. Será que se interessarão? São quatorze, no total, e não apenas cinco como de manhã. Antes de iniciar, todavia, falamos um pouco sobre a história. Lembrei da importância desses irmãos. Não fossem as anotações das histórias que fizeram, hoje talvez não tivéssemos a maioria das histórias infantis. Disse-lhes que iriam perceber durante o desenrolar do filme a entrada de personagens que eles já conheciam de livros que havíamos lido.

\footnotetext{
${ }^{53}$ Por parcerias entendemos aqui duplas formadas com a pesquisadora ou entre as crianças
} 
Aninharam-se, apagamos as luzes e todos ficaram no maior silêncio acompanhando o filme e sempre questionando quando não entendiam alguma passagem. Alguns deles (três) iam reconhecendo, conforme ia aparecendo, os personagens e partes de histórias: Chapeuzinho Vermelho, João e o pé de feijão, Branca de Neve, João e Maria, Rapunzel, a Bela Adormecida, dentre outras. Em alguns momentos uma menina fazia xiuu, pedindo silêncio. Após o filme, aproveitamos para falar dos medos que todos temos e um deles disse:

-O que mais dá medo mesmo é a Loura do Banheiro!!!

E contou essa história para nós.

\section{b) Oficinas em parceria:}

A Tamara contou um pouco da sua história e como havia parado em abrigo. Semelhante a tantas outras crianças... E como tantas outras aguarda por uma solução judicial. Emprestei-lhe o livro Porque não dancei.

Aproveitamos pra conversar sobre a formação das pessoas, ela conta a história de uma amiga que, apesar de ter 15 anos, já estava esperando o segundo filho e tinha problemas de convivência com a mãe. Perguntei-lhe se havia mais amigas ou mais alguém em sua turma que lia Shakespeare.A resposta foi não. Disse-lhe que tanto a vida dela, a trajetória, o fato de com treze anos ter que procurar pela Assistente Social da cidade, porque não tinha um lugar pra dormir, já dava a ela uma distância em relação às outras pessoas, demonstrava que ela tinha uma esperteza, que sabia se virar, mesmo em meio à dor. Então, disse-lhe que tanto tais experiência, como o fato de ler, fazer teatro e outras coisas mais, faz dela uma pessoa diferente, aguçava-lhe os sentidos.

- Aguçar? O que é aguçar?

Então, temos mais assunto para nossa conversa. Em meio a conversa é mostrado o livro de fotografias do Sebastião Salgado. Uma monitora que estava por perto também quis ver. E pudemos desfrutar e nos aproximar cada vez mais olhando as belas imagens do livro escolhido.

\section{c) Oficinas entre parceiros e o grupo todo}


Essa modalidade de organização das relações foi observada quando o grupo se reuniu para escolher as fotos que comporiam o vídeo sobre o percurso do abrigo a biblioteca, descrita a baixo. Às crianças e aos adolescentes foi sugerido que tirassem fotos do caminho que os levava à Biblioteca Pública, a fim de que fizéssemos uma exposição das mesmas. Porém, como teríamos que investir uma pequena verba que não tínhamos, a montagem de um vídeo surgiu como uma resposta.

Os percursos foram realizados em duplas. Explicamos como funcionava a câmera digital, inclusive o zoom, recurso importante pra trazer o que está longe para perto do olhar; explicávamos o contrario, ou seja, que, além de prestar atenção ao caminho, eles teriam que olhar para alem desse. Cada criança poderia tirar sete fotos alternadas com seu parceiro, assim todos teriam a oportunidade de retratar todo o percurso. Como o percurso incluía a volta, eles poderiam reservar fotos para serem retiradas na volta. Evidentemente, o numero de fotos excederam ao combinado.

O momento da escolha das fotos representou uma interação como ainda não havíamos observado: os parceiros se reuniam, trabalhavam e olhavam juntos o que os outros parceiros estavam fazendo. Então, a partir do olhar compartilhado dos parceiros, tivemos uma série de discussões sobre aquele percurso que derivaram em escolhas, objeções, concordâncias/discordâncias, enfim, uma serie de negociações de valores simbólicos.

As oficinas permitem que observemos as negociações e apropriações que as crianças e os adolescentes vão fazendo. Elas se revelam pelos discursos, mas também em suas expressões faciais, falas, comportamentos e atitudes. Assim, as historias dos atores dessas oficinas de leitura vão se misturando e compondo outras histórias, misturadas, por sua vez, às histórias escritas ou apenas narradas:

- Olha, só! Ciranda de pedra!

Imediatamente Jéssica indaga ao mediador que tirava o livro da estante:

- Onde tia? Esse livro é o da novela que tá passando?

- Não sei, acho que sim.

- Ah, eu posso levar esse livro, Tia? 
Observamos aqui o interesse da Jéssica por um livro cujo titulo chama a atenção por ser o mesmo da novela que ela está acompanhando na tv. Após emprestar o livro, ela o lê rapidamente para antecipar-se aos capítulos televisivos. Assim, ela se coloca adiante dos outros que só vêem a novela pela tv. Por outro lado, verifica que a adaptação televisiva não estava sendo fiel ao livro. A identidade vai, assim, se constituindo, ao mesmo tempo em que os juízos e valores culturais vão sendo apropriados, numa dinâmica rica e complexa que envolve a afirmação de sujeitos culturais e, ao mesmo tempo, da própria cultura.

Certo dia, ao sairmos da Biblioteca Pública, eu falava com uma funcionária sobre um livro que terminara de ler - O poema pedagógico, do Makarenko. Não percebi que a Tamara estava atenta ao que eu dizia. Então, quando estávamos nos dirigindo ao carro, ela diz:

- Nossa, Sônia, esse livro parece ser bem legal para eu ler. E me faz lembrar o livro Capitães de areia, do Jorge Amado.

Não contive o meu espanto e disse:

- Nossa, Tamara!

- Que que foi tia? Falei alguma bobagem!?

- Não, desculpa! É que antes de começar a ler o livro do Makarenko, eu fiz uma pesquisa na internet, pra saber mais sobre ele. E li um artigo de um juiz da vara da infância. Ele comentava justamente a semelhança entre a situação de abrigo, $O$ poema pedagógico, e Os capitães de areia, do Jorge Amado. Percebe? Você está fazendo a mesma relação que o juiz fez no artigo dele!

- Nossa! Que legal!

- Muito! Demais!

A surpresa agora era nossa! Da mediadora/pesquisadora e da Tamara. Dois livros diferentes, que encontram pontos comuns em um artigo de um juiz, na fala de uma adolescente, mediada pela pesquisadora e suas preocupações acadêmicas. Quantos fios, quantas tramas, quanta complexidade nos processos de constituição simbólica. A dialogia permitia, contudo, as sinapses, o encontro, a presentidade, ou seja, a convergência de saberes díspares na construção de novos saberes, em movimento 
permanente de construção e reconstrução em relação com o outro presente ou mediado por textos ou outras modalidades culturais.

A Tamara faz teatro e pensa em retirar livros de poesias ou de romances, como por exemplo, Romeu e Julieta, de Shakespeare. Achamos vários livros do autor, mas a Tamara não queria em forma de peça teatral. Mas acabou ficando com o livro de capa dura, vermelho e grosso, com três peças de Shakespeare.

- Como vou ler isso?!.

- Bom, então vamos procurar umas adaptações.

E encontramos vários títulos de Shakespeare, adaptados em publicações de literatura juvenil. Então lhe falei das muitas versões do grande criador inglês, tantas quantas pude. Entre uma procura e outra, perguntei-lhe a respeito de um personagem da célebre tragédia, Sansão:

- Que Sansão é esse aqui, Tamara, do Shakespeare, ou seu? Pense, ele não descreve nada, você tem que imaginar, se ele tem barba, ou não; se ele é forte, negro, loiro... Ela me responde:

-É meu!? ... Nossa! Bom ,então vou levar esse!

Mais adiante ,Tamara comenta a dificuldade em ler o livro de Shakespeare.

- Para entender alguns autores, às vezes, é preciso alimentar o que já se sabe, criar conexões entre leituras.

Ela responde:

- É, mas isso tem que ser aos poucos.

-Exatamente, tem que ser aos poucos... e sempre.

Assim, encontramos também em relação à interação vivida entre autor, texto, leitor a questão da presentidade e da não-finalização aí implicadas. Os diálogos se abrem em propostas, em caminhos que dependem de tempo para ser percorrido e, como 
disse a própria Tamara, corroborando com o dizer de Bachelard ${ }^{54}$, tem que ser aos poucos.

Mas que tempo é esse? O tempo de um sujeito pode não ser o mesmo tempo do outro e, muito menos, o das instituições por onde cada um transita. E mesmo cada indivíduo terá diversos tempos, prazos nos quais se forma e se constrói como ser 1 individual e cultural.

\section{O tempo}

As possibilidades da vida são as possibilidades do tempo. As ações transcorrem dentro de seus limites. Ao descobrir sua finitude enquanto ser biológico, o ser humano inventa-se e reinventa-se, transformando matérias em maneiras de ter domínio do tempo e de suas variantes.

Se os acontecimentos se sucedem (cronos) ${ }^{55}$, é nas tramas da memória, das emoções, dos sentimentos, dos pensamentos, dos movimentos que ele ganha corpo, significações e razões de ser (kairós) ${ }^{56}$. Vivemos e nos constituímos nessa dialética, transitamos por ela quando nos colocamos em diálogo com o mundo. O tempo ganha, assim, outras dimensões que nos extrapolam, sem, contudo perder essas duas forças de naturezas distintas, uma linear, outra reticular.

O ser em dialogo percebe, assim, instâncias temporais em si, no outro e em objetos, instaurando a não-finalizabilidade preconizada por Bakhtin e a presentidade por Buber. Dessa maneira, encontramos as crianças e adolescentes vivendo no abrigo diferentes temporalidades, sem que, necessariamente estas se harmonizem, já que, em geral, os ritmos institucionais são distintos e tendem a se sobrepor aos das crianças, consideradas individualmente e em suas subjetividades singulares. Não só o coletivo tende a se impor como padrão em todas as situações, como cronos tende a se sobrepor a kairós.

\footnotetext{
54 “ “...] Para que cada ser cresça e produza, é preciso o tempo certo, um prazo concreto, seu prazo individual. [...]" (BACHELARD, 1996, p. 62).

55 “[...] Relaciona-se ao aspecto quantitativo do tempo, ao tempo disciplinador, organizador, coletivo, que rege a vida. [...]" (OBERG, 2008, p.19).

56 “"...] está ligado à idéia de tempo qualitativo, subjetivo, indivisível, experimentado, vivido, individual e a uma concepção temporal cíclica (o tempo da natureza, das estações do ano repetindo-se por gerações, sem acumulo, sem historia)." (OBERG, 2008, p. 19-20).
} 


\subsection{Tempo Institucional}

Nos abrigos, o tempo institucional é regido basicamente por um cronos, indiferente aos outros tempos necessários ao crescimento e ao amadurecimento das crianças. Como salienta Oberg, cronos organiza e rege a vida, enquadra os seres humanos segundo uma faixa etária, dentro de períodos no dia, na semana, no mês e no ano. Formam-se, então os coletivos impessoais, as comunidades sem sujeitos singulares que vivem e partilham momentos em ações comuns.

Ora o tempo das oficinas de leitura seria também definido por tal predominância, na medida em que as oficinas se inseriam dentre as diversas atividades e programações do abrigo, tendo, portanto, que se adequar às grades horárias fixas e dadas. Da mesma forma, quando íamos á Biblioteca, devíamos nos adaptar à ordem temporal instituída. Sentíamos, por exemplo, que estava na hora de nos retirar do espaço da Biblioteca Pública quando o atendente começava a fechar as janelas e as portas. Algumas vezes, também, tivemos que renunciar à ida à biblioteca porque nos faltaria tempo para tal. Da mesma forma, ouvimos reclamações em relação à duração dos filmes que estávamos passando e que, apesar do interesse das crianças, reclamava-se que a exibição avançava sobre o horário do lanche.

Além desses exemplos, outros episódios indicavam a prevalência do tempo institucional sobre outras temporalidades, como a impossibilidade, por razões organizacionais, de reunirmos em atividades comuns, ao mesmo tempo, todas as crianças e adolescentes do abrigo. Também a concorrência e a inflexibilidade das atividades programadas reforçam o predomínio de cronos.

Assim, ao encontrarmos as crianças assistindo a um desenho, empinando pipa ou fazendo qualquer outra atividade, pensamos nessa concorrência e de que maneira poderíamos negociar com ela, de modo a trabalhar em favor do desenvolvimento dos repertórios de cada um, considerando suas singularidades e demandas específicas. Descobrindo e reconhecendo esse universo onde atuamos, podemos constituir modelos representativos e identitários.

Desse modo, pudemos observar que a concorrência entre as atividades poderá ser uma via de aproximação, mas que os resultados obtidos dependerão de uma espera, de um tempo e de um reconhecimento que não é, em geral, imediato. O caso do Felipe em relação ao futebol serve de exemplo. Ele sabia que deixava de ir ao futebol nas quartas- 
feiras porque nesses dias participaria das oficinas de leitura. Por esse motivo, se rebelou e, uma vez que não podia chutar a bola, chutava o que encontrava pela frente, inclusive nosso carro.

O caso foi observado e analisado. Houve um reconhecimento de que o futebol era mais interessante para ele. Sendo assim, não fazia sentido obrigá-lo a continuar nas oficinas. Porém, quando do encerramento das nossas atividades de pesquisa no abrigo, Felipe foi lembrado e, chamado, participou de todos os momentos em que nos reunimos em grupo, avaliando nossos trabalhos, produzindo um vídeo. Foi ele o único menino que pediu para colocar uma frase no vídeo: Não precisa de gaiola. Passarinho tem que ser livre.

O tempo das descobertas não é homogêneo e não prescinde da espera. Foi esta uma de nossas descobertas com as oficinas. Como o mediador se multiplicará e dará atenção igual a todas e ao mesmo tempo, eis questão extremamente difícil de ser respondida e administrada? Muitas vezes, compra-se diante das necessidades impostas pelas dinâmicas coletivas, um mal querer, um bico, dada a impossibilidade de se dividir a atenção para todas as demandas.

Enfim, ao nos depararmos com a prevalência do tempo institucional sobre as demais temporalidades, fomos levados a incorporar outras temporalidades às nossas oficinas, buscando que estas fossem tratadas como categorias essenciais e intrínsecas aos processos de construção de significados. Tratamos, assim, de negociar o tempo institucional com o tempo pessoal, as exigências da rotina institucional com os momentos demandados pela leitura, a prosa, o narrar da vida que ia acontecendo nas oficinas, permitindo que o universo da escrita encontre porto no olhar do leitor, no seu falar, na troca de informações e na negociação de sentidos promovidos pelo diálogo.

\subsection{Tempo Pessoal}

O tempo vivido traz a surpreendência ao campo das ações. O deus kairós entra em cena trazendo a qualidade, a subjetividade, a contemplação, a reflexão, a saudade, a memória, o desejo e uma série de outras ações forjadas no interior de cada indivíduo, de acordo com seus repertórios, contextos socioculturais, suas marcas do viver. Trata-se 
do tempo vivido, experenciado, histórico de cada um, aliando-se ao tempo biológico e social, configurando e sendo configurado, tecendo e sendo tecido pelo tempo das interações, por meio de diálogos múltiplos.

Mas de que maneira o tempo pessoal respondeu, ou melhor, se tornou uma forma de articulação com o tempo institucional? De que maneira as condições necessárias à tal incorporação da temporalidade pessoal foram se tornando possível? De diferentes modos, do quais destacamos dois:

a) pela flexibilização do tempo, quando a ação focou-se em um numero menor de crianças.

b) pelo desenvolvimento de atividades em duplas, o que permitiu a formação de parcerias entre as crianças, ou seja, o desenvolvimento de interlocuções entre parceiros de leitura. Pelo diálogo, tais parceiros se alimentavam, apoiavam, trocavam, vinculavam, a partir de diferentes dimensões psicológicas, sociológicas e mesmo biológicas, já que a razão etária contava bastante na formação das parcerias, assim como as de gênero.

Se o tempo é imperativo, são os atores que o encarnam em suas atitudes, suas falas, gestos, opções. São eles que operam as categorias e definem as dimensões e o lugar social dos tempos pessoais e dos tempos institucionais.

\section{Os protagonistas}

\subsection{As crianças e os adolescentes}

O número de internos ${ }^{57}$ nos abrigos costuma ser flutuante e depende de algumas variáveis que, na maioria das vezes, estão relacionadas às decisões do poder judiciário. Por esse motivo, não se sabe, ao certo, por quanto tempo as crianças e adolescentes estarão sob a custodia do Estado. Como as demais atividades educativas e culturais, as oficinas de leitura desenvolvidas no Abrigo Lar Provisório podiam ter caráter mais pontual para algumas crianças e mais permanentes para outras. Era preciso, em tais

\footnotetext{
${ }^{57}$ Por um período de um ano, a pesquisa envolveu: cinco crianças, sete pré-adolescentes, cinco adolescentes.
} 
circunstâncias, considerar especialmente os momentos particulares, pois, muitas vezes, as oficinas eram ocasiões de compartilhar sentimentos, sensações que poderiam estar ou não imediatamente associadas às leituras.

Ser interno em um abrigo já traz implícita uma militância. São esses atores em suas relações que conferem ao abrigo - instituição pública - a dimensão do íntimo, do pessoal, do dentro (BUBER, 1979), como o lugar onde desenvolvem suas emoções e deixam ai suas marcas.

Apesar do quadro, sem nenhuma dúvida crítico da vida em Abrigo, ações afirmativas das crianças se manifestam de diversas maneiras, no dia a dia, tal como nos mostrou Esmeralda Ortiz ${ }^{58}$, a menina de rua hoje jornalista. Pode ocorrer, como pudemos verificar, do adolescente procurar, por si só, a assistência social do município por não ter onde ficar, ou passar a noite; algumas mostram ter consciência do Estatuto da Criança e do Adolescente, sabem que o estatuto diz que criança não trabalha e contestam o pai que quer obrigar o filho a trabalhar, a violência, tanto em casa como no abrigo:

- O juiz me disse que você, nem ninguém, pode me bater.

- Eu li, tava escrito lá, que o juiz disse pra gente voltar pra casa, que a gente não precisa mais ficar aqui!!

O gesto afirmativo do leitor pode ser expresso apenas por um olhar ou uma expressão facial diante de uma leitura. Antes de entregar Retratos de crianças do êxodo, do Sebastião Salgado, às crianças, explicamos o que era êxodo, o que as crianças retratadas representavam ali, que a maioria delas já não possuía família. $O$ silêncio imperou diante das fotografias. Muita concentração e apenas algumas observações foi o que se seguiu. Palavras esparsas sobre as marcas nos corpos, os olhares, que pareciam saltar da fotografia.

Em outros momentos, a ação afirmativa vem expressa pelo esforço em vencer a timidez do falar:

\footnotetext{
58 ORTIZ, Esmeralda do Carmo. Por que não dancei. São Paulo: Atica, 2001.
} 
- Então, quando chegar à Biblioteca, vocês vão perguntar ao Seu Dito se ele tem gazeta velha para fazer barquinhos?

- Ai, eu não, pergunta você, Tia.

- Ué, vocês não querem fazer os barquinhos? Então, tem que perguntar!

E, depois de muita negociação, o Rafael diz:

- Eu vou perguntar!

O diálogo permite, pois, que essas ações afirmativas ganhem corpo (in-corporem) e reconheçam o direito ao exercício da palavra. A voz do leitor e ele próprio são protagonistas dos atos simbólicos dos quais participa. Compreender, as crianças e os adolescentes do abrigo como protagonistas culturais das oficinas de leitura foi, a nosso ver, determinante para que o ato de ler, ali vivenciado como experiência significativa e desejado, indicasse possibilidades de apropriação de si e do mundo.

Nesse sentido, os diferentes atores do abrigo desempenham um papel fundamental para que o protagonismo infantil seja reconhecido.

\subsection{Os mediadores}

\subsubsection{A Assistente Social, as psicólogas e as monitoras do Abrigo}

A Assistente social do Abrigo "Lar Provisório" é uma pessoa jovem, recémformada pela UNESP. Trata-se de profissional atenta às necessidades das crianças e dos adolescentes. Além do contato direto com estas, faz também a mediação entre o abrigo e outras instituições, como o poder judiciário, o conselho tutelar, as famílias, a comunidade, a escolas. Por outro lado, é profissional que procura manter-se informada e atualizada sobre sua área, cursa a especialização $O$ ser social no campo sóciojurídico, Considera que assim, relacionando teoria e prática, o trabalho com as crianças é beneficiado. Enfim, temos na gestão do abrigo uma profissional sensível e competente, envolvida com as crianças e sua problemática. Ao abrir as portas da instituição para as oficinas de leitura, mostrou-se interessada em colaborar para o avanço do atendimento e das condições de vida das crianças e dos adolescentes. 
As psicólogas foram as primeiras a se posicionarem a favor das oficinas quando da reunião com a assistente social do município, e também foram às pessoas que me recepcionaram no abrigo naquele dia de chuva e colaboraram na negociação com as crianças. No momento de minha chegada com a mala, quando as crianças ainda não tinham sido instigadas a ver o conteúdo da mesma e diziam que eu podia ir embora, a psicóloga que estava com o grupo disse:

- Puxa vida, é assim que vocês tratam visitas!?

A partir de tal intervenção, as atitudes começam a mudar, no sentido já relatado.

Quando do começo desse estudo, havia duas psicólogas que se reuniam com as crianças e adolescentes uma vez por semana. Foi em uma dessas reuniões que se deu o nosso primeiro contato com as crianças. Posteriormente, foi contratada, através de concurso público, uma psicóloga que passou a integrar o quadro de funcionários do abrigo. Essa ultima fazia reuniões com as meninas, com os meninos, os chamados Momento do Grupo.

Oportunamente, participamos de uma dessas reuniões. Antes, porém, de me convidar, perguntou aos meninos se eu poderia participar. Eles responderam que sim. Observamos algumas dificuldades nessas reuniões, principalmente em relação à observação dos horários, já que as questões eram, a todo momento, desfocadas, em virtude de as crianças requerem tratamento especial, chamando frequentemente ao mesmo tempo a atenção de uma única pessoa e, não conseguindo isso, tentam de todas as maneiras chamar a atenção para si, no desejo de serem diferenciadas. Os momentos grupais para muitos eram vividos como momentos de indiferenciação e, dada a problemática de vida das crianças, elas precisavam ser reconhecidas, acolhidas nas diferenças. Enfim, se o protagonista, no sentido grego, encarna os ideais da coletividade, é, também, um ser diferenciado e nisto consiste sua excepcionalidade de ser único, de ser um e, ao mesmo tempo, todos.

As monitoras são as pessoas que estão diretamente envolvidas com as crianças e com os adolescentes. No dizer da Assistente Social:

- Elas são as cuidadoras. 
E os cuidados são muitos e multiplicados pelo número de internos. Esses cuidados vão desde o banho, fazer lição, ensinar a se comportar, passando pela ida ao médico e a outros lugares, dentre outras ações.

Encontramos nas monitoras a colaboração necessária para as oficinas de leitura, além da própria participação delas. Destacamos aqui a Zulmira.

A Zulmira é uma monitora que cativa ao primeiro olhar e também pelo nome que nos remete a canção de Jobim:

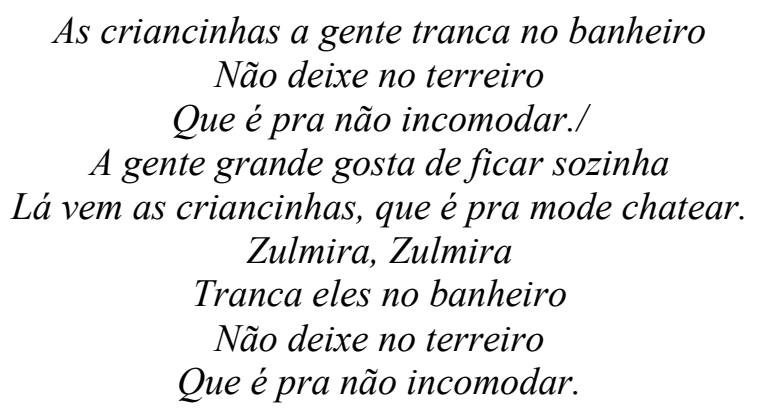

Um dia, encontramos a Jane (também monitora) e a Zulmira lendo jornal. Toda contente, a Jane diz que agora não usa mais a boca para ler. Agora ela lê apenas com os olhos. Então, a Zulmira começou a contar sobre o poder que a leitura exercia sobre as pessoas, muito mais até que terapias, e encontros com psicólogos, segundo ela. E ela foi contando a sua história, a história do seu filho que esteve como interno do $C A S A^{59}$, antiga FEBEM. Quando esteve lá - hoje ele está em liberdade -, começou a se interessar por livros e descobriu um que chamou particularmente sua atenção: A arte da guerra. A Zulmira conta que, a princípio, ficou preocupada com o que poderia acontecer. Então, pediu ao filho que lhe contasse como era o livro, uma vez que ela mesma não o conhecia. Ele disse que se tratava de um livro voltado para estratégias e que para realizá-las era necessária à presença do estrategista, do intelectual e tinha também o burro... A Zulmira diz ao filho que ele era o burro. Ele se surpreende com a fala de sua mãe e ela explica:

- Você é o burro porque não sabe montar um plano pra sua vida, vive nas mãos dos outros... Então por que você não faz algo? Por que você não é o estrategista?

${ }^{59}$ Centro de Atendimento Socioeducativo ao Adolescente 
Apesar de Zulmira não ter lido o livro, por meio do diálogo, viabilizou a apropriação dessa leitura ao seu filho, atuando na zona proximal de que fala Vygotsky:

- A ficha dele caiu. Ele entendeu o que deveria fazer e fez. E este é um dos motivos pelo qual não está mais lá. Os dirigentes da Fundação vendo ele com aquele livro nas mãos o tempo todo, conversando com outros internos sobre ele, resolveram confiscar o livro com receio de algum tipo de rebelião.

Essa última fala da Zulmira faz recordar o que um promotor de justiça certa vez disse, ou questionou:

- Se apropriar da informação para quê? Que tipo de informação é essa? O que esses menores vão fazer com a informação que estão recebendo? O protagonismo deles poderá ser aquele não esperado.

Sem dúvida, em tais processos, o papel dos mediadores é essencial. Zulmira foi peça chave nos destinos das informações obtidas por seu filho. Sua presença de espírito, sua inteligência, sua disponibilidade, ao se encontrarem, ao serem negociadas com as experiências do filho, criaram uma dinâmica capaz de construir novos quadros cognitivos, novos modos de inserção, de atuação do filho no mundo em que vive, novos modos de ser, tanto para ela quanto para ele.

\subsubsection{Os Mediadores de leitura da Biblioteca Pública}

Na Biblioteca Pública Municipal, encontramos uma pessoa que, talvez por já manter um contato com as crianças e com os adolescentes do abrigo, foi desde o início uma figura chave para as atividades que lá ocorriam, facilitando tanto o empréstimo de livros como mediando o acervo literário, por meio de inúmeras atividades.

A relação com essa mediadora foi se desenvolvendo paulatinamente, à medida da das solicitações e das necessidades das crianças. Nesse sentido, algumas carências do espaço pouco favorável foram acentuadas. Tal dado demonstra como as inter-relações, as ações dos sujeitos alteram e reconfiguram espaços, tempos e ações - e a eles próprios. 
Alguns diálogos originados no abrigo ou no percurso eram continuados e alimentados nesse espaço, a partir de outros atores que entravam em cena, sejam outros atendentes ou mesmo outras pessoas e crianças que estavam por ali. Antes de sairmos do abrigo em direção à biblioteca, a Joyce veio devolver um livro da mala: Balanceia meu batalhão. Então, Rafael disse que a irmã dele estava no livro. Ele reconheceu a irmã numa foto onde aparece uma Congada Verde, manifestação folclórica do município, durante encontro de congadeiros. A questão da congada e da foto remeteu a uma conversa com Seu Dito, responsável pela Biblioteca Publica Municipal. Os acontecimentos e os sujeitos vão criando novos sentidos para o espaço, em função das dinâmicas ali desenvolvidas. E, nesse sentido, a disponibilidade para o diálogo é força capaz de até superar limites evidentes como os encontrados na Biblioteca Pública Municipal e seus problemas de infra-estrutura que necessitam ser, sem nenhuma dúvida, de providências importantes para serem corrigidos.

\subsubsection{O mediador/pesquisador}

Como não poderia deixar de ser, o mediador/pesquisador atua em dois campos:

a) No local onde a pesquisa se realiza. Nesse caso, participamos diretamente das atividades, idealizando e realizando as oficinas de leitura em conjunto com os demais mediadores do abrigo e as crianças. Uma das psicólogas diz sobre um comentário que um dos meninos fizera sobre o trabalho do mediador.

- Ele não entende por que você vem aqui, conta histórias, leva à Biblioteca, se não é contratada, se não recebe para ir lá. Por que vem aqui, se ninguém chamou, se ninguém foi atrás...

A Psicóloga disse ao garoto que o mediador havia chegado ali, naquele dia de chuva, procurando um local para abrir uma mala e contar as histórias. Ela diz a ele que o mediador fazia isso porque gostava.

A entrada no abrigo deu-se de uma maneira ficcional: uma viajante necessitando de um lugar para ficar. Mas, com o decorrer das oficinas, as crianças começaram a perceber que havia um envolvimento real, emocional, em função principalmente de se 
tratar de um trabalho que levava em consideração a presença de cada um. Nessas considerações e envolvimentos o mediador não era apenas personagem, mas ele próprio protagonista em interlocuções que o constituíam, assim como os demais atores participantes das oficinas de leitura.

- Hoje, Tia, eu não vou falar nada, eu quero muito um livro, mas você deve me dizer o que devo levar, então vamos ver se você sabe do que gosto.

Ao requerer do mediador uma atitude como a descrita acima, o adolescente está abrindo possibilidades e revelando desejos de conhecimentos mútuos. Um diálogo de qualidade profunda começa a ser desencadeado, a partir das negociações de repertórios de diferentes naturezas.

Interessante observar aqui que a oficina de leitura realizada sob o viés da dialogia presenteia o mediador pesquisador com o surpreendente. Por não haver um objeto a ser conquistado, mas explorações de universos onde seres humanos se relacionam das mais variadas formas, temos uma dinâmica que não depende de uma posição, um ponto de vista, mas da disponibilidade para a pluralidade de sentidos e de significações que acabam por causar uma expectativa em relação ao que acontecerá depois:

Portando a mala de histórias, a cada dia seguíamos pensativas em direção ao abrigo:

- Como será o dia hoje, na oficina?

\section{Polifonia}

Ter uma história em relação à leitura é ter uma história permeada de significados que encontram ressonâncias, ecos em outras vozes, sejam aquelas do texto escrito ou aquelas que estão presentes na prosa e na poesia do cotidiano. O mundo é polifônico, nele imperam vozes, consciências em interações e, como salienta Bakhtin, uma pluralidade de vozes não-fundidas, o que quer dizer que: “[...] Mesmo quando concordam, como podem fazê-lo, fazem em perspectivas diferentes e em diferentes percepções do mundo.” (MORSON, 2008, p. 253). 
Ora, interagir com o outro, de maneira dialógica, significa não se perder nessa interação, nem tampouco desejar e atuar visando a perda do outro. Os mundos de cada um são salvaguardados na medida das percepções, do reconhecimento do $e u$, do $t u$ e do isso, conforme ensinou Buber.

Mas de que maneira o discurso do mediador encontra o discurso das crianças e dos adolescentes? Quais linguagens permearam e tornaram as interações possíveis? Estas não são abstrações. São concretude, fenômenos que ocorrem no mundo físico e simbólico. Manifestam-se, portanto, por meio de e nos dispositivos.

Assim sendo, a roupa, a voz, a mala, os livros que o mediador utilizou vestiram os dispositivos, negociaram com os recursos trazidos pelos atores do local, compondo um o contexto cultural novo, de natureza dialógica.

Ao fazerem uso de recursos comuns, as mediações reduziam, assim, os desníveis do terreno comunicacional. Esses procedimentos são necessários, facilitam e viabilizam encontros: "[...] Alguns enunciados exigem que o falante e o ouvinte tenham o mesmo campo de visão, atitudes muito semelhantes e informações essencialmente idênticas. [...]" (MORSON, 2008, p. 219).

Tal afirmação não quer dizer que o contrário seja sempre inadequado, que encontros não possam acontecer também a partir de universos diferenciados, mas que é importante transitar entre um campo e outro, criar elos entre pontos eleitos para a comunicação se efetivar.

Ao me verem, algumas crianças já foram dizendo:

- Não deixa ela entrar;

-É, manda ela embora!

Ao ouvir isso, eu disse:

- Tudo bem, eu vou, é que trago comigo muitas histórias, mas...

O mas contrapõe e adiciona o discurso do outro, traz em si distinções e condições de articulações entre universos. E, nesse caso, resultou em uma abertura ao diálogo. 
Eu ia respondendo e misturando minha história com as histórias da mala e eles ouviam tudo de olhos abertos, prestando muita atenção, ao final perguntei se poderia voltar, ao que eles responderam que sim, então deixei alguns livros com eles...

O termo polifonia provém dos estudos de Bakhtin e, embora ele não o tenha definido claramente, podemos nos aproximar, através de seus estudos, um pouco do que viria a ser este conceito. Assim, colocamos este estudo exploratório como sendo polifônico na medida em que o autor "[...] prepara um palco para as contestações que ele não predestinou a vencer e cujo resultado não previu. [...] ele próprio participa desse dialogo. É um dos interlocutores 'no grande dialogo' que ele próprio criou." (MORSON, 2008, p. 255). Parafraseando: o mediador/pesquisador é aquele que prepara o palco, ou seja, as oficinas de leitura e se coloca ai também como interlocutor, sem saber exatamente o desencadeamento dessas.

[...] O verdadeiro dialogismo encarnara um mundo cuja unidade é essencialmente uma unidade de vozes múltiplas, cujas conversações nunca chegam a finalidade nem podem ser transcritas numa forma monológica. A unidade do mundo aparecerá como realmente é: polifônica. (MORSON, 2008, p. 79).

Ao trabalhar com a literatura infantil e juvenil colocamos em cena universos que estão vinculados ao plano simbólico cujas fronteiras conversam com experiências trazidas nos repertórios de cada um. Portanto, temos os repertórios constituídos dentro de uma polifonia, dentro de uma multiplicidade de consciências e pluralidade de vozes. Assim é quando se lê um livro, assim é quando interagimos com outras pessoas. Buscamos em nossas experiências vozes e as expressamos em discursos abertos a respostas. Respostas que vêm pela fala ou pela ação do outro ou de mim mesmo quando o pensar se dobra sobre si próprio.

Uma adolescente conta um pouco da sua história e as razões de estar no abrigo. Sua história, semelhante a tantas outras de crianças na mesma situação, aguarda por uma solução judicial. Ela lê o livro escrito por Esmeralda Ortiz, ex-menina de rua, Esmeralda, porque não dancei. Num diálogo intenso, carregado de signos convergentes e divergentes, as vozes do escritor e do leitor encontram-se, abrindo possibilidades de não finalização. O futuro não está completamente talhado pelo abrigo. O diálogo é capaz de produzir fendas e alimentar esperanças. 
Se é possível fugir do determinismo estreito e acreditar em possibilidades de transformação e superação via mediações dialógicas que confiram reconhecimento e identidade aos sujeitos participantes dos processos institucionais, é preciso, todavia, reconhecer que as práticas de leitura levadas a efeito por nós no abrigo partiram da compreensão de que a dialogia no contexto tratado dependia do reconhecimento de cada em sua especificidade e singularidade. Tal percepção nos levou à realização de ações envolvendo tanto grupos numericamente maiores como duplas e crianças tomadas individualmente. Se o reconhecimento do outro não é uma questão simples de quantidade, por outro lado, o número interfere, sem nenhuma dúvida, na qualidade das relações, caso extrapole a capacidade de atentarmos para as características, demandas e expectativas e interesses de cada um. Assim chegamos à idéia-semente que alimenta este trabalho: a da singularização, compreendendo-a como categoria intrínseca que alimenta e é alimentada pela dialogia. 


\section{CONSIDERAÇÕES FINAIS:}

\section{Dialogia e singularização}

Ao chegarmos às considerações finais, para não irmos na contramão da dialogia, não diríamos que chegamos ao final, mas a pontos de intersecção, a vias, cruzamentos, estradas que indicam caminhos e paisagens múltiplas - a direção do outro,

O que queremos ressaltar aqui é que, enquanto seres históricos que somos, temos nossas vidas mediadas pelas linguagens, pelos objetos, enfim, por um conjunto de elementos naturais e culturais, dispostos no tempo e no espaço, à espera de olhares que os atualizem em significados e em ações. Somos e nos constituídos como singularidade em relação com o mundo e sua diversidade. Nesse sentido, somos também plurais: eu, $t u$, isso, como quer Buber.

A idéia de congregar colaborativamente elementos de diferentes naturezas (teoria e prática), nesta pesquisa, permitiu emergirem algumas alternativas a uma questão educacional e cultural fundamental, envolvendo crianças e jovens em geral, mas especialmente, aquelas que estão em situação de abrigo: como mediar oficinas de leitura nestes contextos, de maneira a que o processo seja significativo para os participantes.

A colaboratividade, o método dialógico de mediação foi, portanto, importante e decisiva para que tais atividades se realizassem com resultados expostos ao longo deste trabalho. Evidentemente, houve diversas conversas e negociações para se chegar a acordos, bem como aos resultados. Assim, os relacionamentos e as interações foram se estabelecendo em diálogos ora mais simples, ora mais complexos, problematizando o conceito de dialogia, aproximando-o tanto da cooperação, como das tensões e conflitos próprios e inevitáveis do viver.

Mais uma questão surge e merece reflexão: a mediação cultural dialógica é um conceito de ordem puramente teórica ou é um conceito que se define somente em relação a um contexto concreto? Nosso trabalho indica que a dialogia é categoria situacional, ou seja, que se define em relação às situações em que se apresenta. O que é dialogia em certos contextos, poderá não ser, em outros. A análise dos dados segundo 
as variáveis dos ambientes, das ações, do tempo, dos protagonistas e da polifonia, mostram a força que os contextos exercem nos processos de construção de sentidos.

Ao realizarmos as oficinas de leitura para crianças e adolescentes no Abrigo "Lar Provisório", práticas comuns de mediação cultural se confrontaram com realidades particulares, chamando-nos a atenção. E, quando de dentro do grupo homogêneo particularidades saltam aos olhos, não há como fechá-los. Essa percepção nos leva em direção ao outro. Nesse encontro, na presentidade das ações, significados são construídos e proporcionam um sentido tanto para a ação como para seus protagonistas. Nesse interagir nos vinculamos. E como não nos vincularmos?

A presente pesquisa chamou nossa atenção para essa relação: os elos que, queiramos ou não, se estabelecem, de uma maneira ou de outra. Ou seja, desde o inicio, as oficinas de leitura no abrigo colocam a questão da vinculação mediador/pesquisador de um lado, crianças e jovens, de outro. Criar ou não vínculos (como se houvesse escolha) talvez seja questão de modalidade e não de natureza. Que vínculos são esses, eis efetivamente a questão?

Este trabalho tentou buscar respostas a essa questão. Ou seja, procuramos trabalhar oficinas de leitura que pudessem ser significativas para as crianças e que, apesar de implicarem forte vinculação entre mediadores e crianças, marcava-se também pelo critério da autonomia e do protagonismo cultural dos participantes. Em decorrência, foi dada particular importância a grupos pequenos, parcerias que permitissem uma aproximação maior que as observadas em grupos grandes, sem deixar de considerar também a importância dos grupos maiores. Interessava-nos o estabelecimento de relações significativas entre sujeitos, partilhadas a partir de interesses comuns, mas capazes de dialogar com a diferença.

Tais questionamentos e encaminhamentos nos levaram, assim, a perceber que, no abrigo escolhido para esta pesquisa, mais que mediar leitura, está em questão a realização de uma atividade cultural que requer disponibilidade para os participantes, olho no olho, face a face. Se o conceito de dialogia atuou na redefinição do espaçotempo institucional, este definiu, também, os caminhos das mediações, configurando-as segundo exigências apresentadas pela situação e, que, significam antes de mais nada, o reconhecimento do outro como sujeito, como pessoa única e inconfundível, como protagonista cultural. 
Ao desenvolvermos as oficinas de leitura num terreno particular, estávamos contextualizando a mediação cultural, logo, estávamos explorando o conceito de dialogia em situação. Deparamo-nos, então, com peculiaridades do abrigo que demonstraram a importância da singularizaão como categoria teórico-metodológica constitutiva da dialogia, abrindo-lhe caminhos e expandindo-a em direções contrárias à impessoalidade e à massificação, Nesses termos, o contexto não é instrumento, mas sim substância constitutiva do conceito de dialogia. Este se define em relação aos elementos e aos modos como eles estão posicionados e funcionam. Os quadros concretos definem, assim, a dialogia e a singularização e vice-versa.

Ao considerarmos os modos como os elementos constitutivos dos dispositivos são agenciados, percebemos a importância de procedimentos metodológicos que permitiam a singularização das crianças e dos adolescentes, especialmente em quadros marcados pela monologia e pelo transmissivismo, como os dos abrigos. Também observamos a importância do estranhamento, do deslocamento dos sentidos, das rotas de fuga. Os deslocamentos representam uma ruptura de significados pré-estabelecidos, que já estão dados e que se repetem monotonamente nas instituições. A partir deles, os processos vão ganhando novos significados, ressignificando os diferentes elementos no aqui e agora das ações.

Assim sendo, se a mediação cultural dialógica é um processo que se constitui na ação, é também um processo de construção de sentidos aberto às surpreendências. Para se constituir e manter, necessita ser permanentemente alimentado e retroalimentado com atos e palavras que produzam espantos e reconheçam os sujeitos em suas diferenças e singularidades. A singularização mostra-se, assim, como um modo de agir implícito aos atos dialógicos, deles se alimentando e, ao mesmo tempo, sendo por eles alimentada. Nesse sentido, podemos dizer que a mediação cultural dialógica, mais que um método, é atitude diante do outro, modo de ser e de estar no mundo, de constituir e se constituir. 


\section{Referências}

AMORIM, Marília. O pesquisador e seu outro: Bakhtin nas ciências humanas. São Paulo: Musa, 2001.

AURÉLIO. Dicionário da língua portuguesa. São Paulo: Nova Fronteira, 1975.

ARENDT, Hannah. A condição humana. 10. ed. Rio de Janeiro: Forense Universitária, 2008.

A crise na educação. In: Entre o

passado e o futuro. 6. ed. São Paulo: Perspectiva, 2007. p. 221-247.

BAJARD, Élie. Caminhos da escrita: espaços de aprendizagem. 2. ed. São Paulo: Cortez, 2002.

BAKHTIN, Mikhail Mikhailovich. Marxismo e filosofia da linguagem: problemas fundamentais do método sociológico na ciência da linguagem. São Paulo: Hucitec, 1981.

BARRETO, ALDO DE ALBUQUERQUE. A condição da informação. São Paulo Perspec. São Paulo, v. 16, n. 3, 2002. Disponível em: $<$ http://www.scielo.br/scielo.php?script=sci arttext\&pid=S0102-

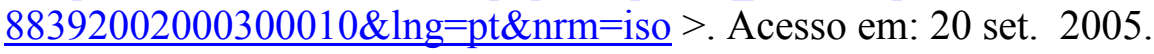

BARTHES, Roland. Aula. São Paulo: Cultrix, 1988.

BAUDRILLARD, Jean. O sistema dos objetos. São Paulo: Perspectiva, 1993.

BOSI, Ecléa. Memória e sociedade: lembranças de velhos. 4. ed. São Paulo: companhia das letras, 1994.

BOURDIEU, Pierre. Os três estados do capital cultural. In: Escritos de educação. 3. ed. Petrópolis: Vozes, 1998.

BRASIL. Estatuto da criança e do adolescente (1990): Lei n. 8.069, de 13 de julho de 1990, Lei n. 8.242, de 12 de outubro de 1991. 3. ed. Brasília: Câmara dos Deputados, Coordenação de Publicações, 2001. Disponível em: $<$ http://www.planalto.gov.br/ccivil_03/Leis/L8069.htm>. Acesso em: 23 jul. 2005.

. Lei 9.394, de 20 de dezembro de 1996 de Diretrizes e Bases da Educação Nacional. In: Portal MEC. Disponível em: $<$ http://portal.mec.gov.br/seed/arquivos/pdf/tvescola/leis/lein9394.pdf $>$ Acesso em: 06 ago. 2005. 
Plano nacional de promoção, proteção e defesa do direito da criança e adolescente à convivência familiar e comunitária. Brasília: Conselho Nacional de Assistência Social, 2006.

BRUNNER, Jerome. A cultura da educação. Porto Alegre: Artmed, 2001. . Atos de significação. Porto Alegre: Artes Médicas, 1997.

BUBER, Martin. Do dialogo e do dialógico. São Paulo: Perspectiva, 2007 . Eu e tu. 2. ed. rev. São Paulo: Cortez e Moraes, 1979.

CALDIN, Clarice Fortkamp. A leitura como função terapêutica: biblioterapia. Disponível em: <http://www.encontros-bibli.usfc.br/Edicao $>$ Acesso em: 17 abr. 2004.

CENTRO DE CAPACITAÇÃO E INCENTIVO À FORMAÇÃO. 101 perguntas e respostas sobre abandono e institucionalização. São Paulo: CeCiF, 2002.

CERTEAU, Michel. de. A invenção do cotidiano. Petrópolis: Vozes, 1994.

CHARLOT, Bernard. Da relação com o saber: elementos para uma teoria. Porto Alegre: Artmed, 2000.

COELHO, Teixeira. Dicionário crítico de política cultural: cultural e imaginário. 3. ed. São Paulo: Iluminuras, 2004.

CRESWELL, John W. Projeto de pesquisa: métodos qualitativos, quantitativos e mistos. 2. ed. Porto Alegre: Artmed, 2007.

CRIPPA, Giulia. Os "lugares da memória": dispositivos ideológicos, esquemas tópicos e sistemas classificatórios. In: LARA, Marilda; FUJINO, Asa; NORONHA, Dayse Pires (Org.). Informação e contemporaneidade: perspectivas. Recife: Néctar, 2007. p. 121-138.

CUTOLO, Giovanni. A abertura de obra aberta. In: ECO, Umberto. Obra aberta. São Paulo: Perspectiva, 2005, p. 07-13.

DALARI, Dalmo de Abreu; KORCZAK, Janusz. Direito da criança ao respeito. 3.ed. São Paulo: Summus, 1986.

DELEUZE, Gilles. Foucault. São Paulo: Brasilense, 2006.

DESGAGNÉ, Serge. Le concept de recherche collaborative: l'idée d'um raprochement entre chercheurs universitaires et praticiens enseignants. Érudit, Revue des sciences de l'éducation. v. 23, n. 2, 1997. p. 371-393. Disponível em: $<$ http://id.erudit.otg/iderudit/031921ar $>$ Acesso em: 25 nov.2008.

ECO, Umberto. Obra aberta. São Paulo: Perspectiva, 2005. 
FARACO, Carlos Alberto; CRISTOVÃO TEZZA, Gilberto de Castro (orgs) Diálogos com Bakhtin. Curitiba: UFPR, 1996.

FERRARA, Lucrécia D'Aléssio. A linguagem dialógica: da teoria à pratica. In: . A estratégia dos signos: linguagem, espaço, ambiente urbano. São

Paulo: Perspectiva, 1981.

FERREIRA, Jairo. Midiatização: dispositivos sociais e de comunicação. In Compôs. São Leopolodo, 2007. Disponível em: < http://www.compos.org.br/seer/index.php/ecompos/article/viewFile/196/197> Acesso em: 08 abr 2009.

FERRERO, Emilia. Cultura, escrita e educação. Rio de Janeiro: Artmed, 2000.

FOUCAMBERT, Jean. A leitura em questão. Porto Alegre: Artes médicas, 1994.

FOUCAULT, Michel. A hermenêutica do sujeito: curso dado no Collège de France (1981-1982). São Paulo: Martins Fontes, 2006.

FREIRE, Paulo. Pedagogia do oprimido. Montevidéu: Terra Nova, 1990.

GUIRADO, Marlene. Instituição e relações afetivas: o vínculo com o abandono. São Paulo: Casa do Psicólogo, 2004.

HARVEY, David. Condição pós-moderna. 15. ed. São Paulo: Loyola, 2006.

LE DISPOSITIF: entre usage et concept. Hermes. Paris, n.25, set. 1999. Disponível em:

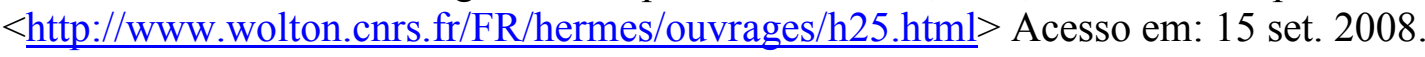

JACOBY, Sissa (org). A criança e a produção cultural: do brinquedo à literatura. Porto Alegre: Mercado Aberto, 2003.

MAKARENKO, A. S. Poema pedagógico. São Paulo: Brasilense, 1986, v.1-3.

MANGUEL, Alberto. Uma história da leitura. São Paulo: Companhia das Letras, 1997.

MARLEU-PONTY, Maurice. Fenomenologia da percepção. São Paulo: Martins Fontes, 1994.

MEDINA, Cremilda (org). Caminhos do saber plural: dez anos de trajetória. São Paulo: ECA/USP, 1999.

MIRANDA, Maria Irene. Conceitos centrais da teoria de Vygotsky e a prática pedagógica. In: Ensino em Re-Vista, 13(1): 7-28, jul.04/jul.05. Disponível em: http://www.emrevista.faced.ufu.br/include/getdoc.php?id=54\&article=11\&mode=pdf. Acesso em: 15 mai. 2009.

MORIN, Edgar. Ciência com consciência. 9. ed. Rio de Janeiro: Bertrand Brasil, 2005.

MORA, Jose Ferrater. Dicionário de filosofia. 4. ed. Lisboa: Dom Quixote, 1978. 
MORSON, Gary Saul; EMERSON, Caryl. Mikhail Bakhtin: criação de uma prosaística. São Paulo: EDUSP, 2008.

MONTESQUIEU. Essai sur lê goût. Paris: Rivage Poche, 1993.

ORTIZ, Esmeralda do Carmo. Por que não dancei. São Paulo: Atica, 2001.

ORTIZ, Renato. Legitimidade e estilos de vida. In: Mudialização e cultura. São Paulo: Brasiliense, 1994.

PELLANDA, Nize Maria Campos. Leitura como processo cognitivo complexo. In: OLMI, Alba; PERKOSKI, Noberto. Leitura e cognição: uma abordagem transdisciplinar. Santa Cruz do Sul: EDUNISC, 2005.

PERAYA, Daniel. (s.d.) Das mídias aos campus virtuais: um quadro de análise dos dispositivos de formação e de comunicação midiatizadas. Genéve: TECFA - Université de, Suisse. (tradução de Jairo Ferreira - Unisinos).

Le cyiberespace: un dispositif de communication et de formation médiatisées. In: ALAVA, S. (org) Ciberespace et autoformation, Porto Alegre: Artmed, 2002. p. 25-52.

PERROTTI, Edmir. Confinamento cultural: infầcia e leitura. São Paulo: Summus Editorial, 1990.

- Leitura. In: COELHO, Teixeira. Dicionário crítico de política cultural: cultural e imaginário. 3. ed. São Paulo: Iluminuras, 2004.

PERROTTI, Edmir; PIERUCCINI, Ivete. Infoeducação: saberes e fazeres da contemporaneidade. In: LARA, M.; FUJINO, A.; NORONHA, D. P. (Org.). Informação e contemporaneidade: perspectivas. Recife: Néctar, 2007. p. 47-96.

PETIT, Michèle. Os jovens e a leitura: uma nova perspectiva. São Paulo: 34, 2008.

PICHON-RIVIERÉ, Enrique. Teoria do vínculo. São Paulo: Martins Fontes, 2000.

PIERUCCINI, Ivete. A ordem informacional dialógica: estudo sobre a busca de informação em educação. 2004. 232 f. Tese (Doutorado em Ciência da Informação) Escola de Comunicações e Artes, Universidade de São Paulo, São Paulo, 2004.

PROUST, Marcel. Sobre a leitura. Campinas: Pontes, 1991.

RANDON, Michel, et al. La pensée transdisciplinaire et le réel, Dervy, Paris, 1996.

RODRIGUES, Adriano Duarte. Dicionário breve da informação e da comunicação. Lisboa: Presença, 2000.

SALABERRIA, Ramón. Entrevista a Michele Petit, antropóloga, investigadora de la lectura. Imaginaria: revista quincenal sobre literatua infantil y juvenil. abr. 2000, no. 
23. Disponível em $<$ http://www.imaginaria.com.ar/02/3/petit.htm $>$ Acesso em: 25 mar. 2007.

SCHWARTZ, Gilson. Laboratórios de emancipação digital: pesquisa-programa-ação em colaboratórios da Cidade do Conhecimento. In: UNIrevista. São Leopoldo, jul. 2006. Disponível em: <http://www.unirevista.unisinos.br/_pdf/UNIrev_Schwartz.PDF> Acesso em: 08 abr. 2009.

SILVA, Enid Rocha da; MELLO, Simone Gueresi de. Contextualizando o Levantamento nacional dos abrigos para crianças e adolescentes da rede de serviços de ação continuada. In: PEA. Disponível em: $<\underline{\text { http://www.ipea.gov.br/sites/000/2/livros/direitoconvivenciafamiliar/capit1.pdf }>}$ Acesso em: 10 set. 2008.

SOUZA NETO, João Clemente de. O abrigo como amparo para o sonho. São Paulo: Arte impressa, 2001.

SUASSUNA, Ariano. Iniciação a estética. 7. ed. Rio de Janeiro: José Olympio, 2005.

VALVERDE, Monclar. (org.) As formas do sentido: estudos em estética da comunicação. Rio de Janeiro: DP\&A, 2003.

VIGOTSKI, Lev Semenovitch. Pensamento e linguagem. 4. ed. São Paulo: Martins Fontes, 2008.

VYGOTSKY, Lev Semenovitch. A Formação social da mente: o desenvolvimento dos processos psicológicos superiores. 6. ed. São Paulo: Martins Fontes, 2002.

WITKOSK, Antônio Carlos. Diversidade intelectual e a cultura política: abordagem gramsciana. São Paulo: Anna Blume, 2000.

WILLIAMS, Raymond. Cultura. 2. ed. Rio de Janeiro: Paz e Terra, 2000.

Paulo: Boitempo, 2007. . Palavras-chave: um vocabulário de cultura e sociedade. São 
Anexos 


\section{Anexo 1}

O CeCIF - Centro de Capacitação e Incentivo à Formação de profissionais, voluntários e organizações que desenvolvem trabalho de apoio à convivência familiar - considera as seguintes modalidades e tipos de abrigos:

1. Abrigos de curta permanência
a) casas de passagem
b) albergues
c) comunidades terapêuticas
d) casas de crianças com câncer
e) casas transitórias
f) casas de crianças com deficiência física e/ou mental

2. Abrigos de permanência prolongada
a) orfanatos
b) internatos
c) educandários
d) casas-lares
e) aldeias

O abrigo no qual se realizou essa pesquisa pertence à segunda modalidade, é um abrigo de permanência prolongada do tipo casa-lar, porém sem a figura da mãe social. 
Anexo 2

CONSULTAS E CURSOS

\begin{tabular}{|c|c|c|c|c|c|c|c|}
\hline \multicolumn{8}{|c|}{ Segunda-feira } \\
\hline TAMARA & \multicolumn{2}{|c|}{ Psicólogo } & \multicolumn{2}{|c|}{ Dra. Marilda } & \multicolumn{2}{|l|}{ Ao lado da Cherry } & 09:00h \\
\hline DAVID & \multicolumn{2}{|c|}{ Psicólogo } & \multicolumn{2}{|c|}{ Dra.Madalena } & \multicolumn{2}{|l|}{ Posto de saúde } & 10:00h \\
\hline EDUARDO & \multicolumn{2}{|c|}{ Psicólogo } & \multicolumn{2}{|c|}{ Dra. Daniela } & \multicolumn{2}{|l|}{ Posto de saúde } & $13: 00 \mathrm{~h}$ \\
\hline MAURO & \multicolumn{2}{|c|}{ Psicólogo } & \multicolumn{2}{|c|}{ Dra.Madalena } & \multicolumn{2}{|l|}{ Posto de saúde } & $13: 30 \mathrm{~h}$ \\
\hline SENDY & \multicolumn{2}{|c|}{ Psicólogo } & \multicolumn{2}{|c|}{ Dra. Daniela } & \multicolumn{2}{|l|}{ Posto de saúde } & $13: 50 \mathrm{~h}$ \\
\hline DANIEL & \multicolumn{2}{|c|}{ Fisioterapia } & & \multicolumn{2}{|l|}{ APAE } & $14: 45 \mathrm{~h}$ \\
\hline MARIA & \multicolumn{2}{|c|}{ Infoeducação } & \multicolumn{2}{|c|}{ Sônia } & \multicolumn{2}{|l|}{ Abrigo/Biblioteca } & $\begin{array}{l}14 \mathrm{~h} \text { às } \\
15 \mathrm{~h}\end{array}$ \\
\hline MAURO/SÉRGIO & \multicolumn{2}{|c|}{ Infoeducação } & \multicolumn{2}{|c|}{ Sônia } & \multicolumn{2}{|l|}{ Abrigo/Biblioteca } & $\begin{array}{l}16 \mathrm{~h} \text { às } \\
17 \mathrm{~h}\end{array}$ \\
\hline FELIPE/DANIEL & \multicolumn{2}{|c|}{ Infoeducação } & \multicolumn{2}{|c|}{ Sônia } & Abrigo/Bibliotec & & $\begin{array}{l}17 \mathrm{~h} \text { às } \\
18 \mathrm{~h}\end{array}$ \\
\hline & & & Terç & a-feira & & & \\
\hline $\begin{array}{l}\text { TAMARA E } \\
\text { CÉLIA }\end{array}$ & $\begin{array}{l}\text { Aula } \\
\text { e de b }\end{array}$ & $\begin{array}{l}\text { le teatro } \\
\text { juteria }\end{array}$ & Mar & iely & CRAS & & $3: 00 \mathrm{~h}$ \\
\hline CÉLIA & Fono: & udióloga & Dra. & & Posto de saúde & & $: 40 \mathrm{~h}$ \\
\hline DANIEL & Psicó & oga & Dra. & Daniele & Posto de Saúde & & :30h \\
\hline & RUPO & COM AS & PSIC & ÓLOGAS & & & :30h \\
\hline & & & uar & a-feira & & & \\
\hline CÉSAR/CÉLIA & & Infoeduc & ção & Sônia & Abrigo/Bibliot & eca & $8 \mathrm{~h}$ às $9 \mathrm{~h}$ \\
\hline ÉRICA & & Infoeduc & ção & Sônia & Abrigo/Bibliot & eca & $\begin{array}{l}9 \mathrm{~h} \text { às } \\
10 \mathrm{~h}\end{array}$ \\
\hline TAMARA & & Ação Jov & & Mariely & C.R.A.S. & & 08:00h \\
\hline $\mathrm{CAIO}$ & & Basquete & & & EMBASA & & $14: 00 \mathrm{~h}$ \\
\hline SENDY & & Psicólog & & Dra.Dan & \begin{tabular}{l|l} 
ela & Posto de saúde
\end{tabular} & & $14: 50 \mathrm{~h}$ \\
\hline EDUARDO/CAIO/D & NILO & Infoeduc & ção & Sônia & Abrigo/Bibliot & eca & $\begin{array}{l}17 \mathrm{~h} \text { às } \\
18 \mathrm{~h}\end{array}$ \\
\hline TAMARA/JÉSSIC & & Infoeduc & ção & Sônia & Abrigo/Bibliot & eca & $\begin{array}{l}18 \mathrm{~h} \text { às } \\
19 \mathrm{~h}\end{array}$ \\
\hline & & & uin & a-feira & & & \\
\hline DANILO & Psicó & oga & Dra. & Marilda & Ao lado da Cherry & & $4: 00 \mathrm{~h}$ \\
\hline EDUARDO & Futeb & & & & EMBASA & & $4: 00 \mathrm{~h}$ \\
\hline DANILO & Futeb & & & & EMBASA & & $6: 00 \mathrm{~h}$ \\
\hline & & & Sex & t-feira & & & \\
\hline TAMARA & Basqu & & & & EMBASA & & $: 00 \mathrm{~h}$ \\
\hline CAIO & Psicó & oga & Dra. & Daniele & Posto de saúde & & $00 \mathrm{~h}$ \\
\hline EDUARDO & Basq & & & & EMBASA & & $: 00 \mathrm{~h}$ \\
\hline & & & Sál & ado & & & \\
\hline TAMARA & Cateq & dese & & & Salão Paroquial & & $30 \mathrm{~h} / 11: 00 \mathrm{~h}$ \\
\hline Todos & Infoec & ucação & Sôni & & $\begin{array}{l}\text { Abrigo/Parque } \\
\text { Ecológico/outro }\end{array}$ & & $\begin{array}{l}\mathrm{h} \text { às } 17 \mathrm{~h} \\
\text { rário a } \\
\text { nbinar } \mathrm{c} / \\
\text { sana) }\end{array}$ \\
\hline & & & Do & ingo & & & \\
\hline EDUARDO/CAIO & Catec & uese & & & Thomaz & 08: & $: 00 \mathrm{~h} / 9: 30 \mathrm{~h}$ \\
\hline
\end{tabular}

